\title{
Catalytic Tuning of Sorption Kinetics of Lightweight Hydrides: A Review of the Materials and Mechanism
}

\author{
Ankur Jain ${ }^{1, *}$, Shivani Agarwal ${ }^{2}$ and Takayuki Ichikawa ${ }^{3, *}$
}

1 Natural Science Centre for Basic Research \& Development, Hiroshima University, Higashihiroshima 739-8530, Japan

2 Department of Physics, JECRC University, Jaipur 303905, India; shivaniphy@gmail.com

3 Graduate School of Engineering, Hiroshima University, Higashihiroshima 739-8527, Japan

* Correspondence: ankur.j.ankur@gmail.com or ankur@hiroshima-u.ac.jp (A.J.); tichi@hiroshima-u.ac.jp (T.I.); Tel.: +81-82-424-4609 (A.J.); +81-82-424-5744 (T.I.)

Received: 31 October 2018; Accepted: 5 December 2018; Published: 11 December 2018

\begin{abstract}
Hydrogen storage materials have been a subject of intensive research during the last 4 decades. Several developments have been achieved in regard of finding suitable materials as per the US-DOE targets. While the lightweight metal hydrides and complex hydrides meet the targeted hydrogen capacity, these possess difficulties of hard thermodynamics and sluggish kinetics of hydrogen sorption. A number of methods have been explored to tune the thermodynamic and kinetic properties of these materials. The thermodynamic constraints could be resolved using an intermediate step of alloying or by making reactive composites with other hydrogen storage materials, whereas the sluggish kinetics could be improved using several approaches such as downsizing and the use of catalysts. The catalyst addition reduces the activation barrier and enhances the sorption rate of hydrogen absorption/desorption. In this review, the catalytic modifications of lightweight hydrogen storage materials are reported and the mechanism towards the improvement is discussed.
\end{abstract}

Keywords: hydrogen storage materials; metal hydrides; magnesium hydride; complex hydrides; alanates; borohydrides; amides

\section{Outline}

1. Introduction

2. The mechanism of Hydrogen Absorption/Desorption and the Need for a Catalyst

3. Catalysts for $\mathrm{MgH}_{2}$

3.1 Transition Metal Catalysts

3.2 Carbon and Other Elements as Additive

3.3 Metal Oxide Catalysts

3.4 Metal Halide Catalysts

3.5 Hydride, Hydride Forming Alloys and Sulfide as Catalyst

4. Catalysts for Complex Hydrides

4.1 Catalysts for Alanates

4.2 Catalysts for Borohydrides

4.3 Catalysts for Amides

4.4 Catalysts for Silanides

5. Concluding Remarks and Future Prospective

References

\section{Introduction}

Hydrogen is considered as an alternative fuel which has the capability to replace current fossil fuel based energy infrastructure. It is important to note that hydrogen is not a primary energy source; 
it can store, transport, and deliver the energy. In contrast to fossil fuels such as gasoline, diesel, etc. which emit greenhouse gases, it emits only water as byproduct when converted to electrical energy. The gravimetric energy content of hydrogen is $2-3$ times higher than conventional fuels, however, the volumetric energy density is quite low in comparison to conventional fuels [1]. It needs more than twice the space in liquid state as compared to the space required by gasoline for a car to run 300 miles. The amount is increased to 3-5 times for the compressed state with 10,000 psi and 5000 psi tanks. Moreover, the need for bulky and expensive tanks, low temperature of liquefaction, and the safety issues with both of the above options renders them impractical for commercial application. Thus, the third method of hydrogen storage through solid state materials has attracted the attention of the scientific community as it reduces the required storage pressure as well as increases the gravimetric and volumetric capacity significantly. Thus, hydrogen storage in solid state through the physically or chemically bounded form in the material has been a subject of various studies in last few decades [2-6]. Several materials / families have been developed in search of suitable material having a target operating temperature of $-40{ }^{\circ} \mathrm{C}-85^{\circ} \mathrm{C}$ and storage capacity of $>8 \mathrm{wt} \%$ respectively as per US-DOE [7], which are summarized in Table 1 [8-16].

Table 1. Hydrogen storage families with their storage capacities and operating temperatures.

\begin{tabular}{|c|c|c|}
\hline Materials & Storage Capacity & Operating Temperature \\
\hline $\begin{array}{l}\text { Sorbent Systems [8] } \\
\text { Hydrogen is attached to the surface via physisorptionEx.-C-based } \\
\text { materials, MOFs }\end{array}$ & $2-7 w t \%$ & $\sim 77 \mathrm{~K}$ \\
\hline $\begin{array}{l}\text { Conventional metal hydrides [9-11] } \\
\text { Hydrogen forms various bonds with metal atoms. } \\
\text { - Interstitial Hydrides } \\
\text { Ex.- } \mathrm{LaNi}_{5}, \text { FeTi etc } \\
\text { Ionic/covalent hydride } \\
\text { Ex.- } \mathrm{LiH}, \mathrm{MgH}_{2} \text { etc. }\end{array}$ & $\begin{array}{l}1 \sim 4 \mathrm{wt} \% \\
>7 \mathrm{wt} \%\end{array}$ & $\begin{aligned} & \mathrm{RT} \\
> & 600 \mathrm{~K}\end{aligned}$ \\
\hline $\begin{array}{l}\text { Complex Hydrides [12,13] } \\
\text { Hydrogen covalently bonded and the formed anion complex is } \\
\text { bonded with cation via ionic bond } \\
\text { Alanates (Ex.- } \mathrm{LiAlH} \mathrm{H}_{4}, \mathrm{NaAlH}_{4}, \mathrm{Mg}\left(\mathrm{AlH}_{4}\right)_{2} \text { etc.) } \\
\text { Borohydrides }\left(\mathrm{Ex} .-\mathrm{LiBH}_{4}, \mathrm{NaBH}_{4}, \mathrm{Mg}\left(\mathrm{BH}_{4}\right)_{2} \text { etc.) }\right. \\
\text { Amides (Ex.- }-\mathrm{LiNH}_{2}, \mathrm{NaNH}_{2}, \mathrm{Mg}\left(\mathrm{NH}_{2}\right)_{2} \text { etc.) } \\
\left.\text { Silanides (Ex.- }-\mathrm{KSiH}_{3}, \mathrm{RbSiH}_{3}, \mathrm{CsSiH}\right)\end{array}$ & $\begin{array}{l}5.8 \sim 10.5 \mathrm{wt} \% \\
10 \sim 18.5 \mathrm{wt} \% \\
5 \sim 10 \mathrm{wt} \% \\
2 \sim 4.5 \mathrm{wt} \%\end{array}$ & $\begin{array}{l}\geq 400 \mathrm{~K} \\
\geq 400 \mathrm{~K} \\
\geq 400 \mathrm{~K} \\
\mathrm{RT} \sim 500 \mathrm{~K}\end{array}$ \\
\hline $\begin{array}{l}\text { Chemical Hydrides }[14,15] \\
\text { Hydrogen is covalently bonded and these materials are irreversible } \\
\text { Ex.- } \mathrm{NH}_{3}, \mathrm{NH}_{3} \mathrm{BH}_{3}\end{array}$ & $17.8 \sim 20 \mathrm{wt} \%$ & $373 \sim>773 \mathrm{~K}$ \\
\hline $\begin{array}{l}\text { Liquid Organic Materials [16] } \\
\text { Ex.-methylcyclohexane-toluene-hydrogen (MTH cycle), } \\
\text { Cyclohexane-benzene-hydrogen (CBH cycle) etc. }\end{array}$ & $\sim 6-7 \mathrm{wt} \%$ & $500 \sim 750 \mathrm{~K}$ \\
\hline
\end{tabular}

It is clear that the sorbent systems are not capable of achieving the targeted capacity, moreover, they have very low operating temperature too. The conventional metal hydrides such as $\mathrm{LaNi}_{5}, \mathrm{FeTi}$, $\mathrm{V}-\mathrm{Ti}-\mathrm{Cr}$ etc., have been studied extensively. These could be employed for stationary applications such as hydrogen compressors [17], however, these cannot be employed for onboard applications due to their low gravimetric storage capacity. The chemical hydrides have high capacity, but these are irreversible, thus, only suitable for a single use of hydrogen supply. Among all these, light hydrides such as $\mathrm{LiH}, \mathrm{MgH}_{2}$, and complex hydrides fit with high capacity of 7-18.5 wt\%. Although these light element based hydrides and complex hydrides have very high hydrogen capacity, they possess two serious issues at the same time. The first is the thermodynamic issue, which is caused by the presence of strong covalent/ionic bonds, thus making these hydrides very stable and requiring a high operating temperature $\left(>200^{\circ} \mathrm{C}\right)$. The thermodynamic destabilization can be achieved by two methods: one of which is downsizing the particles, however, it can be achieved only if the size is reduced to several nanometers, which is neither easy to achieve nor to maintain. Thus, the second 
approach of introducing an intermediate state (Figure 1) can solve this issue [18]. However, this is not in the scope of this article. Herein, we will review the second issue of slow kinetics of hydrogen sorption in light element hydrides/complex hydrides. The challenge of kinetics arises due to the highly directional nature of bonding present in these hydrides, which creates a large diffusion barrier leading to a prohibitively slow reaction rate for hydrogen charging-discharging. Several other factors also contribute to the kinetics problem, e.g., the dissociation of $\mathrm{H}_{2}$ molecule to atomic $\mathrm{H}$, etc. In the next section, we will explain the mechanism of hydrogen absorption and desorption in terms of its kinetics.

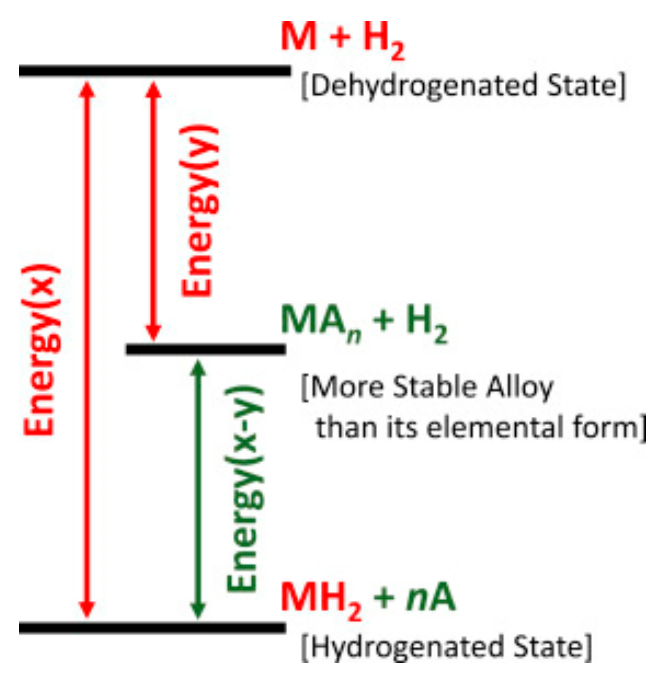

Figure 1. Schematic of destabilization process of a hydride MH using third element A. Adapted with permission from [18], copyright Elsevier, 2016.

\section{The Mechanism of Hydrogen Absorption/Desorption and the Need of Catalyst}

The kinetics of hydrogen sorption is defined as the rate of hydrogen absorption and desorption by a particular metal or alloy, and is equally as important and decisive a factor as thermodynamics. While the thermodynamics is represented by enthalpy of formation $(\Delta \mathrm{H})$ and entropy $(\Delta \mathrm{S})$ of hydride, the kinetics is usually represented by activation energy (E) of the reaction. The activation energy of sorption reaction can be calculated by Arrhenius Equation (1) and Kissinger Equation (2) as follows:

$$
\begin{gathered}
\mathrm{K}=\mathrm{A} \exp \left[-\mathrm{E}_{\mathrm{a}} / \mathrm{RT}\right] \\
\ln \left(\beta / \mathrm{T}_{\mathrm{p}}{ }^{2}\right)=\ln \left(\mathrm{AR} / \mathrm{E}_{\mathrm{a}}\right)-\mathrm{E}_{\mathrm{a}} /\left(\mathrm{RT}_{\mathrm{p}}\right)
\end{gathered}
$$

where $E_{a}$ is activation energy, $k$ is rate constant, $A$ is frequency factor, $R$ is gas constant, $T$ is temperature, $\beta$ is heating rate, and $T p$ is peak temperature.

The kinetics of hydrogen sorption is influenced by several factors such as the diffusion coefficient of $\mathrm{H}_{2}$, the occurrence of phase transition, the heat of solution, and the intrinsic rate of $\mathrm{H}_{2}$ transfer through solid-gas interface, etc. [19]. This can be understood on the basis of a hydrogen absorption-desorption mechanism as mentioned by Martin et al. [20]. The hydrogen is stored in the metal/alloys through the following 5 processes as shown in Figure 2:

1. Physisorption of $\mathrm{H}_{2}$ molecule;

2. Chemisorption of $\mathrm{H}$ atoms;

3. Surface penetration of $\mathrm{H}$ atoms;

4. Diffusion of hydrogen atoms;

5. Hydride formation at metal/hydride interface. 

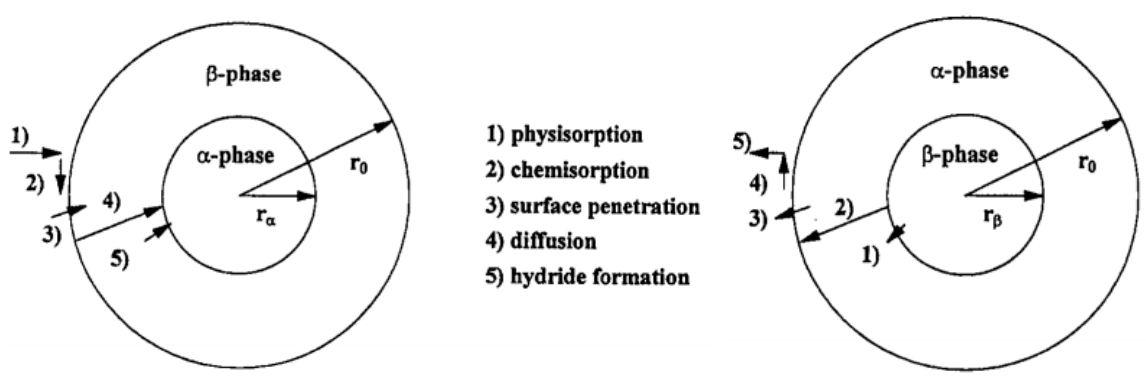

1) hydride decomposition

2) diffusion

3) surface penetration

4) recombination

5) desorption to gas phase

Figure 2. Reaction partial steps for the absorption (left) and desorption (right) of hydrogen by a spherical metal/hydride powder particle. Adapted with the permission from [20], copyright Elsevier, 2016.

One of these steps is considered as a rate limiting step for a particular reaction and the other steps are in equilibrium. Since the physisorption of $\mathrm{H}_{2}$ molecule need almost no activation energy, it is not a rate limiting step. The concentration of $\mathrm{H}_{2}$ molecules impinged on the surface of metal is directly proportional to the applied pressure. All other steps can be rate-limiting steps and affect the kinetics of hydrogen sorption. The desorption reaction follows the same steps but in a reverse direction as shown in Figure 2.

Several methods have been proposed for reducing the activation barrier and enhancing the kinetics of hydrogen sorption. These include nano-scaling and use of catalysts [21-24]. Some researchers also include alloying as a tool of altering the kinetics [24], however, in our opinion alloying mainly affects the thermodynamics of a system. In fact, alloying changes the entire path of hydrogen sorption of a metal/alloy. By forming thermodynamically more stable alloys (Figure 1), the operating temperature can be reduced effectively, but it is not really a kinetic alteration. Thus, only downsizing and use of catalysts should be considered as kinetics enhancement tools, where only the activation barrier is altered without affecting the thermodynamics as shown in Figure 3.

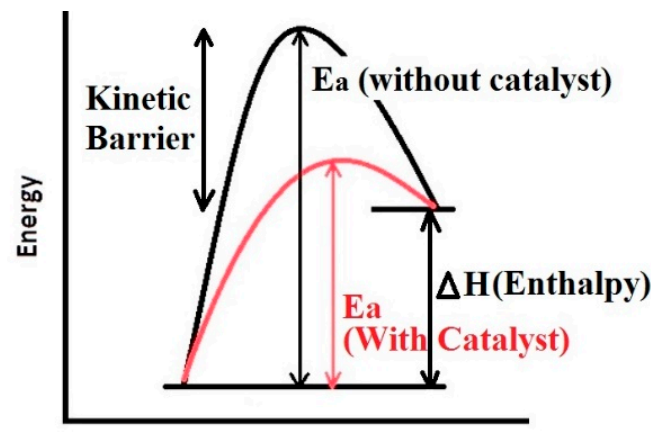

Figure 3. Representation of the kinetic barrier of the reaction and lowering the activation Energy $\left(\mathrm{E}_{\mathrm{a}}\right)$ using catalyst.

Downsizing to nano-scale has been considered as an effective method to improve the sorption kinetics. As mentioned above, the kinetics depends on the activation barrier involved with the chemisorption of $\mathrm{H}$ atoms on the metal surface, diffusion of hydrogen atoms, or nucleation of the hydride phase, thus, nano-scaling can accelerate the kinetics through the creation of fresh surface for chemisorption, decreased diffusion distance for $\mathrm{H}$ atoms, and increased surface to volume ratio, thus providing more nucleation sites for hydride formation [25-27]. For example, it has been shown that $\mathrm{MgH}_{2}$ nanowires show a much lower energy barrier $\left(\sim 33.5-38.8 \mathrm{~kJ} \mathrm{~mol}^{-1}\right)$ than bulk $\mathrm{MgH}_{2}$ $\left(120-142 \mathrm{~kJ} \mathrm{~mol}^{-1}\right)$ [28]. It is noteworthy that the nanosizing down to $<50 \mathrm{~nm}$ can enhance the kinetics, whereas the size $<5 \mathrm{~nm}$ can alter the thermodynamics of $\mathrm{MgH}_{2}$ as well [25]. In spite of the outstanding performance of the nano-sizing, it cannot be used for practical applications, especially because of two issues: (1) The preparation of such small sized structure is not easy on commercial/industry level, 
(2) The cyclic stability of these nano-structures is not good as these agglomerates during the sorption cycles and they lose their benefits of nano-size. The approach of using a catalyst to enhance the kinetics has a benefit over nano-sizing as it is easy to prepare in comparison to nano-sizing and shows even better performance over it. A catalyst is defined as a material which enhances the sorption rate of a metal/alloy without participating into the chemical reaction and reducing the activation barrier only. In some cases, a catalyst can also participate in the chemical reaction, but remains intact at the end of reaction. Until now, several catalysts have been developed for different hydrogen storage materials, which will be reviewed in the next section in accordance with respective hydrogen storage materials.

\section{Catalysts for $\mathrm{MgH}_{2}$}

Magnesium hydride $\left(\mathrm{MgH}_{2}\right)$ has been an attractive contender for hydrogen storage due to its high hydrogen content $(7.6 \mathrm{wt} \%)$. It can be formed directly through the reaction of magnesium with hydrogen under mild conditions thermodynamically $\left(<1\right.$ bar and $\left.\sim 50{ }^{\circ} \mathrm{C}\right)$, however, the sluggish kinetics allow the hydrogenation to occur only at $350-400{ }^{\circ} \mathrm{C}$ and high pressure, i.e., $3 \mathrm{MPa}$ [29-31]. There are several factors which affect the kinetics of magnesium hydride formation, including the surface oxidation [32], low dissociation rate of $\mathrm{H}_{2}$ molecules on metal surface [33], and slow diffusion of dissociated $\mathrm{H}_{2}$ atoms within the hydride [34]. Even if the surface oxide layer is broken the through activation process, it takes several hours to form $\mathrm{MgH}_{2}$ at $>350{ }^{\circ} \mathrm{C}$. And, even if the initial hydrogenation is somehow fast enough due to high pressure, the formation of a hydride layer on the surface blocks further penetration of hydrogen $[35,36]$. It is reported that a $30-50 \mu \mathrm{m}$ thick hydride layer can stop further hydrogenation abruptly [32,37]. Thus bulk $\mathrm{MgH}_{2}$ cannot be used practically due to the above mentioned reasons and needs to be modified for its sorption kinetics using catalysts. The present section will describe different types of additives, used to improve the sorption kinetics of $\mathrm{MgH}_{2}$.

\subsection{Transition Metal Catalysts}

Since, the dissociation of $\mathrm{H}_{2}$ molecules and diffusion of hydrogen atoms through the metal are two rate limiting steps for $\mathrm{H}_{2}$ absorption in $\mathrm{Mg}$, several theoretical studies have been conducted to analyze the hydrogen magnesium interaction in respect to the transition metal catalysts [38-42]. Kecik et al. [38] used the first principle molecular dynamics method for the calculation of adsorption energies of $\mathrm{Mo}, \mathrm{Nb}, \mathrm{Mn}, \mathrm{Cr}, \mathrm{Co}, \mathrm{Fe}, \mathrm{V}, \mathrm{Pd}$, and $\mathrm{Ni}$ on a magnesium surface and suggested that the transition metals including and to the left of the VI-A column tend to be adsorbed on a substitutional site while other transition elements have a tendency to be adsorbed on a bridge site. In addition to this, they also found that the transition metals having a higher chance of adsorption are also capable of causing dissociation of the hydrogen molecule. According to this, all $3 \mathrm{~d}$ and $4 \mathrm{~d}$ transition metals should work as effective catalysts, however, it is not always the case with experiments. Slow kinetics is still a problem with many of the transition metals, which can be understood on the basis of DFT calculations carried by Pozzo et al. [39]. They suggested that all the transition metals show two opposite catalytic activities at the same time; the metals effective for the dissociation do not have any effect for the diffusion and vice versa. It can be well understood from Figure 4 . The activation energy barrier for $\mathrm{H}_{2}$ dissociation and diffusion strongly correlates with the d-band center. It is clear that except for $\mathrm{Ag}, \mathrm{Cu}$, and $\mathrm{Pd}$, all other metals have a very low dissociation barrier, however, at the same time they have a large diffusion barrier. On the other hand, $\mathrm{Ag}, \mathrm{Cu}$, and $\mathrm{Pd}$ do not bind the $\mathrm{H}$ atoms too strongly and, therefore, have almost no diffusion barrier, but at the same time they do not have any effect on the dissociation of $\mathrm{H}_{2}$ molecule. This suggests that $\mathrm{Ni}, \mathrm{Fe}, \mathrm{Rh}$, and $\mathrm{Pd}$ have the best possible catalytic activity with a good balance in overcoming the diffusion barrier and dissociation barrier at the same time. The above theoretical findings are well supported by several experimental works, which were carried out during the $70 \mathrm{~s}$ to the $90 \mathrm{~s}$ of the last century, however, the operating temperature was still more than 330 or $350{ }^{\circ} \mathrm{C}$ for the $\mathrm{H}_{2}$ sorption by magnesium with sufficient rate and capacity. Zaluska et al. [43] were the first ones who prepared nano-crystalline $\mathrm{MgH}_{2}$ decorated 
with nano-particles of $\mathrm{Pd}$, as well as other metals such as $\mathrm{Fe}, \mathrm{V}$, and $\mathrm{Zr}$, and reduced the absorption temperature to less than $200{ }^{\circ} \mathrm{C}$ and desorption temperature to less than $280^{\circ} \mathrm{C}$. In a contemporary report, Liang et al. [44] ball milled a number of transition metals, i.e., $\mathrm{Ti}, \mathrm{V}, \mathrm{Mn}, \mathrm{Fe}$, and $\mathrm{Ni}$ and found the rapid desorption for $\mathrm{MgH}_{2}-\mathrm{V}$ followed by $\mathrm{Ti}, \mathrm{Fe}, \mathrm{Ni}$, and $\mathrm{Mn}$ at low temperatures, whereas $\mathrm{Ti}$ addition showed rapidest absorption followed by $\mathrm{V}, \mathrm{Fe}, \mathrm{Mn}$, and $\mathrm{Ni}$. In a later study [45] on $\mathrm{MgH}_{2}+$ $5 \mathrm{at} \% \mathrm{~V}$, they suggested that hydrogen desorption at high temperature is controlled by the interface motion. However, at low temperatures, where the driving force is small, the hydrogen desorption is first controlled by nucleation and growth followed by long range hydrogen diffusion. Reactive mechanical milling under $\mathrm{H}_{2}$ atmosphere has been found to be an effective method to enhance the $\mathrm{H}_{2}$ sorption properties of Mg. Bobet et al. [46] demonstrated that RMA for even a short time ( $2 \mathrm{~h})$ with Co, $\mathrm{Ni}$, and Fe improved the sorption properties of magnesium. A further improvement in the surface properties of $\mathrm{MgH}_{2}$ was achieved by the use of nano-sized metal catalysts such as $\mathrm{Pd}, \mathrm{Pt}, \mathrm{Ru}$ [47], $\mathrm{Fe}$, $\mathrm{Co}, \mathrm{Ni}, \mathrm{Cu}$ [48]. Hanada et al. [48] showed that the activation energy of desorption was reduced to $94 \pm 3 \mathrm{~kJ} \mathrm{~mol}^{-1}$ by the addition of $2 \mathrm{~mol} \%$ nano-Ni in comparison with the $323 \pm 40 \mathrm{~kJ} \mathrm{~mol}^{-1}$ for pure $\mathrm{MgH}_{2}$. The $\mathrm{MgH}_{2}-2 \%$ nano-Ni system desorbs a large amount of $\mathrm{H}_{2}(0.5 \mathrm{wt} \%)$ in the temperature range of $150-200{ }^{\circ} \mathrm{C}$ under He flow (Figure 5).

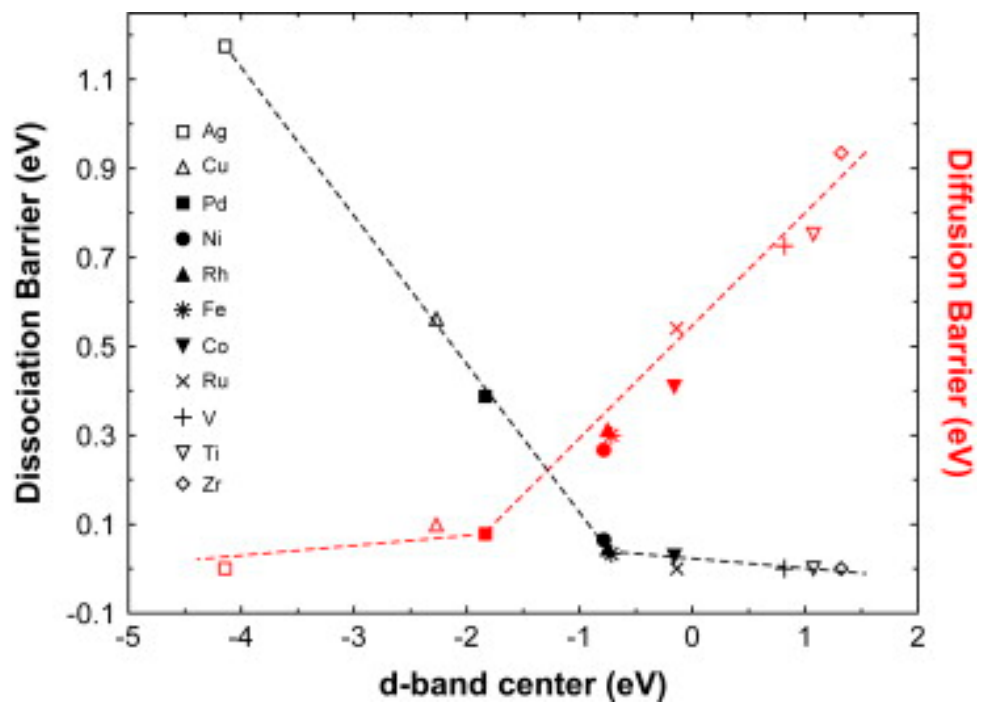

Figure 4. Activation energy barrier for hydrogen dissociation (black) and diffusion (red) of hydrogen on pure $\mathrm{Mg}$ and metal-doped $\mathrm{Mg}$ surfaces as a function of d-band center positions. Adapted with the permission from [39], copyright Elsevier, 2009.

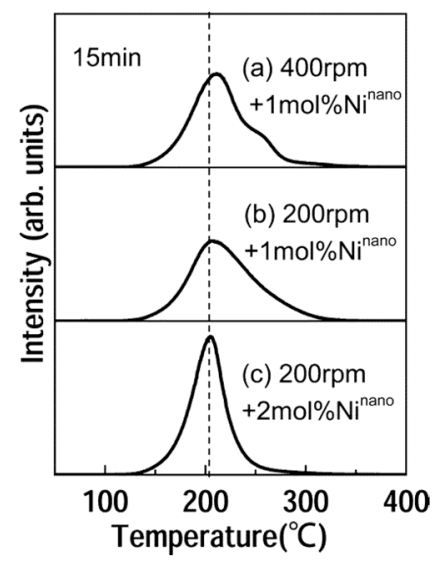

Figure 5. Thermal desorption mass spectra of hydrogen for the $\mathrm{MgH}_{2}$ composites milled for $15 \mathrm{~min}$ at (a) $400 \mathrm{rpm}$ with $1 \mathrm{~mol} \% \mathrm{Ni}^{\text {nano }}$, (b) $200 \mathrm{rpm}$ with $1 \mathrm{~mol} \% \mathrm{Ni}^{\text {nano }}$, and (c) $200 \mathrm{rpm}$ with $2 \mathrm{~mol} \%$ $\mathrm{Ni}^{\text {nano }}$, respectively. Adapted with the permission from [48], copyright ACS, 2005. 
Following the above reports, several efforts have been devoted to improve the sorption properties of $\mathrm{MgH}_{2}$ using different nano-transition metals in different amount, prepared by different routes etc. [49,50], however, nano-Ni has always shown superior performance among them [51-54]. Recently Chen et al. [53] prepared a composite of porous Ni nano-fibers via electrospinning technique and prepared a composite of these with $\mathrm{MgH}_{2}$ using ball milling. The resulting composite has shown an activation energy of $81.5 \mathrm{~kJ} \mathrm{~mol}^{-1}$ with the onset desorption temperature of $143{ }^{\circ} \mathrm{C}$. Lu et al. [55] prepared a novel core-shell structured $\mathrm{Mg}-\mathrm{TM}(\mathrm{TM}=\mathrm{Co}, \mathrm{V})$ composite through a combined arc plasma and electroless plating method. The ternary $\mathrm{Mg}-\mathrm{Co}-\mathrm{V}$ composite has shown a much lower activation energy $\left(E_{a}=67.66 \mathrm{~kJ} \mathrm{~mol}^{-1}\right)$ in comparison with other binary composites or pure $\mathrm{MgH}_{2}$.

\subsection{Carbon and Other Elements as Additive}

Besides transition metals as catalysts, several other elements have also been studied to modify the kinetics of magnesium hydride. Carbon structures are one of the most studied systems as composite materials with $\mathrm{MgH}_{2}$. Imamura et al. [56], in 2003, focused on the composite of graphite and magnesium prepared by mechanical milling in the presence of organic additives. According to them, the dangling bonds of carbon, produced by high energy milling, act as hydrogen accommodating sites. The hydrogen uptake by the $\mathrm{Mg}$ increased in the order of additive benzene, cyclohexene, and cyclohexane. It was observed that the addition of crystalline graphite had very little effect on the desorption properties, but lead to a rapid hydrogen absorption in comparison to pure $\mathrm{MgH}_{2}$ [57]. In addition, it formed a protective layer and inhibited the formation of oxide layer on Mg. Different species of carbon including graphite, activated carbon, multi-walled carbon nano-tubes, and carbon nano-fibers have shown great influence on the sorption properties of $\mathrm{MgH}_{2}$ in terms of lower desorption temperature and fast sorption kinetics [58-62]. Reactive ball milling under hydrogen atmosphere further enhances the effect of graphite/carbon addition [63,64]. Recently Lototsky et al. [64], using time resolved studies, showed that carbon acts as a carrier of activated hydrogen through spill-over mechanism. They suggested that high energy reactive ball milling destructs the original carbon structure and forms graphene layers, which encapsulate $\mathrm{MgH}_{2}$ nanoparticles and prevents the grain growth. This helps to keep the sorption cycling stability much better. Besides carbon material, rare earth metals have also shown positive effects on the sorption properties of $\mathrm{MgH}_{2}$ [65]. It is known that rare earth metals work as oxygen getters, so their presence reduces the possibility of the formation of surface oxide layer of $\mathrm{Mg}$, thus improving the sorption properties. Mainly La, Y and Ce metals (either in metallic form or hydride form) have been used as catalyst for $\mathrm{MgH}_{2}$ [66-68]. Shang et al. [66] showed that $\mathrm{Ce}$ addition improves desorption kinetics of $\mathrm{MgH}_{2}$, much better than the $\mathrm{Y}$ addition. It occured due to $\mathrm{CeO}_{2}$ formation, which produced surface defects on $\mathrm{MgH}_{2}$ benefiting the desorption kinetics. Recently, other rare earth elements such as $\mathrm{Nd}$, $\mathrm{Gd}$ and Er were also investigated as catalysts for $\mathrm{MgH}_{2}$ [69]. Zou et al. [69] prepared the Mg- $\mathrm{RE}$ nano composite through the arc plasma method with a special metal oxide type core-shell structure. The ultrafine $\mathrm{Mg}-\mathrm{RE}$ particles covered by nano-sized $\mathrm{MgO}$ and $\mathrm{Re}_{2} \mathrm{O}_{3}$ showed greatly enhanced kinetics as well as anti-oxidation properties of $\mathrm{MgH}_{2}$.

\subsection{Metal Oxide Catalysts}

In addition to metal based catalysts, several oxides such as $\mathrm{TiO}_{2}, \mathrm{~V}_{2} \mathrm{O}_{5}, \mathrm{Cr}_{2} \mathrm{O}_{3}, \mathrm{Mn}_{2} \mathrm{O}_{3}, \mathrm{Fe}_{3} \mathrm{O}_{4}$, $\mathrm{CuO}, \mathrm{Al}_{2} \mathrm{O}_{3}, \mathrm{SiO}_{2}, \mathrm{Sc}_{2} \mathrm{O}_{3}, \mathrm{CeO}_{2}, \mathrm{Nb}_{2} \mathrm{O}_{5}, \mathrm{ZnO}$, etc., [70-74] have shown enormous catalytic acceleration of hydrogen sorption properties of $\mathrm{MgH}_{2}$. Oelrich et al. [70], in a comparative study, depicted the comparable effects of $\mathrm{TiO}_{2}, \mathrm{~V}_{2} \mathrm{O}_{5}, \mathrm{Cr}_{2} \mathrm{O}_{3}, \mathrm{Mn}_{2} \mathrm{O}_{3}, \mathrm{Fe}_{3} \mathrm{O}_{4}$, and $\mathrm{CuO}$ on the absorption kinetics, whereas $\mathrm{Fe}_{3} \mathrm{O}_{4}$ lead $\mathrm{V}_{2} \mathrm{O}_{5}, \mathrm{Mn}_{2} \mathrm{O}_{3}, \mathrm{Cr}_{2} \mathrm{O}_{3}$, and $\mathrm{TiO}_{2}$ to improve the desorption kinetics. Later, in a systematic study on several high performance catalysts, Barkhordarian et al. [73] suggested that four different physico-thermodynamic properties of these catalysts influence the catalytic activity, namely, (1) a high number of structural defects, (2) the low stability of compound, (3) the high valence state of the transitional metal ion, (4) and high affinity of transition metal ion to hydrogen. On the basis of these 
factors, they summarized the catalysts according to their catalytic activity as shown in Figure 6. It is clear from the figure that $\mathrm{Nb}_{2} \mathrm{O}_{5}$ has the highest catalytic activity for the sorption properties of $\mathrm{MgH}_{2}$, which makes it one of the most studied catalyst in the hydrogen storage community [75-86]. In earlier studies, Barkhordarian et al. studied the effect of $\mathrm{Nb}_{2} \mathrm{O}_{5}$ content, milling time etc., on the sorption properties [75-77] and deduced that the rate limiting step is greatly influenced by the catalyst content. At lower temperatures, i.e., $250{ }^{\circ} \mathrm{C}$ and catalyst content up to $0.1 \mathrm{~mol} \%$, the reaction is 3-dimensional growth controlled due to slower diffusion (because of low temperature) as well as slow hydrogen draining and a longer diffusion path (because of lack of catalyst). With the same content of catalyst but at a higher temperature, i.e., $300{ }^{\circ} \mathrm{C}$, the reaction becomes surface controlled as the diffusion of hydrogen is easier at $300{ }^{\circ} \mathrm{C}$ and the reaction rate is only controlled by a slow gas-solid reaction due to low content of catalyst. When the catalyst amount is increased to $0.2 \mathrm{~mol} \%$ or more, the reaction is interface controlled because the recombination rate of hydrogen atoms is no longer a rate limiting step. The absorption is diffusion controlled, whereas, the rate limiting step for desorption changes from chemisorption to interface growth with the increase of milling time or $\mathrm{Nb}_{2} \mathrm{O}_{5}$ content [77] as shown in Figure 7.

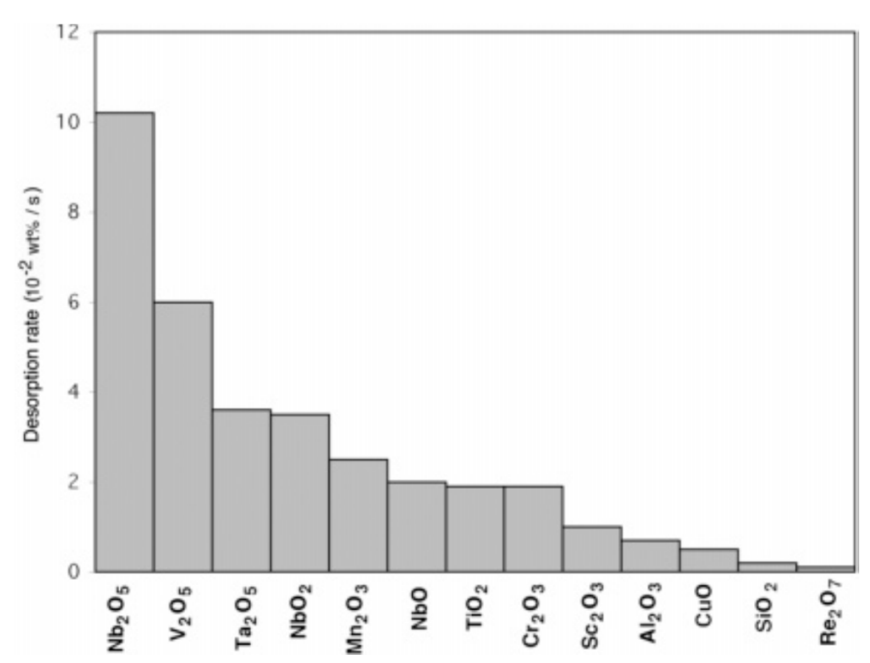

Figure 6. Various transition-metal oxides and their catalytic effect on the hydrogen desorption reaction rate of magnesium hydride at $300 \mathrm{C}$. Reaction rates were calculated between $20 \%$ and $80 \%$ of the respective maximum capacity. Adapted with the permission from [73], copyright ACS, 2006.
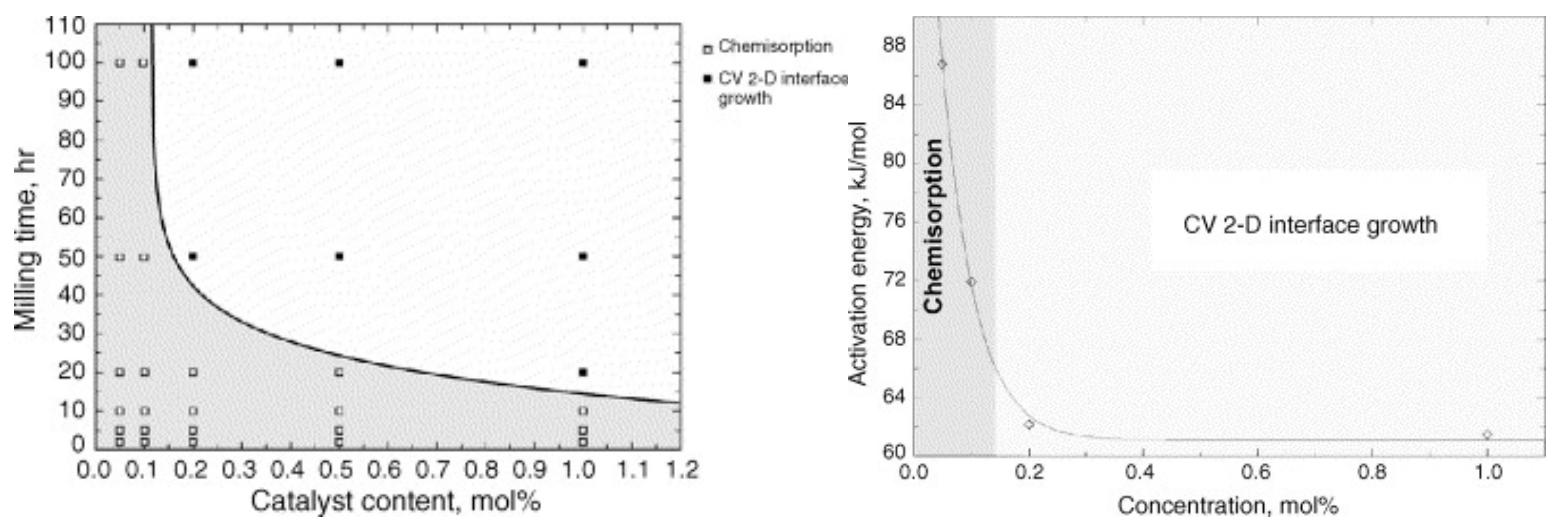

Figure 7. Kinetic rate-limiting step for desorption as a function of milling time and $\mathrm{Nb}_{2} \mathrm{O}_{5}$ concentration (left); Decrease of activation energy for the hydrogen desorption of magnesium hydride with different $\mathrm{Nb}_{2} \mathrm{O}_{5}$ catalyst contents milled for $100 \mathrm{~h}$ (right). Adapted with permission from [77], copyright Elsevier, 2006. 
While other attempts were focused on the sorption behavior at more than $200{ }^{\circ} \mathrm{C}$, the group of Ichikawa presented the room temperature absorption behavior of $\mathrm{Nb}_{2} \mathrm{O}_{5}$ catalyzed $\mathrm{Mg}$ [78-81]. They showed that the composite with $1 \mathrm{~mol} \% \mathrm{Nb}_{2} \mathrm{O}_{5}$ absorbs $4.5 \mathrm{wt} \% \mathrm{H}_{2}$ at $1 \mathrm{MPa}_{2}$ pressure within $15 \mathrm{~s}$ even at room temperature. A further improvement was achieved by the same group by using mesoporous $\mathrm{Nb}_{2} \mathrm{O}_{5}$ as a catalyst, where the absorption occurred at even $-50{ }^{\circ} \mathrm{C}$ with an activation energy of $70 \mathrm{~kJ} / \mathrm{mol} \mathrm{H}_{2}$ and $38 \mathrm{~kJ} / \mathrm{mol} \mathrm{H}_{2}$ for desorption and absorption respectively [80]. It was suggested that $\mathrm{Nb}_{2} \mathrm{O}_{5}$ was reduced to the oxides with lower oxidation state of $\mathrm{Nb}$, i.e., $\mathrm{NbO}$, which is responsible for the decrease in activation energy [81]. Another possible mechanism has been suggested by Friedrich et al. [82,83], where they proposed the formation of $\mathrm{MgNb}_{2} \mathrm{O}_{3.67}$ phase in addition to $\mathrm{Nb}$ and $\mathrm{MgO}$ during the first cycling of sorption. They suggested all these phases contribute to the kinetic enhancement of $\mathrm{MgH}_{2}$. Ma et al. [86] also confirmed the existence of above phases using TEM analysis and proposed the $\mathrm{Nb}$-gateway model where $\mathrm{Nb}$ facilitated the hydrogen transportation from $\mathrm{MgH}_{2}$ to outside. Inspired from the above study, Pukazhselvan et al. [87-89] prepared rock salt structured $\mathrm{Mg}_{\mathrm{x}} \mathrm{Nb}_{1-\mathrm{x}} \mathrm{O}$ nano-particles separately and suggested that it can catalyze $\mathrm{MgH}_{2}$ much better than in-situ formed $\mathrm{Mg}_{\mathrm{x}} \mathrm{Nb}_{1-\mathrm{x}} \mathrm{O}$ in $2 \mathrm{wt} \% \mathrm{Nb}_{2} \mathrm{O}_{5}$ catalyzed $\mathrm{MgH}_{2}$.

Several other transition metal oxides also have been subject of intensive research, especially V-oxide [90-92], $\mathrm{Cr}$ oxide [93-96], Ti oxide [97-99], $\mathrm{ZrO}_{2}$ [100] have shown promising effects in improving the kinetics of $\mathrm{MgH}_{2}$. Recently, rare earth metal oxides [101-104] have also attracted attention as catalysts for $\mathrm{MgH}_{2}$. In a recent study by Liu et al. [104], $\mathrm{CeO}_{2}$ was shown to have a dramatic catalysis capability toward $\mathrm{MgH}_{2}$ when mixed with $\mathrm{CeH}_{2.73}$ in 1:1 ratio and the hydrogen desorption could be started at temperature as low as $210^{\circ} \mathrm{C}$. Recently, a new class of catalysts emerged with potential catalytic effect, which are termed as complex metal oxides. These complex metal oxides are composed of two metals and oxygen such as $\mathrm{CoFe}_{2} \mathrm{O}_{4}$ [105], $\mathrm{NiFe}_{2} \mathrm{O}_{4}$ [106], $\mathrm{Co}_{2} \mathrm{NiO}$ [107], $\mathrm{SrFe}_{12} \mathrm{O}_{19}$ [108], $\mathrm{Li}_{2} \mathrm{TiO}_{3}$ [109], $\mathrm{MnFe}_{2} \mathrm{O}_{4}$ [110], $\mathrm{Na}_{2} \mathrm{Ti}_{3} \mathrm{O}_{7}$ [111], $\mathrm{BiVO}_{4}$ [112] etc. Some of these could reduce the desorption activation energy of $\mathrm{MgH}_{2}$ down to $70 \mathrm{~kJ} / \mathrm{mol} \mathrm{H}_{2}$ [111].

Recently, a different mechanism for catalytic behavior of oxides has been proposed [113], which is claimed to have more generalized coverage of all the oxides. The earlier hypothesis given by Klassen et al. [70,73] was more focused on transition metal oxides, which have defective oxide sites and high valence state metals capable of high electron exchange rate, thus are suitable for the sorption kinetics improvement. However, this model fails to describe the effects of $\mathrm{MgO}$ and other non-transition metal oxides. A tribological effect model has been proposed to explain the high catalytic activity of $\mathrm{MgO}$, almost comparable to that of $\mathrm{Nb}_{2} \mathrm{O}_{5}$, the best known catalyst. According to this model, a correlation between the desorption temperature and electronegativity of the oxide addition has been established and is shown in Figure 8. This correlation has been explained on the basis of a lower friction coefficient at the interface of solid oxides having higher electronegativity, which allows effective grinding process. This enhances the stabilization of small particles which can have fast sorption rate due to shorter diffusion path.

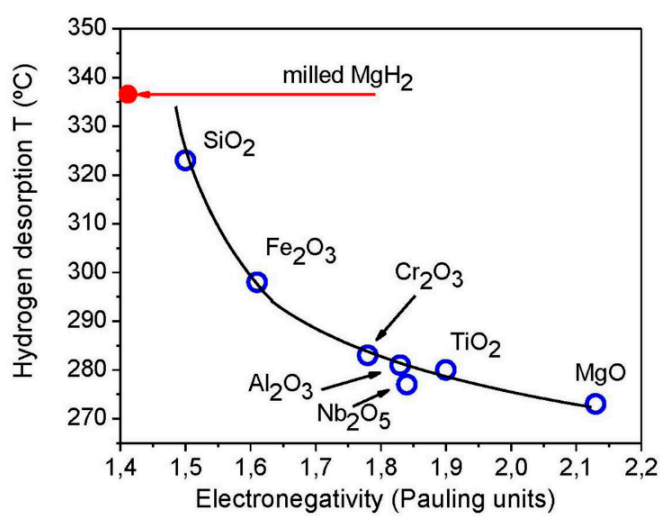

Figure 8. Correlation between the desorption temperature of hydrogen from $\mathrm{MgH}_{2}$ achieved upon oxide addition during milling and the electronegativity of the oxide additives. Adapted with the permission from [113], copyright MDPI, 2012. 


\subsection{Metal Halide Catalysts}

Metal halides having chloride and fluoride ion have been considered effective catalysts, even better than the metal or metal oxide. In a comparative study, Bhat et al. [114] suggested that $\mathrm{NbCl}_{5}$ addition shows much better catalytic effect than the well-known $\mathrm{Nb}_{2} \mathrm{O}_{5}$. Thus, they suggested that neither the oxide ion nor transition metal/transition metal cation are crucial, but it is the chemical nature/iconicity of catalyst which acts as a deciding factor. Malka et al. [115] studied 19 different chlorides and fluorides of different metals and concluded that fluorides are better catalysts than chlorides. In addition, they also suggested that halides with higher oxidation state are more effective in reducing the desorption temperature. As a conclusion of this work, it was stated that the halides of group IV and V, namely $\mathrm{ZrF}_{4}, \mathrm{TaF}_{5}, \mathrm{NbF}_{5}, \mathrm{VCl}_{3}$, and $\mathrm{TiCl}_{3}$ were more effective catalysts than other halides. In a later study, it was suggested that fluorides have higher catalytic activity because of the $\mathrm{MgF}_{2}$ formation in addition to transition metal, which itself acts as a catalyst and further improves the sorption kinetics [116,117]. Several chlorides i.e., $\mathrm{CrCl}_{3}$ [118], $\mathrm{NiCl}_{2}, \mathrm{CoCl}_{2}$ [119], $\mathrm{TiCl}_{3}$ [120], $\mathrm{FeCl}_{3}$ [121], $\mathrm{LaCl}_{3}$ [122], $\mathrm{CeCl}_{3}$ [123], $\mathrm{ZrCl}_{4}$ [124] etc., have been extensively studied, however, most of them could reduce the desorption activation energy only to more than $100 \mathrm{~kJ} / \mathrm{mol} \mathrm{H}_{2}$. A remarkable improvement was observed for $\mathrm{ZrCl}_{4}$ addition, where the reduction of $\mathrm{ZrCl}_{4}$ to $\mathrm{ZrCl}_{3}$ and $\mathrm{Zr}$ metal showed good catalytic effect and the desorption activation energy could be lowered to $92 \mathrm{~kJ} / \mathrm{mol} \mathrm{H}_{2}$. The catalyzed sample could be rehydrogenated even at $0{ }^{\circ} \mathrm{C}$ under moderate hydrogen pressure. The results of superior catalytic effect of fluorides on sorption kinetics of $\mathrm{MgH}_{2}$, lead to several comparison studies, mainly focused on the comparison between $\mathrm{TiF}_{3}$ and $\mathrm{TiCl}_{3}$ [125-127]. The XPS experiments [125,126] suggested the mechanism of superior catalytic effect of $\mathrm{TiF}_{3}$ over $\mathrm{TiCl}_{3}$. According to this, both samples react with $\mathrm{MgH}_{2}$ and form $\mathrm{TiH}_{2}$ as well as dead magnesium halides. However, $\mathrm{F}$ ions participate to generate $\mathrm{Mg}-\mathrm{Ti}-\mathrm{F}$ metastable species in addition to the formation of $\mathrm{MgF}_{2}$. This additional $\mathrm{Mg}-\mathrm{Ti}-\mathrm{F}$ species was found responsible for better catalytic activity of $\mathrm{TiF}_{3}$. Since in-situ formed $\mathrm{MgF}_{2}$ has been suggested as one of the responsible component for catalytic enhancement, Jain et al. [128] reported the effect of direct addition of $\mathrm{MgF}_{2}$ and found that it is beneficial for kinetic enhancement as well as cyclic stability, with low sensitivity to atmospheric conditions and easy handling. Inspired by the merits of $\mathrm{F}$ ions, several researchers have developed different fluoride materials such as $\mathrm{CeF}_{4}, \mathrm{NbF}_{5}, \mathrm{ZrF}_{4}$, $\mathrm{TiF}_{3}, \mathrm{TiF}_{4}$ etc. [129-133]. An assumption has been proposed on the basis of intermediate $\mathrm{H}^{\delta-}-\mathrm{Nb}^{\delta+}$ bond formation, which is favored by large electronic delocalization of the $\mathrm{Nb}-\mathrm{F}$ bond. This leads to the weakening of surface $\mathrm{Mg}^{\delta+}-\mathrm{H}^{\delta-}$ bonds. It also justifies the higher activity of $\mathrm{NbF}_{5}$ in comparison with $\mathrm{Nb}_{2} \mathrm{O}_{5}$, as the electronegativity of fluorine is greater than that of oxygen, which in turn produces more pronounced electronic delocalization for $\mathrm{F}$ than $\mathrm{O}$, thus increasing the weakening of $\mathrm{Mg}^{\delta+}-\mathrm{H}^{\delta-}$ bonds. Although all the fluorides have shown promising effects, they all were limited to bringing the activation energy down to $90 \mathrm{~kJ} / \mathrm{mol} \mathrm{H}_{2}$. A drastic improvement was achieved recently by the addition of $\mathrm{TiF}_{4}[132,133]$, where the activation energy could be reduced down to $70 \mathrm{~kJ} / \mathrm{mol} \mathrm{H}_{2}$. The onset desorption temperature could be reduced down to $150{ }^{\circ} \mathrm{C}$ in comparison to 300 and $400{ }^{\circ} \mathrm{C}$ for ball milled and as received $\mathrm{MgH}_{2}$, respectively, as shown in Figure 9 [132]. The XPS study [133] agrees well with the results of Ma et al. [125,126], which suggested that $\mathrm{Ti}^{4+}$ state is reduced to lower oxidation states i.e., $\mathrm{Ti}^{3+} / \mathrm{Ti}^{2+}$ and formed $\mathrm{TiH}_{2}$ in addition to $\mathrm{Ti}-\mathrm{Mg}-\mathrm{F}$ species. Inspired by the successful implementation of single metal fluorides, recently several binary metal complex fluorides namely $\mathrm{K}_{2} \mathrm{TiF}_{6}$ [134], $\mathrm{K}_{2} \mathrm{ZrF}_{6}$ [135], $\mathrm{K}_{2} \mathrm{NiF}_{6}$ [136], $\mathrm{Na}_{3} \mathrm{FeF}_{6}$ [137] etc. have been tested. The best performance was observed with the addition of $10 \% \mathrm{Na}_{3} \mathrm{FeF}_{6}$, which reduced the activation energy down to $75 \mathrm{~kJ} / \mathrm{mol} \mathrm{H}_{2}$. It was suggested that in-situ formation of $\mathrm{NaMgF}_{3}, \mathrm{NaF}$ and Fe play catalytic roles to improve the sorption kinetics of $\mathrm{MgH}_{2}$. A similar mechanism was also proposed for other complex fluorides. 


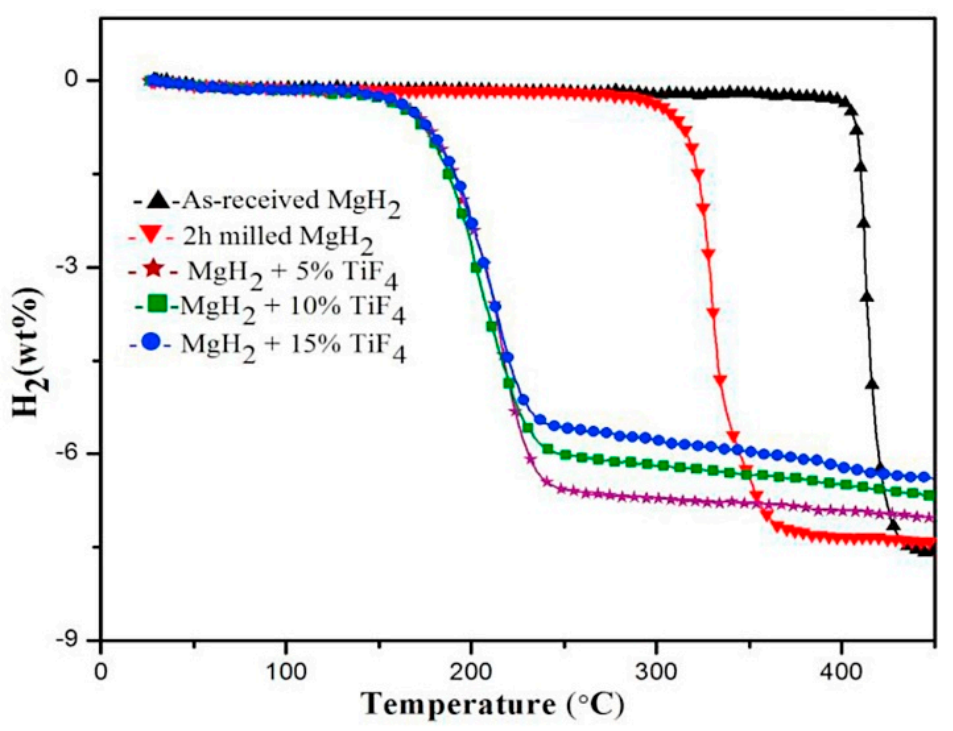

Figure 9. TG curve for dehydrogenation of the as-received $\mathrm{MgH}_{2}, 2 \mathrm{~h}$ milled $\mathrm{MgH}_{2}$, and $\mathrm{MgH}_{2-} \mathrm{x}$ wt $\%$ $\mathrm{TiF}_{4}(\mathrm{x}=5,10,15)$ samples. Adapted with the permission from [132], copyright Elsevier, 2016.

\subsection{Hydride, Hydride Forming Alloys and Sulfide as Catalyst}

The use of hydride materials as catalyst for $\mathrm{MgH}_{2}$ is led by $\mathrm{TiH}_{2}$ [138-144]. The mixture of $\mathrm{MgH}_{2}$ and $\mathrm{TiH}_{2}$ in 7:1 molar ratio, prepared through high energy high pressure mechanical milling, showed drastic improvement of $\mathrm{H}_{2}$ desorption kinetics and reduction in desorption temperature. The desorption onset temperature was reduced down to $126{ }^{\circ} \mathrm{C}$, much lower than $381{ }^{\circ} \mathrm{C}$ for $\mathrm{MgH}_{2}$ alone [138]. The activation energy was reduced down to $71 \mathrm{~kJ} / \mathrm{mol} \mathrm{H}_{2}$. In a later report, $\mathrm{Lu}$ et al. [139] prepared a nanosized $\mathrm{MgH}_{2}-0.1 \mathrm{TiH}_{2}$ system with a grain size of 5-10 nm. The transmission electron microscopy (TEM) study suggested uniform distribution of $\mathrm{TiH}_{2}$ among $\mathrm{MgH}_{2}$ particles, which, in addition to nano size, was an important factor for such a drastic improvement. They also reported a reduced $\Delta \mathrm{H}$ value $\left(-68 \mathrm{~kJ} / \mathrm{mol} \mathrm{H}_{2}\right)$ for this system, which is significantly lower than that of pure $\mathrm{MgH}_{2}$. It was also observed that this system can reabsorb hydrogen at room temperature with a significant rate and very stable cyclability $[139,140]$. Three different possibilities have been proposed for this catalytic property of $\mathrm{TiH}_{2}$ by considering $\mathrm{TiH}_{2}$ as (1) grain growth inhibitor (prevents coarsening of $\mathrm{MgH}_{2}$ particles); (2) nucleation and growth center $\left(\mathrm{TiH}_{2}\right.$ is non-stoichiometric compound and allows faster diffusion); (3) alloying or solid solution forming compound with $\mathrm{MgH}_{2}$ (since $\Delta \mathrm{H}$ and $\Delta \mathrm{S}$ values are different from those of $\mathrm{MgH}_{2}$ ). A theoretical and microscopic investigation on $\mathrm{MgH}_{2}-\mathrm{TiH}_{2}$ system [144] suggested TiH2 as a stable component during $\mathrm{H}_{2}$ absorption and desorption which acts as dynamic dopant, i.e., $\mathrm{TiH}_{2}$ particles are located on the top surface of $\mathrm{MgH}_{2}$, which then migrates to the subsurface during dehydrogenation as shown in Figure 10 [144]. Other hydrides for the catalysis of $\mathrm{MgH}_{2}$ sorption are $\mathrm{NbH}$ and $\mathrm{AlH}_{3}[145,146]$, however, they don't show any impressive improvement like $\mathrm{TiH}_{2}$.

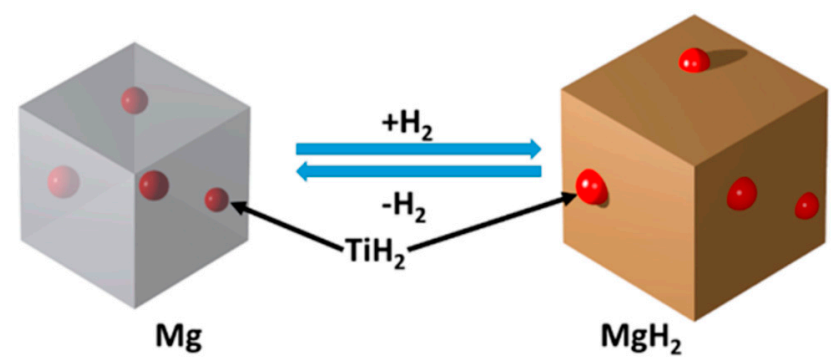

Figure 10. The catalytic mechanism of $\mathrm{TiH}_{2}$ as dynamic dopant. Adapted with the permission from [144], copyright ACS, 2018. 
In addition to metal hydrides, several complex hydrides also have been tried out as catalysts for $\mathrm{MgH}_{2}$ [147-153]. However, in our opinion, these systems work on the basis of chemical destabilization of $\mathrm{MgH}_{2}$ and thus alter the thermodynamics rather than altering kinetics. The next category of catalyst material is not very different from the hydride materials, the only difference being their use in an unhydrided state in contrast with $\mathrm{TiH}_{2}, \mathrm{NbH}$, or other complex hydrides. Several studies have focused on various alloys such as $\mathrm{LaNi}_{5}$ [154], FeTi [155,156], Ti-V-Cr alloys [157-160], and Zr based alloys [161-171]. Vijay et al. [155] studied the effect of FeTi and FeTiMn alloys in different proportions (5-40 $\mathrm{wt} \%)$. The lowest absorption and desorption temperature was found as 80 and $240{ }^{\circ} \mathrm{C}$ respectively for $\mathrm{Mg}-40 \mathrm{wt} \%$ FeTiMn composite. A remarkable decrease in activation energy down to $71 \mathrm{~kJ} / \mathrm{mol} \mathrm{H}_{2}$ was achieved using Ti-Cr-Mn-V BCC alloy [157]. A recent study on several V-based hydride forming materials suggested that better kinetic activity can be achieved with the less stable V-based hydrides [159]. A number of Ti-based alloys have been tried out to enhance the sorption kinetics of $\mathrm{MgH}_{2}$ by Zhou et al. [160]. They suggested that a TiAl compound reduced the desorption activation energy of $\mathrm{MgH}_{2}$ to $65.08 \mathrm{~kJ} / \mathrm{mol} \mathrm{H}$, which makes it one of the best known catalysts in terms of activation energy, whereas, $\mathrm{TiMn}_{2}$ addition improves the hydrogenation kinetics at room temperature with the activation energy of $20.59 \mathrm{~kJ} / \mathrm{mol} \mathrm{H}_{2}$. The addition of $\mathrm{Zr}$ based $\mathrm{AB}_{2}$ type alloys also attracted attention due to their interesting catalytic activity for $\mathrm{MgH}_{2}$ sorption properties. The addition of $\mathrm{ZrCrCu}$ alloy [161] produced $\mathrm{Mg}_{2} \mathrm{Cu}$ phase at the grain boundaries of $\mathrm{Mg}$ and alloy phase during the cycling, which provided diffusion paths and nucleation sites for the easy formation of hydride and enhanced the kinetics. The above reaction was not observed between $\mathrm{Mg}$ and other alloy $\mathrm{ZrCrX}$ (X = Ni, Fe, Mn, Co) composites [163-169].

Sulfide materials having transition metal as cation and $\mathrm{S}$ as anion have attracted attention as catalysts very recently [172-176]. Jia et al. [172] prepared $\mathrm{MgH}_{2}-\mathrm{MoS}_{2}$ composite and suggested the reduced activation energy of $87 \mathrm{~kJ} / \mathrm{mol} \mathrm{H}$ for desorption. This improvement was found to be associated with the in-situ formation of MgS and Mo. Zhang et al. [173,176] studied the effect of iron-based sulfides, i.e., $\mathrm{Fe}_{3} \mathrm{~S}_{4}$ and $\mathrm{FeS}_{2}$, and suggested an almost similar mechanism as found for $\mathrm{MoS}_{2}$ except for the formation of $\mathrm{Mg}_{2} \mathrm{FeH}_{6}$ phase in addition to $\mathrm{MgS}$ and $\mathrm{Fe}$. This reduced the activation energy down to much lower value, i.e., $68.94 \mathrm{~kJ} / \mathrm{mol} \mathrm{H}$, in comparison with $\mathrm{MoS}_{2}$ addition. Even a much lower value of $64.71 \mathrm{~kJ} / \mathrm{mol} \mathrm{H}_{2}$ could be achieved by the addition of flower-like NiS [175]. The mechanism of sorption process for this nanocomposite system is shown in Figure 11. The prepared nanocomposite comprises of $\mathrm{Mg} / \mathrm{NiS}$ core/shell structure. The first sorption cycle decomposes NiS shell into $\mathrm{Ni}, \mathrm{MgS}$, and $\mathrm{Mg}_{2} \mathrm{Ni}$ phases, which are decorated on the surface of $\mathrm{Mg}$ nanoparticles. So this multi component composite ( $\left.\mathrm{Mg}-\mathrm{MgS}-\mathrm{Mg}_{2} \mathrm{Ni}-\mathrm{Ni}\right)$ system shows high sorption rate of hydrogen at lower temperature.

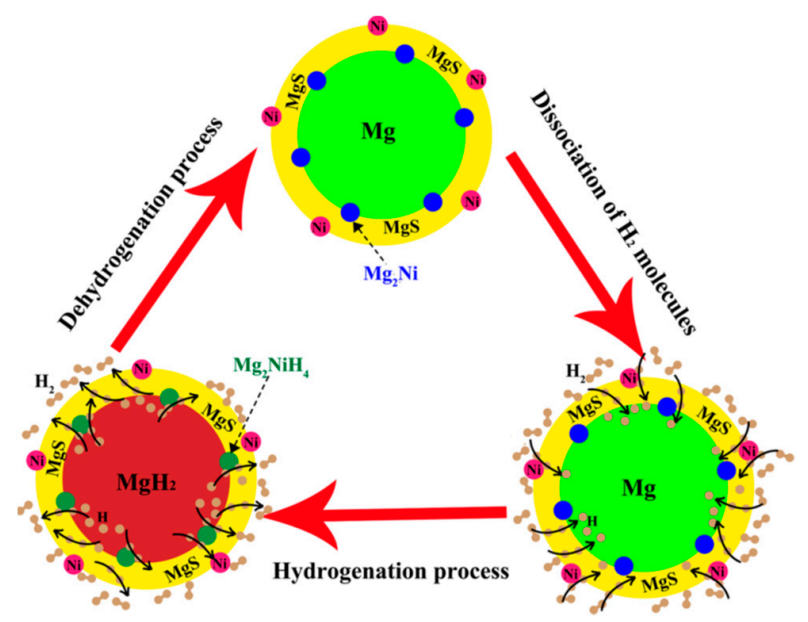

Figure 11. Schematic diagram of the catalytic mechanism of $\mathrm{Ni}, \mathrm{Mg}_{2} \mathrm{Ni}$, and $\mathrm{MgS}$ catalysts during the hydrogenation/dehydrogenation processes of the nanocomposite. Adapted with the permission from [175], copyright ACS, 2017. 


\section{Catalysts for Complex hydrides}

Complex hydrides have attracted attention as hydrogen storage materials during the last two decades [5] owing to their high hydrogen capacity. While complex hydrides have high hydrogen content compared to metal hydrides, i.e., $\mathrm{MgH}_{2}$, they also possess a complex multistep sorption process due to the presence of an $\mathrm{H}$ atom covalently bonded in a tetrahedron $\mathrm{AlH}_{4}$ and $\mathrm{BH}_{4} \mathrm{or} \mathrm{NH}_{2}$ anion, which is bonded with the alkali or alkaline metal cations, thus forming alanate, borohydride, and amide families $[21-24,177,178]$. The presence of strong covalent bonds, i.e., $\mathrm{Al}-\mathrm{H}, \mathrm{B}-\mathrm{H}$, and $\mathrm{N}-\mathrm{H}$, makes them hard to decompose and rehydrogenate. The discovery by Bogdanovic et al. [179] in 1997 of using $\mathrm{TiCl}_{3}$ as catalyst, opened a new era for these complex hydrides by attaining the reversibility of $\mathrm{NaAlH}_{4}$ with sufficiently high kinetics. In this section, we will describe different catalysts for alanate, borohydride, and amides, respectively, in order.

\subsection{Catalysts for Alanates}

The DECOMPOSITION of alanates undergoes through several steps as follows: Alkali metals i.e., $\mathrm{Li}, \mathrm{Na}, \mathrm{K}$

$$
\begin{gathered}
\mathrm{MAlH}_{4} \rightarrow \mathrm{M}_{3} \mathrm{AlH}_{6}+2 \mathrm{Al}+3 \mathrm{H}_{2} \\
\mathrm{M}_{3} \mathrm{AlH}_{6}+2 \mathrm{Al}+3 \mathrm{H}_{2} \rightarrow 3 \mathrm{MH}+3 \mathrm{Al}+9 / 2 \mathrm{H}_{2} \\
3 \mathrm{MH} \rightarrow 3 \mathrm{M}+3 / 2 \mathrm{H}_{2}
\end{gathered}
$$

Magnesium Alanate

$$
\begin{gathered}
\mathrm{Mg}\left(\mathrm{AlH}_{4}\right)_{2} \rightarrow \mathrm{MgH}_{2}+2 \mathrm{Al}+3 \mathrm{H}_{2} \\
\mathrm{MgH}_{2} \rightarrow \mathrm{Mg}+\mathrm{H}_{2}
\end{gathered}
$$

And Calcium Alanate

$$
\begin{aligned}
\mathrm{Ca}\left(\mathrm{AlH}_{4}\right)_{2} & \rightarrow \mathrm{CaAlH}_{5}+\mathrm{Al}+3 / 2 \mathrm{H}_{2} \\
\mathrm{CaAlH}_{5} & \rightarrow \mathrm{CaH}_{2}+\mathrm{Al}+3 / 2 \mathrm{H}_{2}
\end{aligned}
$$

Following the discovery of reversibility in complex hydride by Bogdanovic et al. [179], several methodologies have been adopted such as, nanoscaling, alloying, adding catalysts, etc. However, this review focuses only on the use of catalysts to enhance the kinetics, so will include only this approach and explain the mechanism of catalysis here.

The breakthrough invention of Bogdanovic et al. [179] and the following studies [180-182] suggested that the activation energy for the two steps of $\mathrm{NaAlH}_{4}$ decomposition could be reduced down to 73 and $97 \mathrm{~kJ} / \mathrm{mol} \mathrm{H}$, respectively, by the addition of only $0.9 \mathrm{~mol} \% \mathrm{TiCl}_{3}$ in comparison to 118 and $124 \mathrm{~kJ} / \mathrm{mol} \mathrm{H}_{2}$, respectively, for pure $\mathrm{NaAlH}_{4}$. These preliminary studies have been followed by a number of studies on $\mathrm{TiCl}_{3}$ based catalysts in order to understand the mechanism of catalysis, the effect of preparation method of catalyst etc. [183-186]. The studies were not only limited to $\mathrm{TiCl}_{3}$, several other halides and salts of Ti were also employed to enhance the sorption kinetics of $\mathrm{NaAlH}_{4}$ such as Ti-Al [187,188], $\mathrm{TiB}_{2}$ [189], TiC [190,191], $\mathrm{TiF}_{3}$ [192], TiF 4 [193], TiN [194], Ti-oxides [195,196] etc. The use of $\mathrm{Ti}-\mathrm{Al}$ compounds such as $\mathrm{Ti}_{3} \mathrm{Al}, \mathrm{TiAl}_{3}$ was motivated from the mechanism that the in-situ formed Ti-Al alloys were found responsible for the catalytic enhancement of $\mathrm{TiCl}_{3}$ or $\mathrm{TiCl}_{4}$ added $\mathrm{NaAlH}_{4}$. However, the catalytic performance of Ti-Al is controversial as some researchers have shown that it has no effect on the decomposition of $\mathrm{NaAlH}_{4}$ [187], whereas some groups found significant improvement in desorption of $\mathrm{NaAlH}_{4}$ [188]. Lee et al. [188] prepared Ti-Al powders through different mechanochemical reactions and achieved a good catalytic effect, depending on the particle size of prepared Ti-Al alloys. Not only Ti-halide, but also $\mathrm{TiO}_{2}$ possesses a good catalytic behavior. The addition of nano-crystalline $\mathrm{TiO}_{2}$ supported on nano-porous carbon decreased the desorption temperature of $\mathrm{NaAlH}_{4}$ and enhanced the reaction kinetics. A systematic XPS and TEM study [196] suggested that Ti undergoes a reduction process of $\mathrm{Ti}^{4+}$ to $\mathrm{Ti}^{0}$ during the milling and/or heating process and forms either $\mathrm{TiH}_{2}$ or $\mathrm{Ti}-\mathrm{Al}$ compounds. They also suggested that the catalytic 
effect of Ti based species is in the order of Ti-Al species $>\mathrm{TiH}_{2}>\mathrm{TiO}_{2}$. Inspired by the performance of $\mathrm{TiO}_{2}$, Pukazhselvan et al. [197] studied a number of other metal oxide nano-particles including $\mathrm{TiO}_{2}$, $\mathrm{CeO}_{2}, \mathrm{La}_{2} \mathrm{O}_{3}, \mathrm{Pr}_{2} \mathrm{O}_{3}, \mathrm{Nd}_{2} \mathrm{O}_{3}, \mathrm{Sm}_{2} \mathrm{O}_{3}, \mathrm{Eu}_{2} \mathrm{O}_{3}$, and $\mathrm{Gd}_{2} \mathrm{O}_{3}$, and observed that $\mathrm{TiO}_{2}$ possessed the best catalytic effect among all the studied oxides. It was also pointed out that the catalytic activity was not very good when Ti powder was directly mixed with $\mathrm{NaAlH}_{4}$, even if it has an advantage of being free of inactive byproducts and unwanted gas impurities [198,199]. In another study, Zidan et al. [200] reported that $\mathrm{Zr}$ mixing is inferior to titanium for $\mathrm{NaAlH}_{4}$ to $\mathrm{Na}_{3} \mathrm{AlH}_{6}$ reaction, but superior for $\mathrm{Na}_{3} \mathrm{AlH}_{6}$ to $\mathrm{NaH}$ reaction, thus using a combination of Ti and $\mathrm{Zr}$ mixing together from their precursors $\mathrm{Ti}\left(\mathrm{OBu}^{\mathrm{n}}\right)_{4}$ and $\mathrm{Zr}(\mathrm{OPr})_{4}$, enhanced the overall kinetics of $\mathrm{NaAlH}_{4}$ and showed a stable reversible capacity of more than $4 \mathrm{wt} \%$. Wang et al. [201] reported the synergetic effect of ternary combination of $\mathrm{TiCl}_{3}, \mathrm{ZrCl}_{4}$, and $\mathrm{FeCl}_{3}$ up to a total content of catalyst limit to $4 \mathrm{~mol} \%$ and observed activation energy as low as $76 \mathrm{~kJ} / \mathrm{mol}$ for decomposition of $\mathrm{NaAlH}_{4}$, however, the effect for the second step was not as pronounced as for the first step decomposition. $\mathrm{TiCl}_{3}$ was considered the best catalyst until the discovery of $\mathrm{ScCl}_{3}, \mathrm{CeCl}_{3}$, and $\mathrm{PrCl}_{3}$ by Bogdanovic et al. in 2006 [202,203]. They found that $\mathrm{ScCl}_{3}$ had a nice effect towards improving the storage capacity, whereas $\mathrm{CeCl}_{3}$ and $\mathrm{PrCl}_{3}$ can improve the cyclic stability with a reduced hydrogenation time by a factor of 2 at high pressure and by a factor of 10 at low pressure. Later, Rongeat et al. [204] pointed out that the efficiency of the above dopants is different for absorption and desorption, which suggested that different reaction mechanism and rate limiting steps took place during both steps. Similar to a $\mathrm{TiCl}_{3}$ doped $\mathrm{NaAlH}_{4}$ system, a $\mathrm{CeCl}_{3}$ doped system exhibited the formation of $\mathrm{Ce}-\mathrm{Al}$ species, which are considered as catalytically active for the decomposition of $\mathrm{NaAlH}_{4}$ [205]. Thus, $\mathrm{CeAl}_{2}$ and $\mathrm{CeAl}_{4}$ alloys were directly mixed to $\mathrm{NaAlH}_{4}$ and were found to be quite effective in reducing the activation energy of both steps, which were found in the range of 72-90 and 93-104 kJ/mol $\mathrm{H}_{2}$ for first and second step decomposition [206,207]. Similar to $\mathrm{NaAlH}_{4}$ system, several catalysts were developed for solving the kinetic problem of $\mathrm{LiAlH}_{4}$ decomposition, which included Ti based halides [208-211], other metal halides [212-218], nano-sized oxides [219-221], carbon [222-224], etc. Recently a new class of complex precursors for metal doping are being used, such as $\mathrm{K}_{2} \mathrm{TiF}_{6}$ [225,226], $\mathrm{MnFe}_{2} \mathrm{O}_{4}$ [227,228], $\mathrm{NiFe}_{2} \mathrm{O}_{4}$ [229], $\mathrm{NiCo}_{2} \mathrm{O}_{4}$ [230], $\mathrm{LiTi}_{2} \mathrm{O}_{4}$ [231]. It was suggested that $\mathrm{K}_{2} \mathrm{TiF}_{6}$ reacted with $\mathrm{NaAlH}_{4} / \mathrm{LiAlH}_{4}$ and thus in-situ formed $\mathrm{TiH}_{2}, \mathrm{Al}_{3} \mathrm{Ti}, \mathrm{LiF}$, and $\mathrm{NaH} / \mathrm{KH}$ worked together as an active species for the synergetic catalysis $[225,226]$. The addition of $\mathrm{MnFe}_{2} \mathrm{O}_{4}$ nanoparticles reduced the activation energy of both the steps of $\mathrm{NaAlH}_{4}$ decomposition down to $57 \mathrm{~kJ}$ and $75 \mathrm{~kJ} / \mathrm{mol} \mathrm{H}_{2}$, respectively [227], whereas it was reduced to 67 and $76 \mathrm{~kJ} / \mathrm{mol} \mathrm{H}_{2}$ respectively for both the steps of $\mathrm{LiAlH}_{4}$ decomposition [228]. All of these complex precursors acted as catalyst by following more or less similar mechanism.

In summary, several catalysts have been developed in last two decades, however, the first discovered Ti catalyst is still leading the field in terms of its overall performance. Several efforts have been devoted to understanding the mechanism of Ti induced catalysis in alanates, which were summarized by Terry J. Frankcombe [232]. The earlier mechanism was based on the assumption that the presence of Ti on or in the surface can break and form $\mathrm{H}-\mathrm{H}$ bonds with very low activation energy as compared to other sites, which enhanced the dehydrogenation/hydrogenation kinetics faster [233]. However, this "hydrogen pump" / spillover behavior could not explain the inactive nature of Pd or $\mathrm{Pt}$, which also has the ability of barrier less adsorption of $\mathrm{H}_{2}$ on their surface. Another argument for slow kinetics was given on the basis of nucleation and growth of compact product phases mainly proposed by Fichtner and group [234-236]. Ti particles were suggested to be the centers for nucleation and growth of the decomposed phase $[237,238]$. However, this mechanism also failed to justify the reabsorption process. On the basis of elemental kinetic theory, which suggests the dependence of decomposition temperature of alanates on the $\mathrm{Al}-\mathrm{H}$ bond strength, it was proposed that the Ti catalyst destabilized the Al-H bonds $[239,240]$. Several researchers, on the basis of experimental as well as DFT calculations [241-245], supported the above-mentioned model. Another model based on the existence of Al-H mobile species during decomposition, suggests that the mobility of Al-H species is enhanced due to the hydrogen attached to Ti-Al clusters [246-250]. Araujo et al. [251] proposed a Na vacancy mediated model, according to which Ti catalyst promotes the formation and migration of $\mathrm{Na}$ vacancies 
within alanate crystal. A totally different model based on $\mathrm{AlH}_{3}$ and $\mathrm{NaH}$ mobile species vacancies has been proposed by Gunaydin et al. [251], which was also supported by Borgschulte et al. [252] using the $\mathrm{H}-\mathrm{D}$ exchange experiment. They suggested that $\mathrm{Ti}$ in the alanate system acts as shuttle at the Al-NaAlH 4 interface. Peles and Vande Walle [253] suggested that the charged hydrogen defect formation energy can be decreased through the alteration of Fermi level through Ti doping. This decrease in defect formation energy increases the diffusion rate of these charged defects. This model easily explains the better catalytic activity of Ti as compared to other metals. For example, Zr doping alters the fermi level of alanate by $0.07 \mathrm{eV}$, which is much smaller than $0.44 \mathrm{eV}$ for Ti doping. Thus, the defect formation energy (counts same as the alternation of fermi level) by Ti dopant would be decreased by almost 6 orders more than that for $\mathrm{Zr}$ dopant and enhanced diffusion rate in a much better way. A "zipper model" was recently proposed by Marashdeh et al. [254], where Ti species on the surface of $\mathrm{NaAlH}_{4}$ worked as a slider of a zip, ejecting $\mathrm{Na}$ ions from the subsurface by opening the well-ordered crystal, where they can react quickly. However, this model works only for decomposition reaction like many other models. None of the mechanisms could explain the catalytic effect of Ti for both decomposition and reabsorption. Recently, Atakali et al. [255] proposed a bidirectional mechanism based on the thermodynamic data of all possible hydrides involved in the reaction, which is valid for absorption and desorption. According to this atomistic model, the catalyst transfer of $\mathrm{M}^{+}$ and $\mathrm{H}^{-}$occurs from $\mathrm{AlH}_{4}{ }^{-}$to the $\mathrm{AlH}_{6}{ }^{3-}$, thus acting as a bridge for first step. Again in the second step, Ti acts as bridge to form isolated $\mathrm{MH}$ and leaves $\mathrm{AlH}_{3}$ behind, which decomposes to $\mathrm{Al}$ and $\mathrm{H}_{2}$ spontaneously, as shown in Figure 12.

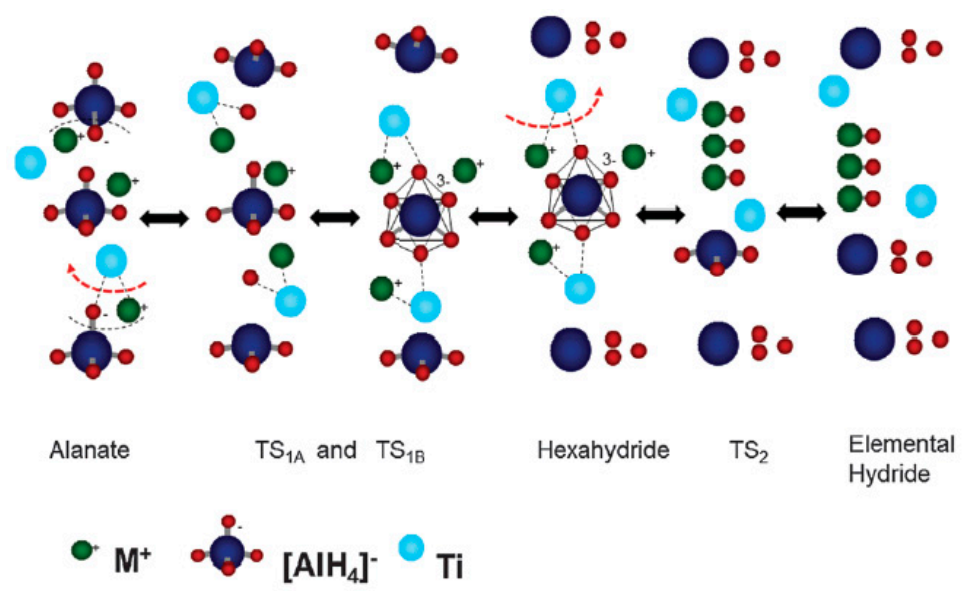

Figure 12. The function of $\mathrm{Ti}$ is to bridge $\mathrm{H}^{-}$and $\mathrm{M}^{+}\left(\mathrm{M}^{+} \ldots \mathrm{Ti} \cdots \mathrm{H}^{-}\right)$in order to remove the ion couple from $\mathrm{MAlH}_{4}$ or $\mathrm{M}_{3} \mathrm{AlH}_{6}$ without the need to transfer individual $\mathrm{M}^{+}$and $\mathrm{H}^{-}$ions. Adapted with the permission from [255], copyright RSC, 2015.

\subsection{Catalysts for Borohydrides}

Borohydrides are considered as favorable materials for hydrogen storage with a high capacity ranging from $10 \sim 18 \mathrm{wt} \%$. All the borohydrides generally decompose through following thermolysis reactions:

$$
\begin{gathered}
\mathrm{MBH}_{4} \rightarrow \mathrm{MH}+\mathrm{B}+3 / 2 \mathrm{H}_{2} \\
\mathrm{MH} \rightarrow \mathrm{M}+1 / 2 \mathrm{H}_{2}
\end{gathered}
$$

Some intermediate products were also reported for some of the borohydrides e.g., formation of $\mathrm{Li}_{2} \mathrm{~B}_{12} \mathrm{H}_{12}$ during decomposition of $\mathrm{LiBH}_{4}$ [256]. The emission of diborane in addition to $\mathrm{H}_{2}$ was also reported [257] for some of the borohydrides. It was found that the charge transfer from $\mathrm{M}^{\mathrm{n}+}$ to $\left[\mathrm{BH}_{4}\right]^{-}$ is a key feature for the stability of $\mathrm{M}\left(\mathrm{BH}_{4}\right)_{\mathrm{n}}$ and is directly related to the Pauling electronegativity $\chi_{\mathrm{p}}$ as shown in Figure 13. The charge transfer becomes smaller with the increasing value of $\chi_{p}$, which makes ionic bonds weaker, thus reducing the decomposition temperature. It was also noticed that the 
borohydride contains $M$ with $\chi_{p} \geq 1.5$ desorb diborane in addition to $\mathrm{H}_{2}$, thus making borohydrides with cation of $\chi_{\mathrm{p}} \leq 1.5$ suitable as hydrogen storage material. It is clear from Figure 13 that the highly stable borohydride has high temperature of hydrogen desorption, so the catalysis has been considered widely and several catalysts have been investigated to reduce the activation barrier and enhance the kinetics of hydrogen release and uptake.

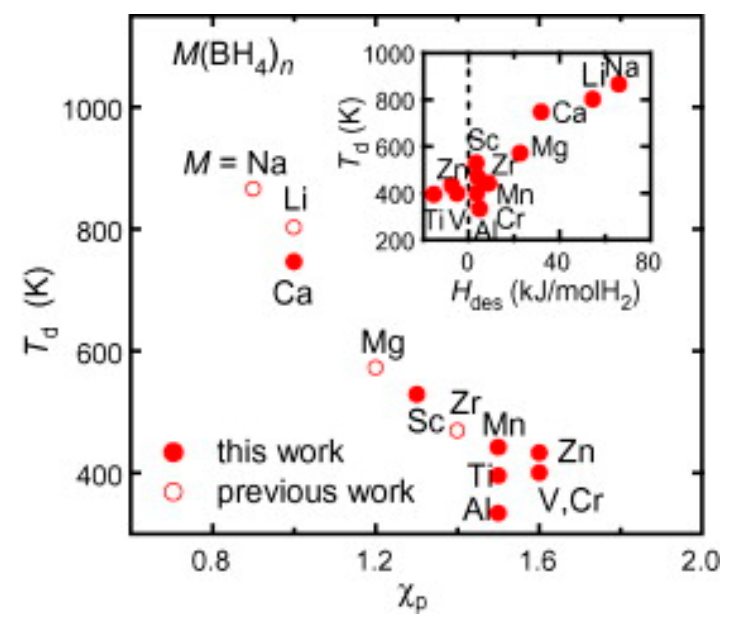

Figure 13. The desorption temperature $T_{d}$ as a function of the Pauling electronegativity $x_{p}$. Adapted with the permission from [257], copyright Elsevier, 2012.

Carbon materials were found to be very effective as an additive. It was suggested that increased curvature of carbon structure reduces the hydrogen removal energy [258]. Various forms of carbon have been employed to improve the kinetics and lower the desorption temperature [259-265]. Yu et al. [259] prepared a mixture of $\mathrm{LiBH}_{4}$ and carbon nanotube mixture by ball milling and showed a lower onset temperature, i.e., $250{ }^{\circ} \mathrm{C}$, of hydrogen desorption. They suggested that the in-situ formed $\mathrm{Li}_{2} \mathrm{C}_{2} \mathrm{can}$ be reversed to $\mathrm{LiH}$, which contributed to almost $1 / 4$ th of total capacity. Carbon nanotubes were also found useful for the kinetic enhancement of $\mathrm{Mg}\left(\mathrm{BH}_{4}\right)_{2}$ recently [260], where the onset temperature of hydrogen desorption was decreased to $120{ }^{\circ} \mathrm{C}$ with an addition of only $5 \mathrm{wt} \%$ of CNT with an activation energy of $130 \mathrm{~kJ} / \mathrm{mol} \mathrm{H}_{2}$, much lower than the pure $\mathrm{Mg}\left(\mathrm{BH}_{4}\right)_{2}$. Fang et al. [261] compared the performance of various carbon additives and concluded that single walled carbon nanotubes (SWNT) and activated carbon (AC) exhibited much better performance than the normal graphite. The use of fluorinated graphene/graphite [263,264] was also found to be quite effective in reducing the dehydrogenation temperature of $\mathrm{LiBH}_{4}$, which alters the thermodynamics as well as kinetics of $\mathrm{LiBH}_{4}$ decomposition. It was suggested that $\mathrm{F}^{-}$substitutes $\mathrm{H}$ anion in $\mathrm{LiBH}_{4}$ or $\mathrm{LiH}_{\text {partially, which }}$ produces the thermodynamic modification. The activation energy was also found to be reduced down to $131 \mathrm{~kJ} / \mathrm{mol} \mathrm{H}_{2}$ from $182 \mathrm{~kJ} / \mathrm{mol} \mathrm{H}_{2}$ for pure $\mathrm{LiBH}_{4}$. Another approach to reduce the activation energy of borohydrides is their nanocaging into carbon scaffold [265]. The onset desorption temperature for nano-caged $\mathrm{LiBH}_{4}$ was found $180{ }^{\circ} \mathrm{C}$ lower than that of pure $\mathrm{LiBH}_{4}$ with a reduced activation energy of $113 \mathrm{~kJ} / \mathrm{mol} \mathrm{H}_{2}$. The in-situ formed $\mathrm{Li}_{3} \mathrm{BO}_{3}$ works as an efficient catalyst for the reversible hydrogenation properties.

Not only the carbon materials, but also carbon/graphene supported metal nanoparticles were used as catalysts for the improvement of sorption properties of borohydrides [266-268]. The use of nano-Ni particles effectively reduced the activation energy of $\mathrm{LiBH}_{4}$ and $\mathrm{Mg}\left(\mathrm{BH}_{4}\right)_{2}$. The values were found as $88 \mathrm{~kJ} / \mathrm{mol} \mathrm{H}_{2}$ [267] and $21.3 \mathrm{~kJ} / \mathrm{mol} \mathrm{H}_{2}$, respectively, which were almost half of bare borohydrides. Xia et al. [269] showed that addition of Ni powder does not alter the thermodynamics but enhances the sorption rate and could be helpful to achieve the partial reversibility at $600{ }^{\circ} \mathrm{C}$ and $10 \mathrm{MPa}_{2}$ pressure. Several other pure metals and non-metals were also examined as catalysts in order to reduce the activation barrier and desorption temperature e.g., $\mathrm{Mg}, \mathrm{Al}, \mathrm{Ti}, \mathrm{Sc}, \mathrm{V}, \mathrm{Cr}, \mathrm{B}$ etc [270-272]. However, it was observed that the use of high amounts of these metals can alter the whole reaction 
pathway instead of reducing the kinetic barrier only. The use of oxide materials as additives to alter the sorption temperature of borohydrides came up in a very early report by Zuttel et al. [273], where $\mathrm{SiO}_{2}$ was mixed with $\mathrm{LiBH}_{4}$ and allowed the release of $\mathrm{H}_{2}$ starting at $250{ }^{\circ} \mathrm{C}$ through the reaction $\mathrm{LiBH}_{4} \rightarrow \mathrm{LiH}+\mathrm{B}+\mathrm{H}_{2}$. Several other oxides namely $\mathrm{ZrO}_{2}, \mathrm{~V}_{2} \mathrm{O}_{3}, \mathrm{SnO}_{2}, \mathrm{TiO}_{2}, \mathrm{Fe}_{2} \mathrm{O}_{3}, \mathrm{~V}_{2} \mathrm{O}_{5}, \mathrm{Nb}_{2} \mathrm{O}_{5}$, $\mathrm{Co}_{3} \mathrm{O}_{4}, \mathrm{MoO}_{3}$, and $\mathrm{ZnO}$ then followed as the target of studies [274-283]. Some of them were claimed to reduce the activation energy of desorption reaction, however, most of them reacted with $\mathrm{LiBH}_{4}$ through redox reactions and thus modified the entire reaction pathway. The next known category of catalyst is halides, which mainly include chloride and fluorides, which were also successfully employed to enhance sorption kinetics of magnesium hydride as well as alanates. With the hope of having similar benefits, several halides were employed as additive with borohydrides [284-303]. It was suggested [284] that transition metal halides reduce the decomposition temperature of $\mathrm{LiBH}_{4}$, however, at the same time the formation of unstable transition metal borohydrides lead to the release of diborane gas due to immediate decomposition, which causes the loss of reversibility. Thus, retaining boron was suggested as a key factor for the reversibility of borohydrides. The addition of $\mathrm{TiF}_{3}$ and $\mathrm{ScCl}_{3}$ to $\mathrm{Mg}\left(\mathrm{BH}_{4}\right)_{2}$ in a small amount of $5 \mathrm{~mol} \%$ could significantly improve the desorption rate [286]. It was suggested that the presence of these additives promote the formation of $\mathrm{MgB}_{12} \mathrm{H}_{12}$ intermediate during rehydrogenation. Similarly $\mathrm{TiF}_{3}$ was also found to be a promising catalyst for $\mathrm{NaBH}_{4}$ decomposition and rehydrogenation process [288]. The dehydrogenation process was suggested to occur in two steps: (i) $\mathrm{NaBH}_{4}$ partially reacted with $\mathrm{TiF}_{3}$ and forms $\mathrm{NaF}, \mathrm{TiB}_{2}$, and $\mathrm{B}$, then (ii) these $\mathrm{Ti}$ and $\mathrm{F}$ species catalyzed the remaining $\mathrm{NaBH}_{4}$. A partial reversibility could be achieved through the formation of intermediate amorphous $\mathrm{Na}_{2} \mathrm{~B}_{12} \mathrm{H}_{12}$ phase as confirmed by fourier transform infra red (FTIR) spectroscopy. Rare earth fluorides have also shown impressive effects on the reversibility of borohydrides through the formation of metal borides such as $\mathrm{PrB}_{4}, \mathrm{NdB}_{6}$ etc. [293-295]. Recently $\mathrm{ZrCl}_{4}$ has shown promising effects on the decomposition of $\mathrm{NaBH}_{4}$ and $\mathrm{Mg}\left(\mathrm{BH}_{4}\right)_{2}[300,301]$. The activation energy could be lowered down to $180 \mathrm{~kJ} / \mathrm{mol} \mathrm{H}_{2}$ from $275 \mathrm{~kJ} / \mathrm{mol} \mathrm{H}_{2}$ through the addition of $\mathrm{ZrCl}_{4}$ to $\mathrm{NaBH}_{4}$. It was suggested that $\mathrm{ZrCl}_{4}$ reduced to $\mathrm{ZrCl}_{2}$ and/or metallic $\mathrm{Zr}$, which acted as catalyst and lowered the dehydrogenation temperature.

In summary, it can be easily seen that the additives can modify the decomposition temperature of borohydrides, however, it is difficult to distinguish the difference between thermodynamic alteration and kinetic modification. Until now, only partial reversibility could be achieved for all the borohydride systems. The key point for the reversibility of borohydride has been decided as "boron retention" during the decomposition rather than the diborane release.

\subsection{Catalysts for Amides}

The discovery of hydrogen absorption by nitride material in 2002 opened up a new class of hydrogen storage materials, named as amide-imide system [304]. The reaction proceeds through the following two reactions:

$$
\begin{aligned}
\mathrm{Li}_{3} \mathrm{~N}+\mathrm{H}_{2} & \leftrightarrow \mathrm{Li}_{2} \mathrm{NH}+\mathrm{LiH} \\
\mathrm{Li}_{2} \mathrm{NH}+\mathrm{H}_{2} & \leftrightarrow \mathrm{LiNH}_{2}+\mathrm{LiH}
\end{aligned}
$$

While the reaction (12) proceeds at high temperature because of high enthalpy value $(-165 \mathrm{~kJ} / \mathrm{mol}$ $\mathrm{H}_{2}$ ), the reaction (13) has a smaller enthalpy of $-44 \mathrm{~kJ} / \mathrm{mol} \mathrm{H}_{2}$ and thus, easily occurs at lower temperatures. So the $\mathrm{LiNH}_{2}+\mathrm{LiH}$ system became one of the most studied systems in the last two decades. It was reported that the desorption reaction of $\mathrm{LiNH}_{2}+\mathrm{LiH}$ is quite slow even at temperatures higher than $200{ }^{\circ} \mathrm{C}$, thus leading to a search for a catalyst to enhance the sorption rate. $\mathrm{TiCl}_{3}$ was the first catalyst, tested with $\mathrm{LiNH}_{2}+\mathrm{LiH}$ system [305-307]. It was observed that the activation energy for pristine $\mathrm{LiNH}_{2}-\mathrm{LiH}$ system was smaller $\left(54 \mathrm{~kJ} / \mathrm{mol} \mathrm{H} \mathrm{H}_{2}\right)$ than the $\mathrm{TiCl}_{3}$ doped $\mathrm{LiNH}_{2}-\mathrm{LiH}$ system $\left(110 \mathrm{~kJ} / \mathrm{mol} \mathrm{H}_{2}\right)$, however the sorption rate of the $\mathrm{TiCl}_{3}$ doped $\mathrm{LiNH}_{2}-\mathrm{LiH}$ system was found to be much better. Thus it was concluded that the catalyzed and non-catalyzed systems undergo different rate limiting steps. The positive effect of $\mathrm{TiCl}_{3}$ addition on the sorption kinetics accelerated several 
studies using different halides for the improvement of the $\mathrm{LiNH}_{2}-\mathrm{LiH}$ system [308-313]. Although the addition of $\mathrm{AlCl}_{3}$ was found effective in enhancing the sorption rate and lowering desorption temperature [308], it was found to occur due to the thermodynamic alteration by the formation of the $\mathrm{Li}-\mathrm{Al}-\mathrm{N}-\mathrm{H}$ system. No actual kinetic alteration could be observed in the $\mathrm{AlCl}_{3}$ modified system. A similar effect was observed for $\mathrm{MgCl}_{2}$ addition, where the formation of the $\mathrm{Li}-\mathrm{Mg}-\mathrm{N}-\mathrm{H}$ system drastically improved the properties of the $\mathrm{Li}-\mathrm{N}-\mathrm{H}$ system [311]. Recently, the sorption kinetics of the $\mathrm{LiNH}_{2}-\mathrm{LiH}$ system could be enhanced by the addition of $\mathrm{Ce}$ based additives, i.e., $\mathrm{CeO}_{2}, \mathrm{CeF}_{3}$, $\mathrm{CeF}_{4}$ [313]. Especially, $\mathrm{CeF}_{4}$ addition showed a significant catalytic effect in reducing the desorption temperature and $\mathrm{NH}_{3}$ suppression by forming $\mathrm{CeF}_{\mathrm{x}}$ species in-situ. The addition of $\mathrm{BN}$ and TiN was also found effective in improving the sorption properties of the $\mathrm{Li}-\mathrm{N}-\mathrm{H}$ system, however they possess different catalytic roles [314]. It was suggested that the catalytic activity originated from the improvement of surface reactivity and diffusion enhancement for TiN and BN respectively. This work also suggested a similar possibility for $\mathrm{TiCl}_{3}$, which can in-situ transform to $\mathrm{TiN}$ and follow the same reactivity for the $\mathrm{Li}-\mathrm{N}-\mathrm{H}$ system.

Apart from the $\mathrm{LiNH}-\mathrm{LiH}$ system, the $\mathrm{LiNH}_{2} / \mathrm{MgH}_{2}$ or $\mathrm{Mg}\left(\mathrm{NH}_{2}\right)_{2} / \mathrm{LiH}$ system has shown much better properties with much lower enthalpy of $34 \mathrm{~kJ} / \mathrm{mol} \mathrm{H}_{2}$ with reasonably high hydrogen capacity of $4.5 \mathrm{wt} \%$ through following reaction:

$$
2 \mathrm{LiNH}_{2}+\mathrm{MgH}_{2} \leftrightarrow \mathrm{Li}_{2} \mathrm{Mg}(\mathrm{NH})_{2}+2 \mathrm{H}_{2}
$$

Several other composition ratios of $\mathrm{Mg}\left(\mathrm{NH}_{2}\right)_{2}$ and $\mathrm{LiH}$, i.e., $3: 8$ or 3:12, were also attempted and a higher capacity was observed for these but the desorption temperature also increased at the same time [315-317]. The lower enthalpy value of this system suggests near ambient temperature desorption, however, it can occur only at more than $150{ }^{\circ} \mathrm{C}$ practically, which must be caused by the kinetic constraints. Thus, in order to improve the sorption kinetics, several additives were attempted with this system [318-326]. Shahi et al. [319] studied the effect of various V-based additives and found $\mathrm{VCl}_{3}$ as the best catalyst among them. The kinetics of $\mathrm{Mg}\left(\mathrm{NH}_{2}\right)_{2} / 2 \mathrm{LiH}$ could be enhanced up to $38 \%$ followed by $20 \%$ and $10 \%$ enhancement for $\mathrm{V}$ and $\mathrm{V}_{2} \mathrm{O}_{5}$ respectively. Hu et al. [321] and Ulmer et al. [322] reported the catalytic effect of $\mathrm{ZrCoH}_{3}$ separately and together with $\mathrm{LiBH}_{4}$. The presence of $\mathrm{LiBH}_{4}$ and $\mathrm{ZrCoH}_{3}$ together showed better catalytic activity, compared to their individual presence. Another high performing catalyst is $\mathrm{RbF}$, the addition of which could significantly enhance the sorption kinetics and reduce the temperature. The $\mathrm{Mg}\left(\mathrm{NH}_{2}\right)_{2}-2 \mathrm{LiH}-0.08 \mathrm{RbF}$ system could store up to $4.76 \mathrm{wt} \%$ hydrogen reversibly with an onset temperature of $80{ }^{\circ} \mathrm{C}$ and $55^{\circ} \mathrm{C}$ for dehydrogenation and rehydrogenation respectively [32]. The addition of carbon has also been found suitable for kinetic enhancement [324,325]. $\mathrm{Ru}$ doped SWNT addition to $\mathrm{Mg}\left(\mathrm{NH}_{2}\right)_{2}-\mathrm{LiH}$ could effectively suppress the $\mathrm{NH}_{3}$ emission as well as enhance the sorption kinetics. Bill et al. [313] studied calcium halides and suggested that both $\mathrm{CaCl}_{2}$ and $\mathrm{CaBr}_{2}$ reduced the onset temperature by 30 and $45^{\circ} \mathrm{C}$ more than the undoped $\mathrm{Li}-\mathrm{Mg}-\mathrm{N}-\mathrm{H}$ system. The activation energies were calculated as 91.8 and $78.8 \mathrm{~kJ} / \mathrm{mol} \mathrm{H}_{2}$ for $\mathrm{CaCl}_{2}$ and $\mathrm{CaBr}_{2}$ doped samples, respectively, in comparison to $104.2 \mathrm{~kJ} / \mathrm{mol} \mathrm{H}_{2}$ for undoped $\mathrm{Li}-\mathrm{Mg}-\mathrm{N}-\mathrm{H}$ system.

Despite several efforts, the dehydrogenation temperature of $\mathrm{Li}-\mathrm{Mg}-\mathrm{N}-\mathrm{H}$ was still higher than the theoretical value of $90^{\circ} \mathrm{C}$ at 1 bar $\mathrm{H}_{2}$ pressure until the discovery of $\mathrm{KH}$ catalyst by Wang et al. in 2009 [326]. The hydrogen desorption peak was shifted to $132{ }^{\circ} \mathrm{C}$ with $\mathrm{KH}$ doping from $186{ }^{\circ} \mathrm{C}$ for undoped $\mathrm{Mg}\left(\mathrm{NH}_{2}\right)_{2} / \mathrm{LiH}$ system as shown in Figure 14 . The addition of only $3 \mathrm{~mol} \% \mathrm{KH}$ could drastically enhance the kinetics of system and allowed the rehydrogenation by the system at 107 ${ }^{\circ} \mathrm{C}$. Following the discovery of above enhancement, several attempts were made to understand the mechanism of this improvement and to optimize other parameters [327-330]. Teng et al. [327] suggested that this improvement can be understood on the basis of $\mathrm{NH}_{3}$ mediated process, where $\mathrm{KH}$ reacts with $\mathrm{NH}_{3}$, emitted from $\mathrm{Mg}\left(\mathrm{NH}_{2}\right)_{2}$, and forms $\mathrm{KNH}_{2}$. This $\mathrm{KNH}_{2}$ immediately reacts with $\mathrm{LiH}$ to regenerate $\mathrm{KH}$. These two processes continue as follows and enhance the decomposition of $\mathrm{Mg}\left(\mathrm{NH}_{2}\right)_{2} / \mathrm{LiH}$ system via the pseudo-catalytic effect of $\mathrm{KH}$ : 


$$
\begin{aligned}
\mathrm{Mg}\left(\mathrm{NH}_{2}\right)_{2} & \leftrightarrow \mathrm{MgNH}+\mathrm{NH}_{3} \\
\mathrm{KH}+\mathrm{NH}_{3} & \leftrightarrow \mathrm{KNH}_{2}+\mathrm{H}_{2} \\
\mathrm{KNH}_{2}+\mathrm{LiH} & \leftrightarrow \mathrm{LiNH}_{2}+\mathrm{KH}
\end{aligned}
$$

The activation energy of this reaction was observed to be reduced down to $87 \mathrm{~kJ} / \mathrm{mol} \mathrm{H}_{2}$ from the $119 \mathrm{~kJ} / \mathrm{mol} \mathrm{H}_{2}$ for undoped system [328]. Luo et al. [329] has shown through the thermodynamic observation by PCT studies that the $\Delta \mathrm{H}$ value remained unchanged for the $\mathrm{K}$-doped and undoped $\mathrm{Mg}\left(\mathrm{NH}_{2}\right)_{2} / \mathrm{LiH}$ system, which suggested the true catalytic nature of $\mathrm{KH}$ instead of thermodynamic alteration. Recently another mechanism has been reported for the abovementioned improvement [330], according to which $\mathrm{KH}$ reacts with $\mathrm{Mg}\left(\mathrm{NH}_{2}\right)_{2}$ and forms stable $\mathrm{K}_{2} \mathrm{Mg}\left(\mathrm{NH}_{2}\right)_{4}$. This kinetically stable $\mathrm{K}_{2} \mathrm{Mg}\left(\mathrm{NH}_{2}\right)_{4}$ phase weakens the $\mathrm{N}-\mathrm{H}$ bonds and reacts with $\mathrm{LiH}$ immediately to produce $\mathrm{KH}$ in a metathesis process. These reactions proceed as follows with enhanced kinetics:

$$
\begin{gathered}
2 \mathrm{KH}+3 \mathrm{Mg}\left(\mathrm{NH}_{2}\right)_{2} \leftrightarrow \mathrm{K}_{2} \mathrm{Mg}\left(\mathrm{NH}_{2}\right)_{4}+2 \mathrm{MgNH}+2 \mathrm{H}_{2} \\
2 \mathrm{~K}_{2} \mathrm{Mg}\left(\mathrm{NH}_{2}\right)_{4}+3 \mathrm{LiH} \leftrightarrow \mathrm{KLi}_{3}\left(\mathrm{NH}_{2}\right)_{4}+2 \mathrm{Mg}\left(\mathrm{NH}_{2}\right)_{4}+3 \mathrm{KH}
\end{gathered}
$$

The above improvement from $\mathrm{KH}$ addition ignited the studies using several other hydrides such as $\mathrm{RbH}, \mathrm{CsH}$, and $\mathrm{CaH}_{2}$ as catalysts [331-335]. Durojaiye et al. [334] showed the catalytic effect in the order of $\mathrm{RbH}>\mathrm{KH}>\mathrm{CsH}>$ uncatalyzed $2 \mathrm{LiNH}_{2} / \mathrm{MgH}_{2}$ system. The higher catalytic role is of $\mathrm{Rb}$, which expands the lattice of $\mathrm{Li}_{2} \mathrm{Mg}(\mathrm{NH})_{2}$ by replacing $\mathrm{Li}$ by $\mathrm{Rb}$ and facilitates the diffusion process. Torre et al. showed the superiority of $\mathrm{CaH}_{2}$ as catalyst, where they found the decomposition started at $78{ }^{\circ} \mathrm{C}$, much lower than $125^{\circ} \mathrm{C}$ for pristine $\mathrm{Mg}\left(\mathrm{NH}_{2}\right)_{2}+2 \mathrm{LiH}$ system [335] with a reduced activation energy of $105 \mathrm{~kJ} / \mathrm{mol} \mathrm{H}$ in comparison to $133.8 \mathrm{~kJ} / \mathrm{mol} \mathrm{H}_{2}$ for the undoped $\mathrm{Mg}\left(\mathrm{NH}_{2}\right)_{2} / \mathrm{LiH}$ system. Inspired by the catalytic effect of $\mathrm{KH}$, Liu et al. [336] studied the effect of potassium halides on the $\mathrm{Mg}\left(\mathrm{NH}_{2}\right)_{2}-2 \mathrm{LiH}$ system and suggested that only $\mathrm{KF}$ addition was beneficial. The KF added sample showed a desorption onset temperature of $80^{\circ} \mathrm{C}$ with a reversible capacity of $5 \mathrm{wt} \%$ via two stage reaction. The reaction of $\mathrm{KF}$ with $\mathrm{LiH}$, converting into $\mathrm{KH}$ and $\mathrm{LiF}$, acts as a catalyst similar to the system with directly $\mathrm{KH}$ added [337,338]. In the recent reports [339,340], the addition of $\mathrm{KOH}$ was found even better than the $\mathrm{KH}$ addition. It was found that $\mathrm{KOH}$ reacts with $\mathrm{Mg}\left(\mathrm{NH}_{2}\right)_{2}$ and $\mathrm{LiH}$ to convert into $\mathrm{Li}_{2} \mathrm{~K}\left(\mathrm{NH}_{2}\right)_{2}, \mathrm{KH}$ and $\mathrm{MgO}$, which enhanced the kinetics and started to decompose at 75 ${ }^{\circ} \mathrm{C}$ with a peak appearing at $120^{\circ} \mathrm{C}$.

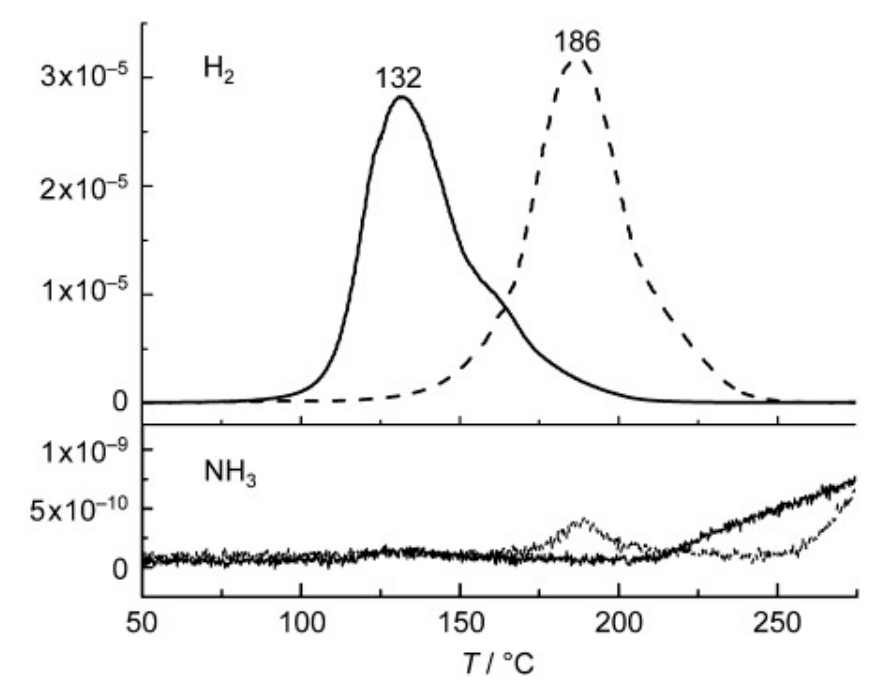

Figure 14. Temperature dependences of $\mathrm{H}_{2}$ and $\mathrm{NH}_{3}$ release from the potassium-modified (-) and the pristine samples (---). Adapted with the permission from [326], copyright Wiley, 2009. 


\subsection{Catalysts for Silanides}

This is the most recent category of hydrogen storage material, which contains the ternary compound of alkali metal, silicon, and hydrogen. This category attracted the attention of hydrogen community with the detailed investigation of hydrogen absorption properties of KSi by a French group in 2011 [341]. The cubic structured KSi with a space group $P 43 n$ transforms to $\mathrm{KSiH}_{3}$ upon hydrogen absorption, which is also crystallized in cubic structure with space group Fm $3 m$. The short $\mathrm{Si}-\mathrm{H}$ bonds $\left(\mathrm{d}_{\mathrm{Si}-\mathrm{H}}=1.47 \AA\right)$, similar to that of silane gas $\left(\mathrm{d}_{\mathrm{Si}-\mathrm{H}}=1.40 \AA\right)$, makes this compound an interesting candidate for hydrogen storage with a very nice $\Delta \mathrm{H}$ value of $-28 \mathrm{~kJ} \mathrm{~mol}^{-1} \mathrm{H}_{2}$. Several other zintl phase alloys with other alkali metals ( $\mathrm{Li}, \mathrm{Na}, \mathrm{Rb}, \mathrm{Cs}$ ) were also investigated for their reversible hydrogenation properties [342-348]. It is very difficult to prepare LiSi single phase by conventional melting method and it needs extremely high temperature $\left(600^{\circ} \mathrm{C}\right)$ and pressure $(4 \mathrm{GPa})$ conditions, however, recently it could be prepared by the ball milling of elemental Li and Si under Ar [343]. Both of the LiSi and NaSi systems undergo disproportionation during the hydrogenation/dehydrogenation reaction, thus losing the reversibility. Thus, the reversibility was observed only in $\mathrm{KSiH}_{3}, \mathrm{RbSiH}_{3}$, and $\mathrm{CsSiH}_{3}$ with a total hydrogen capacity of $4.3,2.6$, and $1.85 \mathrm{wt} \%$ respectively. In spite of having salient features, it is difficult to use $\mathrm{KSiH}_{3}$ or other similar systems for practical applications due to their extremely slow kinetics. The thermodynamics suggest the possibility of room temperature sorption of $\mathrm{KSi} / \mathrm{KSiH}_{3}$ system, however, due to high activation barrier it can absorb hydrogen only at $100{ }^{\circ} \mathrm{C}$ at $5 \mathrm{MPa}_{2}$ pressure and desorb the hydrogen at around $200^{\circ} \mathrm{C}$. Even at such high temperatures, it needs $\sim 5 \mathrm{~h}$ to ab/desorb its total hydrogen content. In the earlier attempts, carbon was added to reduce the activation barrier and enhance the sorption kinetics of $\mathrm{KSi} / \mathrm{KSiH}_{3}$ system [341]. Although it enhances the sorption kinetics, it disproportionates the system into $\mathrm{KH}, \mathrm{Si}$, and $\mathrm{K}-\mathrm{Si}$ intermetallic at the same time, which causes the irreversibility. Later, our group investigated the effect of several known catalysts, i.e., $\mathrm{TiO}_{2}, \mathrm{TiCl}_{3}$, $\mathrm{Nb}_{2} \mathrm{O}_{5}$ [13], and nano metals ( $\mathrm{Ni}, \mathrm{Co}, \mathrm{Nb}$ ) [349]. We achieved drastic improvement by the addition of $5 \mathrm{~mol} \%$ of mesoporous $\mathrm{Nb}_{2} \mathrm{O}_{5}$, which reduced the activation energy from $142 \mathrm{~kJ} \mathrm{~mol}^{-1}$ to $63 \mathrm{~kJ}$ $\mathrm{mol}^{-1}$ [13]. The XPS study suggested that $\mathrm{Nb}_{2} \mathrm{O}_{5}$ was reduced to $\mathrm{NbO}$ phase during milling, which acts as a catalyst for the $\mathrm{H}_{2}$ sorption. In addition, it was also pointed out that the heat management during the exothermic reaction of KSi and hydrogen is an important factor and affected the reversibility of above reaction. It was suggested by Chotard et al. [341] that the excess local heat disproportionates the $\mathrm{KSiH}_{3}$ system, which was avoided by allowing hydrogenation of KSi in controlled way. This was achieved by filling $\mathrm{H}_{2}$ at room temperature followed by the increase of temperature up to the desired value [13]. Using a similar methodology, Janot et al. [350] has shown good performance of $\mathrm{NbF}_{5}$ addition with a low value of activation energy, i.e., $61-66 \mathrm{~kJ} \mathrm{~mol}^{-1}$, in comparison to $121 \mathrm{~kJ}$ $\mathrm{mol}^{-1}$ for the non-catalyzed sample [350].

\section{Concluding Remark \& Future Prospective}

We have reviewed the kinetic modifications of hydrogen storage materials. It is clear that there has been tremendous growth in this field in last few decades. While the heavy metals have quite nice thermodynamics as well as kinetics, these have low gravimetric capacities. On the other hand, the light weight hydrides and complex hydrides can deliver high hydrogen amount, but they suffer from poor thermodynamics as well as sluggish kinetics. While the thermodynamic destabilization can be achieved by alloying and/or inserting an intermediate state, the kinetics can be tuned using several approaches such as nano-sizing, use of catalyst etc. The catalytic modification has several advantages over nano-sizing and several catalysts have been developed so far. In particular, $\mathrm{Nb}_{2} \mathrm{O}_{5}$ has remained the best catalyst for $\mathrm{MgH}_{2}$ over number of years. Also, the newly developed $\mathrm{ZrCl}_{4}$, $\mathrm{TiF}_{4}$, and some complex oxides have shown similar performance to that of $\mathrm{Nb}_{2} \mathrm{O}_{5}$. Ti-based catalysts have shown promising effects for the alanates, whereas no real kinetic alteration could be achieved for borohydrides. The breakthrough discovery of $\mathrm{KH}$ as a catalyst for $\mathrm{Mg}\left(\mathrm{NH}_{2}\right)_{2} / \mathrm{LiH}$ system opened a new family of catalysts for amide systems and several potassium based catalysts have been explored so far. In summary, a lot of developments have been achieved in the field of catalysts for hydrogen 
storage materials with a scope of further enhancement, as the activation barrier still remains as a challenge for several potential candidates. The fundamental mechanism of this catalytic modification is also an important aspect, which still needs to be elaborated in order to establish suitable catalysts. As a concluding remark, we can say that the use of catalysts will be an unavoidable part of hydrogen economy establishment.

Author Contributions: A.J. and T.I. prepared the structure of the manuscript. A.J. and Shivani Agarwal collected all the references and contributed to the writing. T.I. contributed to the revision of the review.

Funding: This research received no external funding.

Acknowledgments: Authors are thankful to Bulbul Jha for the English check of this manuscript.

Conflicts of Interest: The authors declare no conflict of interest.

\section{References}

1. Available online: https://webbook.nist.gov/chemistry/ (accessed on 12 October 2018).

2. Schlapbach, L.; Züttel, A. Hydrogen-storage materials for mobile applications. Nature 2001, 414, 353-358. [CrossRef] [PubMed]

3. Sakintuna, B.; Lamari-Darkrim, F.; Hirscher, M. Metal hydride materials for solid hydrogen storage: A review. Int. J. Hydrogen Energy 2007, 32, 1121-1140. [CrossRef]

4. Lototskyy, M.V.; Tolj, I.; Pickering, L.; Sita, C.; Barbir, F.; Yartys, V. The use of metal hydrides in fuel cell applications. Prog. Nat. Sci. Mater. Int. 2017, 27, 3-20. [CrossRef]

5. Sreedhar, I.; Kamani, K.M.; Kamani, B.M.; Reddy, B.M.; Venugopal, A. A Bird's Eye view on process and engineering aspects of hydrogen storage. Renew. Sustain. Energy Rev. 2018, 91, 838-860. [CrossRef]

6. Rusman, N.A.A.; Dahari, M. A review on the current progress of metal hydrides material for solid-state hydrogen storage applications. Int. J. Hydrogen Energy 2016, 41, 12108-12126. [CrossRef]

7. Available online: https://www.energy.gov/eere/fuelcells/doe-technical-targets-onboard-hydrogenstorage-light-duty-vehicles (accessed on 12 October 2018).

8. Suh, M.P.; Park, H.J.; Prasad, T.K.; Lim, D.-W. Hydrogen Storage in Metal-Organic Frameworks. Chem. Rev. 2012, 112, 782-835. [CrossRef]

9. Yang, J.; Sudik, A.; Wolverton, C.; Siegel, D.J. High capacity hydrogen storage materials: Attributes for automotive applications and techniques for materials discovery. Chem. Soc. Rev. 2010, 39, 656-675. [CrossRef]

10. Jain, I.P.; Lal, C.; Jain, A. Hydrogen storage in Mg: A most promising material. Int. J. Hydrogen Energy 2010, 35, 5133-5144. [CrossRef]

11. Jain, A.; Kawasako, E.; Miyaoka, H.; Ma, T.; Isobe, S.; Ichikawa, T.; Kojima, Y. Destabilization of LiH by Li Insertion into Ge. J. Phys. Chem. C 2013, 117, 5650-5657. [CrossRef]

12. Jain, I.P.; Jain, P.; Jain, A. Novel hydrogen storage materials: A review of lightweight complex hydrides. J. Alloy. Compd. 2010, 503, 303-339. [CrossRef]

13. Jain, A.; Ichikawa, T.; Yamaguchi, S.; Miyaoka, H.; Kojima, Y. Catalytic modification in dehydrogenation properties of $\mathrm{KSiH}_{3}$. Phys. Chem. Chem. Phys. 2014, 16, 26163-26167. [CrossRef] [PubMed]

14. Klerke, A.; Christensen, C.H.; Norskov, J.K.; Vegge, T. Ammonia for hydrogen storage: Challenges and opportunities. J. Mater. Chem. 2008, 18, 2304-2310. [CrossRef]

15. Hu, M.G.; Geanangel, R.A.; Wendlandt, W.W. The thermal decomposition of ammonia borane. Thermochim. Acta 1978, 23, 249-255. [CrossRef]

16. Alhumaidan, F.; Cresswell, D.; Garforth, A. Hydrogen Storage in Liquid Organic Hydride: Producing Hydrogen Catalytically from Methylcyclohexane. Energy Fuels 2011, 25, 4217-4234. [CrossRef]

17. Selvaraj, S.; Jain, A.; Kumar, S.; Zhang, T.; Isobe, S.; Miyaoka, H.; Kojima, Y.; Ichikawa, T. Study of cyclic performance of V-Ti-Cr alloys employed for hydrogen compressor. Int. J. Hydrogen Energy 2018, 43, 2881-2889. [CrossRef]

18. Jain, A.; Miyaoka, H.; Ichikawa, T. Destabilization of lithium hydride by the substitution of group 14 elements: A review. Int. J. Hydrogen Energy 2016, 41, 5969-5978. [CrossRef]

19. Pick, M.A. The kinetics of hydrogen absorption-desorption by Metals. In Metal Hydrides; Bambakidis, G., Ed.; NATO Advanced Study Institute Series; Springer: Boston, MA, USA, 1981; Volume 76. 
20. Martin, M.; Gommel, C.; Borkhart, C.; Fromm, E. Absorption and desorption kinetics of hydrogen storage alloys. J. Alloy. Compd. 1996, 238, 193-201. [CrossRef]

21. Wang, H.; Lin, H.J.; Cai, W.T.; Ouyang, L.Z.; Zhu, M. Tuning kinetics and thermodynamics of hydrogen storage in light metal element based systems-A review of recent progress. J. Alloy. Compd. 2016, 658, 280-300. [CrossRef]

22. Li, J.; Li, B.; Shao, H.; Li, W.; Lin, H. Catalysis and Downsizing in Mg-Based Hydrogen Storage Materials. Catalysts 2018, 8, 89. [CrossRef]

23. Liu, Y.; Yang, Y.; Gao, M.; Pan, H. Tailoring Thermodynamics and Kinetics for Hydrogen Storage in Complex Hydrides towards Applications. Chem. Rec. 2016, 16, 189-204. [CrossRef] [PubMed]

24. Khafidz, N.Z.A.K.; Yaakob, Z.; Lim, K.L.; Timmiati, S.N. The kinetics of lightweight solid-state hydrogen storage materials: A review. Int. J. Hydrogen Energy 2016, 41, 13131-13151. [CrossRef]

25. Bérubé, V.; Radtke, G.; Dresselhaus, M.; Chen, G. Size effects on the hydrogen storage properties of nanostructured metal hydrides: A review. Int. J. Energy Res. 2007, 31, 637-663. [CrossRef]

26. Baldé, C.P.; Hereijgers, B.P.C.; Bitter, J.H.; de Jong, K.P. Sodium Alanate Nanoparticles-Linking Size to Hydrogen Storage Properties. J. Am. Chem. Soc. 2008, 130, 6761-6765. [CrossRef] [PubMed]

27. Aguey-Zinsou, K.-F.; Ares-Fernández, J.-R. Hydrogen in magnesium: New perspectives toward functional stores. Energy Environ. Sci. 2010, 3, 526-543. [CrossRef]

28. Li, W.; Li, C.; Ma, H.; Chen, J. Magnesium Nanowires: Enhanced Kinetics for Hydrogen Absorption and Desorption. J. Am. Chem. Soc. 2007, 129, 6710-6711. [CrossRef] [PubMed]

29. Mushnikov, N.V.; Ermakov, A.E.; Uimin, M.A.; Gaviko, V.S.; Terent'ev, P.B.; Skripov, A.V.; Tankeev, A.P.; Soloninin, A.V.; Buzlukov, A.L. Kinetics of interaction of Mg-based mechanically activated alloys with hydrogen. Phys. Met. Metall. 2006, 102, 421-431. [CrossRef]

30. Stampfer, J.F., Jr.; Holley, C.E., Jr.; Suttle, J.F. The Magnesium-Hydrogen System. J. Am. Chem. Soc. 1960, 82, 3504-3508. [CrossRef]

31. Stander, C.M. Kinetics of decomposition of magnesium hydride. J. Inorg. Nucl. Chem. 1977, 39, $221-223$. [CrossRef]

32. Grant, D. Magnesium Hydride for Hydrogen Storage. In Solid State Hydrogen Storage; Gavin, W., Ed.; Woodhead Publishing: Cambridge, UK, 2008; pp. 357-380.

33. Schlapbach, L.; Shaltiel, D.; Oelhafen, P. Catalytic effect in the hydrogenation of Mg and Mg compounds: Surface analysis of $\mathrm{Mg}-\mathrm{Mg}_{2} \mathrm{Ni}$ and $\mathrm{Mg}_{2} \mathrm{Ni}$. Mater. Res. Bull. 1979, 14, 1235-1246. [CrossRef]

34. Stioui, M.; Grayevski, A.; Resnik, A.; Shaltiel, D.; Kaplan, N. Macroscopic and microscopic kinetics of hydrogen in magnesium-rich compounds. J. Less-Common Met. 1986, 123, 9-24. [CrossRef]

35. Krozer, A.; Kasemo, B. Eqilibrium hydrogen uptake and associated kinetics for the $\mathrm{Mg}-\mathrm{H}_{2}$ system at low pressures. J. Phys. Condens. Matter 1989, 1, 1533-1538. [CrossRef]

36. Luz, Z.; Genossar, J.; Rudman, P.S. Identification of the diffusing atom in $\mathrm{MgH}_{2}$. J. Less-Common Met. 1980, 73, 113-118. [CrossRef]

37. Vigeholm, B.; Kjoller, J.; Larsen, B.; Pedersen, A.S. Formation and decomposition of magnesium hydride. J. Less-Common Met. 1983, 89, 135-144. [CrossRef]

38. Kecik, D.; Aydinol, M.K. Density functional and dynamics study of the dissociative adsorption of hydrogen on Mg (0001) surface. Surf. Sci. 2009, 603, 304-310. [CrossRef]

39. Pozzo, M.; Alfè, D. Hydrogen dissociation and diffusion on transition metal (=Ti, Zr, V, Fe, Ru, Co, Rh, Ni, $\mathrm{Pd}, \mathrm{Cu}, \mathrm{Ag}$ )-doped Mg(0001) surfaces. Int. J. Hydrogen Energy 2009, 34, 1922-1930. [CrossRef]

40. Mamula, B.P.; Novaković, J.G.; Radisavljević, I.; Ivanović, N.; Novaković, N. Electronic structure and charge distribution topology of $\mathrm{MgH}_{2}$ doped with 3d transition metals. Int. J. Hydrogen Energy 2014, 39, 5874-5887. [CrossRef]

41. German, E.; Gebauer, R. Improvement of Hydrogen Vacancy Diffusion Kinetics in $\mathrm{MgH}_{2}$ by Niobium- and Zirconium-Doping for Hydrogen Storage Applications. J. Phys. Chem. C 2016, 120, 4806-4812. [CrossRef]

42. Sun, G.; Li, Y.; Zhao, X.; Mi, Y.; Wang, L. First-Principles Investigation of Energetics and Electronic Structures of $\mathrm{Ni}$ and Sc Co-Doped $\mathrm{MgH}_{2}$. Am. J. Anal. Chem. 2016, 7, 34-42. [CrossRef]

43. Zaluska, A.; Zaluski, L.; Strom-Olsen, J.O. Nanocrystalline magnesium for hydrogen storage. J. Alloy. Compd. 1999, 288, 217-225. [CrossRef] 
44. Liang, G.; Huot, J.; Boily, S.; Neste, A.V.; Schulz, R. Catalytic effect of transition metals on hydrogen sorption in nanocrystalline ball milled $\mathrm{MgH}_{2}-\mathrm{Tm}(\mathrm{Tm}=\mathrm{Ti}, \mathrm{V}, \mathrm{Mn}, \mathrm{Fe}$ and $\mathrm{Ni}$ ) systems. J. Alloy. Compd. 1999, 292, 247-252. [CrossRef]

45. Liang, G.; Huot, J.; Boily, S.; Schulz, R. Hydrogen desorption kinetics of a mechanically milled MgH2 + 5at.\%V nanocomposite. J. Alloy. Compd. 2000, 305, 239-245. [CrossRef]

46. Bobet, J.-L.; Akiba, E.; Darriet, B. Study of Mg-M ( $\mathrm{M}=\mathrm{Co}, \mathrm{Ni}$ and Fe) mixture elaborated by reactive mechanical alloying: Hydrogen sorption properties. Int. J. Hydrogen Energy 2001, 26, 493-501. [CrossRef]

47. Xu, X.; Song, C. Improving hydrogen storage/release properties of magnesium with nano-sized metal catalysts as measured by tapered element oscillating microbalance. Appl. Catal. A Gen. 2006, 300, 130-138. [CrossRef]

48. Hanada, N.; Ichikawa, T.; Fujii, H. Catalytic Effect of Nanoparticle 3d-Transition Metals on Hydrogen Storage Properties in Magnesium Hydride $\mathrm{MgH}_{2}$ Prepared by Mechanical Milling. J. Phys. Chem. B 2005, 109, 7188-7194. [CrossRef] [PubMed]

49. Denis, A.; Sellier, E.; Aymonier, C.; Bobet, J.-L. Hydrogen sorption properties of magnesium particles decorated with metallic nanoparticles as catalyst. J. Alloy. Compd. 2009, 476, 152-159. [CrossRef]

50. Yu, H.; Bennici, S.; Auroux, A. Hydrogen storage and release: Kinetic and thermodynamic studies of $\mathrm{MgH} 2$ activated by transition metal nanoparticles. Int. J. Hydrogen Energy 2014, 39, 11633-11641. [CrossRef]

51. Xie, L.; Liu, Y.; Zhang, X.; Qu, J.; Wang, Y.; Li, X. Catalytic effect of Ni nanoparticles on the desorption kinetics of $\mathrm{MgH}_{2}$ nanoparticles. J. Alloy. Compd. 2009, 482, 388-392. [CrossRef]

52. Zou, J.; Long, S.; Chen, X.; Zeng, X.; Ding, W. Preparation and hydrogen sorption properties of a Ni decorated Mg based Mg@Ni nano-composite. Int. J. Hydrogen Energy 2015, 40, 1820-1828. [CrossRef]

53. Chen, J.; Xia, G.; Guo, Z.; Huang, Z.; Liu, H.; Yu, X. Porous Ni nanofibers with enhanced catalytic effect on the hydrogen storage performance of $\mathrm{MgH}_{2}$. J. Mater. Chem. A 2015, 3, 15843-15848. [CrossRef]

54. El-Eskandarany, M.S.; Shaban, E.; Ali, N.; Aldakheel, F.; Alkandary, A. In-situ catalyzation approach for enhancing the hydrogenation/dehydrogenation kinetics of $\mathrm{MgH}_{2}$ powders with Ni particles. Sci. Rep. 2016, 6, 37335. [CrossRef]

55. Lu, C.; Zou, J.; Zeng, X.; Ding, W. Hydrogen storage properties of core-shell structured Mg@TM (TM = Co, V) composites. Int. J. Hydrogen Energy 2017, 42, 15246-15255. [CrossRef]

56. Imamura, H.; Kusuhara, M.; Minami, S.; Matsumoto, M.; Masanari, K.; Sakata, Y.; Keiji, I.; Toshiharu, F. Carbon nanocomposites synthesized by high-energy mechanical milling of graphite and magnesium for hydrogen storage. Acta Mater. 2003, 51, 6407-6414. [CrossRef]

57. Shang, C.X.; Guo, Z.X. Effect of carbon on hydrogen desorption and absorption of mechanically milled $\mathrm{MgH}_{2}$. J. Power Sources 2004, 129, 73-80. [CrossRef]

58. Wu, C.Z.; Wang, P.; Yao, X.; Liu, C.; Chen, D.M.; Lu, G.Q.; Cheng, H.M. Effect of carbon/noncarbon addition on hydrogen storage behaviors of magnesium hydride. J. Alloy. Compd. 2006, 414, 259-264. [CrossRef]

59. Lillo-Ródenas, M.A.; Guo, Z.X.; Aguey-Zinsou, K.F.; Cazorla-Amorós, D.; Linares-Solano, A. Effects of different carbon materials on $\mathrm{MgH}_{2}$ decomposition. Carbon 2008, 46, 126-137. [CrossRef]

60. Jia, Y.; Guo, Y.; Zou, J.; Yao, X. Hydrogenation/dehydrogenation in $\mathrm{MgH}_{2}$-activated carbon composites prepared by ball milling. Int. J. Hydrogen Energy 2012, 37, 7579-7585. [CrossRef]

61. Popilevsky, L.; Skripnyuk, V.M.; Beregovsky, M.; Sezen, M.; Amouyal, Y.; Rabkin, E. Hydrogen storage and thermal transport properties of pelletized porous $\mathrm{Mg}-2 \mathrm{wt} \%$ multiwall carbon nanotubes and $\mathrm{Mg}-2 \mathrm{wt} . \%$ graphite composites. Int. J. Hydrogen Energy 2016, 41, 14461-14474. [CrossRef]

62. Liu, W.; Setijadi, E.; Crema, L.; Bartali, R.; Laidani, N.; Aguey-Zinsou, K.F.; Speranza, G. Carbon nanostructures/Mg hybrid materials for hydrogen storage. Diam. Relat. Mater. 2018, 82, 19-24. [CrossRef]

63. Fuster, V.; Castro, F.J.; Troiani, H.; Urretavizcaya, G. Characterization of graphite catalytic effect in reactively ball-milled MgH2-C and Mg-C composites. Int. J. Hydrogen Energy 2011, 36, 9051-9061. [CrossRef]

64. Lototskyy, M.; Sibanyoni, J.M.; Denys, R.V.; Williams, M.; Pollet, B.G.; Yartys, V.A. Magnesium-carbon hydrogen storage hybrid materials produced by reactive ball milling in hydrogen. Carbon 2013, 57, $146-160$. [CrossRef]

65. Zaluski, L.; Zaluska, A.; Ström-Olsen, J.O. Nanocrystalline metal hydrides. J. Alloy. Compd. 1997, 253-254, 70-79. [CrossRef]

66. Shang, C.X.; Guo, Z.X. Structural and desorption characterisations of milled $\left(\mathrm{MgH}_{2}+\mathrm{Y}, \mathrm{Ce}\right)$ powder mixtures for hydrogen storage. Int. J. Hydrogen Energy 2007, 32, 2920-2925. [CrossRef] 
67. Zhu, X.; Pei, L.; Zhao, Z.; Liu, B.; Han, S.; Wang, R. The catalysis mechanism of La hydrides on hydrogen storage properties of $\mathrm{MgH}_{2}$ in $\mathrm{MgH}_{2}+$ xwt.\% $\mathrm{LaH}_{3}(\mathrm{x}=0,10,20$, and 30) composites. J. Alloy. Compd. 2013, 577, 64-69. [CrossRef]

68. Song, J.; Zhao, Z.; Zhao, X.; Fu, R.; Han, S. Hydrogen storage properties of $\mathrm{MgH}_{2}$ co-catalyzed by $\mathrm{LaH}_{3}$ and NbH. Int. J. Miner. Metall. Mater. 2017, 24, 1183-1191. [CrossRef]

69. Zou, J.; Zeng, X.; Ying, Y.; Chen, X.; Guo, H.; Zhou, S.; Ding, W. Study on the hydrogen storage properties of core-shell structured $\mathrm{Mg}-\mathrm{RE}(\mathrm{RE}=\mathrm{Nd}, \mathrm{Gd}, \mathrm{Er})$ nano-composites synthesized through arc plasma method. Int. J. Hydrogen Energy 2013, 38, 2337-2346. [CrossRef]

70. Oelerich, W.; Klassen, T.; Bormann, R. Metal oxides as catalysts for improved hydrogen sorption in nanocrystalline Mg-based materials. J. Alloy. Compd. 2001, 315, 237-242. [CrossRef]

71. Song, M.Y.; Bobet, J.-L.; Darriet, B. Improvement in hydrogen sorption properties of Mg by reactive mechanical grinding with $\mathrm{Cr}_{2} \mathrm{O}_{3}, \mathrm{Al}_{2} \mathrm{O}_{3}$ and $\mathrm{CeO}_{2}$. J. Alloy. Compd. 2002, 340, 256-262. [CrossRef]

72. Jung, K.S.; Lee, E.Y.; Lee, K.S. Catalytic effects of metal oxide on hydrogen absorption of magnesium metal hydride. J. Alloy. Compd. 2006, 421, 179-184. [CrossRef]

73. Barkhordarian, G.; Klassen, T.; Bormann, R. Catalytic Mechanism of Transition-Metal Compounds on Mg Hydrogen Sorption Reaction. J. Phys. Chem. B 2006, 110, 11020-11024. [CrossRef]

74. Polanski, M.; Bystrzycki, J. Comparative studies of the influence of different nano-sized metal oxides on the hydrogen sorption properties of magnesium hydride. J. Alloy. Compd. 2009, 486, 697-701. [CrossRef]

75. Barkhordarian, G.; Klassen, T.; Bormann, R. Fast hydrogen sorption kinetics of nanocrystalline Mg using $\mathrm{Nb}_{2} \mathrm{O}_{5}$ as catalyst. Scr. Mater. 2003, 49, 213-217. [CrossRef]

76. Barkhordarian, G.; Klassen, T.; Bormann, R. Effect of $\mathrm{Nb}_{2} \mathrm{O}_{5}$ content on hydrogen reaction kinetics of $\mathrm{Mg}$. J. Alloy. Compd. 2004, 364, 242-246. [CrossRef]

77. Barkhordarian, G.; Klassen, T.; Bormann, R. Kinetic investigation of the effect of milling time on the hydrogen sorption reaction of magnesium catalyzed with different $\mathrm{Nb}_{2} \mathrm{O}_{5}$ contents. J. Alloy. Compd. 2006, 407, $249-255$. [CrossRef]

78. Hanada, N.; Ichikawa, T.; Fujii, H. Catalytic effect of Ni nano-particle and $\mathrm{Nb}$ oxide on H-desorption properties in $\mathrm{MgH}_{2}$ prepared by ball milling. J. Alloy. Compd. 2005, 404-406, 716-719. [CrossRef]

79. Hanada, N.; Ichikawa, T.; Hino, S.; Fujii, H. Remarkable improvement of hydrogen sorption kinetics in magnesium catalyzed with $\mathrm{Nb}_{2} \mathrm{O}_{5}$. J. Alloy. Compd. 2006, 420, 46-49. [CrossRef]

80. Kimura, T.; Miyaoka, H.; Ichikawa, T.; Kojima, Y. Hydrogen absorption of catalyzed magnesium below room temperature. Int. J. Hydrogen Energy 2013, 38, 13728-13733. [CrossRef]

81. Hanada, N.; Ichikawa, T.; Isobe, S.; Nakagawa, T.; Tokoyoda, K.; Honma, T.; Fujii, H.; Kojima, Y. X-ray Absorption Spectroscopic Study on Valence State and Local Atomic Structure of Transition Metal Oxides Doped in $\mathrm{MgH}_{2}$. J. Phys. Chem. C 2009, 113, 13450-13455. [CrossRef]

82. Friedrichs, O.; Aguey-Zinsou, F.K.; Fernández, J.R.A.; Sánchez-López, J.C.; Justo, J.; Klasssen, T.; Bormann, R.; Fernández, A. $\mathrm{MgH}_{2}$ with $\mathrm{Nb}_{2} \mathrm{O}_{5}$ as additive, for hydrogen storage: Chemical, structural and kinetic behavior with heating. Acta Mater. 2006, 54, 105-110. [CrossRef]

83. Friedrichs, O.; Klasssen, T.; Sánchez-López, J.C.; Bormann, R.; Fernández, A. Hydrogen sorption improvement of nanocrystalline $\mathrm{MgH}_{2}$ by $\mathrm{Nb}_{2} \mathrm{O}_{5}$ nanoparticles. Scr. Mater. 2006, 54, 1293-1297. [CrossRef]

84. Aguey-Zinsou, K.-F.; Fernandez, J.R.A.; Klassen, T.; Bormann, R. Effect of $\mathrm{Nb}_{2} \mathrm{O}_{5}$ on $\mathrm{MgH}_{2}$ properties during mechanical milling. Int. J. Hydrogen Energy 2007, 42, 2400-2407. [CrossRef]

85. Conceição, M.O.T.; Brum, M.C.; Santos, D.S.; Dias, M.L. Hydrogen sorption enhancement by $\mathrm{Nb}_{2} \mathrm{O}_{5}$ and $\mathrm{Nb}$ catalysts combined with $\mathrm{MgH}_{2}$. J. Alloy. Compd. 2013, 550, 179-184. [CrossRef]

86. Ma, T.; Isobe, S.; Wang, Y.; Hashimoto, N.; Ohnuki, S. Nb-Gateway for Hydrogen Desorption in $\mathrm{Nb}_{2} \mathrm{O}_{5}$ Catalyzed $\mathrm{MgH}_{2}$ Nanocomposite. J. Phys. Chem. C 2013, 117, 10302-10307. [CrossRef]

87. Pukazhselvan, D.; Antunes, I.; Russo, S.L.; Perez, J.; Fagg, D.P. Synthesis of catalytically active rock salt structured $\mathrm{Mg}_{x} \mathrm{Nb}_{1-x} \mathrm{O}$ nanoparticles for $\mathrm{MgH}_{2}$ system. Int. J. Hydrogen Energy 2014, 39, 18984-18988. [CrossRef]

88. Pukazhselvan, D.; Otero-Irurueta, G.; Pérez, J.; Singh, B.; Fagg, D.P. Crystal structure, phase stoichiometry and chemical environment of $\mathrm{Mg}_{x} \mathrm{Nb}_{y} \mathrm{O}_{x+y}$ nanoparticles and their impact on hydrogen storage in $\mathrm{MgH}_{2}$. Int. J. Hydrogen Energy 2016, 41, 11709-11715. [CrossRef] 
89. Pukazhselvan, D.; Perez, J.; Nasani, N.; Bdikin, I.; Kovalevsky, A.V.; Fagg, D.P. Formation of $\mathrm{Mg}_{\mathrm{x}} \mathrm{Nb}_{\mathrm{y}} \mathrm{O}_{\mathrm{x}+\mathrm{y}}$ through the Mechanochemical Reaction of $\mathrm{MgH}_{2}$ and $\mathrm{Nb}_{2} \mathrm{O}_{5}$, and Its Effect on the Hydrogen-Storage Behavior of $\mathrm{MgH}_{2}$. ChemPhysChem 2016, 17, 178-183. [CrossRef]

90. Oelerich, W.; Klassen, T.; Bormann, R. Comparison of the catalytic effects of $\mathrm{V}, \mathrm{V}_{2} \mathrm{O}_{5}, \mathrm{VN}$, and VC on the hydrogen sorption of nanocrystalline Mg. J. Alloy. Compd. 2001, 322, L5-L9. [CrossRef]

91. Milošević, S.; Rašković-Lovre, Ž.; Kurko, S.; Vujasin, R.; Cvjetićanin, N.; Matović, L.; Novaković, J.G. Influence of $\mathrm{VO}_{2}$ nanostructured ceramics on hydrogen desorption properties from magnesium hydride. Ceram. Int. 2013, 39, 51-56. [CrossRef]

92. Milošević, S.; Kurko, S.; Pasquini, L.; Matović, L.; Vujasin, R.; Novaković, N.; Novaković, J.G. Fast hydrogen sorption from $\mathrm{MgH}_{2}-\mathrm{VO}_{2}$ (B) composite materials. J. Power Sources 2016, 307, 481-488. [CrossRef]

93. Dehouche, Z.; Klassen, T.; Oelerich, W.; Goyette, J.; Bose, T.K.; Schulz, R. Cycling and thermal stability of nanostructured $\mathrm{MgH}_{2}-\mathrm{Cr}_{2} \mathrm{O}_{3}$ composite for hydrogen storage. J. Alloy. Compd. 2002, 347, 319-323. [CrossRef]

94. Vijay, R.; Sundaresan, R.; Maiya, M.P.; Murthy, S.S. Hydrogen storage properties of $\mathrm{Mg}_{-}-\mathrm{Cr}_{2} \mathrm{O}_{3}$ nanocomposites: The role of catalyst distribution and grain size. J. Alloy. Compd. 2006, 424, 289-293. [CrossRef]

95. Polanski, M.; Bystrzycki, J.; Plocinski, T. The effect of milling conditions on microstructure and hydrogen absorption/desorption properties of magnesium hydride $\left(\mathrm{MgH}_{2}\right)$ without and with $\mathrm{Cr}_{2} \mathrm{O}_{3}$ nanoparticles. Int. J. Hydrogen Energy 2008, 33, 1859-1867. [CrossRef]

96. Polanski, M.; Bystrzycki, J.; Varin, R.A.; Plocinski, T.; Pisarek, M. The effect of chromium (III) oxide $\left(\mathrm{Cr}_{2} \mathrm{O}_{3}\right)$ nanopowder on the microstructure and cyclic hydrogen storage behavior of magnesium hydride $\left(\mathrm{MgH}_{2}\right)$. J. Alloy. Compd. 2011, 509, 2386-2391. [CrossRef]

97. Wang, P.; Wang, A.M.; Zhang, H.F.; Ding, B.Z.; Hu, Z.Q. Hydrogenation characteristics of Mg-TiO 2 (rutile) composite. J. Alloy. Compd. 2000, 313, 218-223. [CrossRef]

98. Jung, K.S.; Kim, D.H.; Lee, E.Y.; Lee, K.S. Hydrogen sorption of magnesium hydride doped with nano-sized $\mathrm{TiO}_{2}$. Catal. Today 2007, 120, 270-275. [CrossRef]

99. Jardim, P.M.; Conceição, M.O.T.; Brum, M.C.; dos Santos, D.S. Hydrogen sorption kinetics of ball-milled $\mathrm{MgH}_{2}-\mathrm{TiO}_{2}$ based 1D nanomaterials with different morphologies. Int. J. Hydrogen Energy 2015, 40, 17110-17117. [CrossRef]

100. Chen, B.-H.; Chuang, Y.-S.; Chen, C.-K. Improving the hydrogenation properties of $\mathrm{MgH}_{2}$ at room temperature by doping with nano-size $\mathrm{ZrO}_{2}$ catalyst. J. Alloy. Compd. 2016, 655, 21-27. [CrossRef]

101. Gupta, R.; Agresti, F.; Russo, S.L.; Maddalena, A.; Palade, P.; Principi, G. Structure and hydrogen storage properties of $\mathrm{MgH}_{2}$ catalysed with $\mathrm{La}_{2} \mathrm{O}_{3}$. J. Alloy. Compd. 2008, 450, 310-313. [CrossRef]

102. Singh, R.K.; Sadhasivam, T.; Sheeja, G.I.; Singh, P.; Srivastava, O.N. Effect of different sized $\mathrm{CeO}_{2}$ nano particles on decomposition and hydrogen absorption kinetics of magnesium hydride. Int. J. Hydrogen Energy 2013, 38, 6221-6225. [CrossRef]

103. Lin, H.-J.; Tang, J.-J.; Yu, Q.; Wang, H.; Ouyang, L.-Z.; Zhao, Y.-J.; Liu, J.-W.; Wang, W.-H.; Zhu, M. Symbiotic $\mathrm{CeH}_{2.73} / \mathrm{CeO}_{2}$ catalyst: A novel hydrogen pump. Nano Energy 2014, 9, 80-87. [CrossRef]

104. Mustafa, N.S.; Ismail, M. Hydrogen sorption improvement of $\mathrm{MgH}_{2}$ catalyzed by $\mathrm{CeO}_{2}$ nanopowder. J. Alloy. Compd. 2017, 695, 2532-2538. [CrossRef]

105. Shan, J.; Li, P.; Wan, Q.; Zhai, F.; Zhang, J.; Li, Z.; Liu, Z.; Volinsky, A.A.; Qu, X. Significantly improved dehydrogenation of ball-milled $\mathrm{MgH}_{2}$ doped with $\mathrm{CoFe}_{2} \mathrm{O}_{4}$ nanoparticles. J. Power Sources 2014, 268, 778-786. [CrossRef]

106. Wan, Q.; Li, P.; Shan, J.; Zhai, F.; Li, Z.; Qu, X. Superior Catalytic Effect of Nickel Ferrite Nanoparticles in Improving Hydrogen Storage Properties of $\mathrm{MgH}_{2}$. J. Phys. Chem. C 2015, 119, 2925-2934. [CrossRef]

107. Juahir, N.; Mustafa, N.S.; Sinin, A.M.; Ismail, M. Improved hydrogen storage properties of $\mathrm{MgH}_{2}$ by addition of $\mathrm{Co}_{2} \mathrm{NiO}$ nanoparticles. RSC Adv. 2015, 5, 60983-60989. [CrossRef]

108. Mustafa, N.S.; Sulaiman, N.N.; Ismail, M. Effect of $\mathrm{SrFe}_{12} \mathrm{O}_{19}$ nanopowder on the hydrogen sorption properties of $\mathrm{MgH}_{2}$. RSC Adv. 2016, 6, 110004-110010. [CrossRef]

109. Zhang, T.; Isobe, S.; Jain, A.; Wang, Y.; Yamaguchi, S.; Miyaoka, H.; Ichikawa, T.; Kojima, Y.; Hashimoto, N. Enhancement of hydrogen desorption kinetics in magnesium hydride by doping with lithium metatitanate. J. Alloy. Compd. 2017, 711, 400-405. [CrossRef] 
110. Idris, N.H.; Mustafa, N.S.; Ismail, $\mathrm{M}$. $\mathrm{MnFe}_{2} \mathrm{O}_{4}$ nanopowder synthesised via a simple hydrothermal method for promoting hydrogen sorption from $\mathrm{MgH}_{2}$. Int. J. Hydrogen Energy 2017, 42, 21114-21120. [CrossRef]

111. Zhang, L.; Chen, L.; Fan, X.; Xiao, X.; Zheng, J.; Huang, X. Enhanced hydrogen storage properties of $\mathrm{MgH}_{2}$ with numerous hydrogen diffusion channels provided by $\mathrm{Na}_{2} \mathrm{Ti}_{3} \mathrm{O}_{7}$ nanotubes. J. Mater. Chem. A 2017, 5, 6178-6185. [CrossRef]

112. Xu, G.; Shen, N.; Chen, L.; Chen, Y.; Zhang, W. Effect of $\mathrm{BiVO}_{4}$ additive on the hydrogen storage properties of $\mathrm{MgH}_{2}$. Mater. Res. Bull. 2017, 89, 197-203. [CrossRef]

113. Ares-Fernández, J.-R.; Aguey-Zinsou, K.-F. Superior $\mathrm{MgH}_{2}$ Kinetics with $\mathrm{MgO}$ Addition: A Tribological Effect. Catalysts 2012, 2, 330-343. [CrossRef]

114. Bhat, V.V.; Rougier, A.; Aymard, L.; Darok, X.; Nazri, G.; Tarascon, J.M. Catalytic activity of oxides and halides on hydrogen storage of $\mathrm{MgH}_{2}$. J. Power Sources 2006, 159, 107-110. [CrossRef]

115. Malka, I.E.; Czujko, T.; Bystrzycki, J. Catalytic effect of halide additives ball milled with magnesium hydride. Int. J. Hydrogen Energy 2010, 35, 1706-1712. [CrossRef]

116. Malka, I.E.; Pisarek, M.; Czujko, T.; Bystrzycki, J. A study of the $\mathrm{ZrF}_{4}, \mathrm{NbF}_{5}, \mathrm{TaF}_{5}$, and $\mathrm{TiCl}_{3}$ influences on the $\mathrm{MgH}_{2}$ sorption properties. Int. J. Hydrogen Energy 2011, 36, 12909-12917. [CrossRef]

117. Jin, S.-A.; Shim, J.-H.; Cho, Y.W.; Yi, K.-W. Dehydrogenation and hydrogenation characteristics of $\mathrm{MgH}_{2}$ with transition metal fluorides. J. Power Sources 2007, 172, 859-862. [CrossRef]

118. Yu, Z.; Liu, Y.; Erde, W. Hydrogen storage properties of the $\mathrm{Mg}-\mathrm{Ni}-\mathrm{CrCl}_{3}$ nanocomposite. J. Alloy. Compd. 2002, 333, 207-214.

119. Mao, J.; Guo, Z.; Yu, X.; Liu, H.; Wu, Z.; Ni, J. Enhanced hydrogen sorption properties of Ni and Co-catalyzed $\mathrm{MgH}_{2}$. Int. J. Hydrogen Energy 2010, 35, 4569-4575. [CrossRef]

120. Cui, J.; Wang, H.; Liu, J.; Ouyang, L.; Zhang, Q.; Sun, D.; Yao, X.; Zhu, M. Remarkable enhancement in dehydrogenation of $\mathrm{MgH}_{2}$ by a nano-coating of multi-valence Ti-based catalysts. J. Mater. Chem. A 2013, 1, 5603-5611. [CrossRef]

121. Ismail, $\mathrm{M}$. Influence of different amounts of $\mathrm{FeCl}_{3}$ on decomposition and hydrogen sorption kinetics of $\mathrm{MgH}_{2}$. Int. J. Hydrogen Energy 2014, 39, 2567-2574. [CrossRef]

122. Ismail, M. Effect of $\mathrm{LaCl}_{3}$ addition on the hydrogen storage properties of $\mathrm{MgH}_{2}$. Energy 2015, 79, $177-182$. [CrossRef]

123. Ismail, M.; Mustafa, N.S.; Juahir, N.; Yap, F.A.H. Catalytic effect of $\mathrm{CeCl}_{3}$ on the hydrogen storage properties of $\mathrm{MgH}_{2}$. Mater. Chem. Phys. 2016, 170,77-82. [CrossRef]

124. Kumar, S.; Jain, A.; Yamaguchi, S.; Miyaoka, H.; Ichikawa, T.; Mukherjee, A.; Dey, G.K.; Kojima, Y. Surface modification of $\mathrm{MgH}_{2}$ by $\mathrm{ZrCl}_{4}$ to tailor the reversible hydrogen storage performance. Int. J. Hydrogen Energy 2017, 42, 6152-6159. [CrossRef]

125. Ma, L.-P.; Kang, X.-D.; Dai, H.-B.; Liang, Y.; Fang, Z.-Z.; Wang, P.-J.; Wang, P.; Cheng, H.-M. Superior catalytic effect of $\mathrm{TiF}_{3}$ over $\mathrm{TiCl}_{3}$ in improving the hydrogen sorption kinetics of $\mathrm{MgH}_{2}$ : Catalytic role of fluorine anion. Acta Mater. 2009, 57, 2250-2258. [CrossRef]

126. Ma, L.-P.; Wang, P.; Cheng, H.-M. Hydrogen sorption kinetics of $\mathrm{MgH}_{2}$ catalyzed with titanium compounds. Int. J. Hydrogen Energy 2010, 35, 3046-3050. [CrossRef]

127. Wang, J.; Du, Y.; Sun, L.; Li, X. Effects of $\mathrm{F}$ and $\mathrm{Cl}$ on the stability of $\mathrm{MgH}_{2}$. Int. J. Hydrogen Energy 2014, 39, 877-883. [CrossRef]

128. Jain, P.; Dixit, V.; Jain, A.; Srivastava, O.N.; Huot, J. Effect of Magnesium Fluoride on Hydrogenation Properties of Magnesium Hydride. Energies 2015, 8, 12546-12556. [CrossRef]

129. Lin, H.-J.; Matsuda, J.; Li, H.-W.; Zhu, M.; Akiba, E. Enhanced hydrogen desorption property of $\mathrm{MgH}_{2} \mathrm{with}$ the addition of cerium fluorides. J. Alloy. Compd. 2015, 645, S392-S396. [CrossRef]

130. Recham, N.; Bhat, V.V.; Kandavel, M.; Aymard, L.; Rougier, A. Reduction of hydrogen desorption temperature of ball-milled $\mathrm{MgH}_{2}$ by $\mathrm{NbF}_{5}$ addition. J. Alloy. Compd. 2008, 464, 377-382. [CrossRef]

131. Danaie, M.; Mitlin, D. TEM analysis of the microstructure in $\mathrm{TiF}_{3}$-catalyzed and pure $\mathrm{MgH}_{2}$ during the hydrogen storage cycling. Acta Mater. 2012, 60, 6441-6456. [CrossRef]

132. Jangir, M.; Jain, A.; Yamaguchi, S.; Ichikawa, T.; Lal, C.; Jain, I.P. Catalytic effect of $\mathrm{TiF}_{4}$ in improving hydrogen storage properties of $\mathrm{MgH}_{2}$. Int. J. Hydrogen Energy 2016, 41, 14178-14183. [CrossRef]

133. Jain, A.; Agarwal, S.; Kumar, S.; Yamaguchi, S.; Miyaoka, H.; Kojima, Y.; Ichikawa, T. How does $\mathrm{TiF}_{4}$ affect the decomposition of $\mathrm{MgH}_{2}$ and its complex variants?-An XPS investigation. J. Mater. Chem. A 2017, 5, 15543-15551. [CrossRef] 
134. Mustafa, N.S.; Ismail, M. Influence of $\mathrm{K}_{2} \mathrm{TiF}_{6}$ additive on the hydrogen sorption properties of $\mathrm{MgH}_{2}$. Int. J. Hydrogen Energy 2014, 39, 15563-15569. [CrossRef]

135. Yap, F.A.H.; Mustafa, N.S.; Ismail, M. A study on the effects of $\mathrm{K}_{2} \mathrm{ZrF}_{6}$ as an additive on the microstructure and hydrogen storage properties of $\mathrm{MgH}_{2}$. RSC Adv. 2015, 5, 9255-9260.

136. Sulaiman, N.N.; Juahir, N.; Mustafa, N.S.; Yap, F.A.H.; Ismail, M. Improved hydrogen storage properties of $\mathrm{MgH}_{2}$ catalyzed with $\mathrm{K}_{2} \mathrm{NiF}_{6}$. J. Energy Chem. 2016, 25, 832-839. [CrossRef]

137. Sulaiman, N.N.; Mustafa, N.S.; Ismail, M. Effect of $\mathrm{Na}_{3} \mathrm{FeF}_{6}$ catalyst on the hydrogen storage properties of $\mathrm{MgH}_{2}$. Dalton Trans. 2016, 45, 7085-7093. [CrossRef]

138. Choi, Y.J.; Lu, J.; Sohn, H.Y.; Fang, Z.Z. Hydrogen storage properties of the Mg-Ti-H system prepared by high-energy-high-pressure reactive milling. J. Power Sources 2008, 180, 491-497. [CrossRef]

139. Lu, J.; Choi, Y.J.; Fang, Z.Z.; Sohn, H.Y.; Rönnebro, E. Hydrogen Storage Properties of Nanosized $\mathrm{MgH}_{2}-0.1 \mathrm{TiH}_{2}$ Prepared by Ultrahigh-Energy-High-Pressure Milling. J. Am. Chem. Soc. 2009, 131, 15843-15852. [CrossRef] [PubMed]

140. Lu, J.; Choi, Y.J.; Fang, Z.Z.; Sohn, H.Y.; Rönnebro, E. Hydrogenation of Nanocrystalline Mg at Room Temperature in the Presence of $\mathrm{TiH}_{2}$. J. Am. Chem. Soc. 2010, 132, 6616-6617. [CrossRef]

141. Sabitu, S.T.; Gallo, G.; Goudy, A.J. Effect of $\mathrm{TiH}_{2}$ and $\mathrm{Mg}_{2} \mathrm{Ni}$ additives on the hydrogen storage properties of magnesium hydride. J. Alloy. Compd. 2010, 499, 35-38. [CrossRef]

142. Cuevas, F.; Korablova, D.; Latroche, M. Synthesis, structural and hydrogenation properties of Mg-rich $\mathrm{MgH}_{2}-\mathrm{TiH}_{2}$ nanocomposites prepared by reactive ball milling under hydrogen gas. Phys. Chem. Chem. Phys. 2012, 14, 1200-1211. [CrossRef]

143. Jangir, M.; Jain, A.; Agarwal, S.; Zhang, T.; Kumar, S.; Selvaraj, S.; Ichikawa, T.; Jain, I.P. The enhanced de/re-hydrogenation performance of $\mathrm{MgH}_{2}$ with $\mathrm{TiH}_{2}$ additive. Int. J. Energy Res. 2018, 42, 1139-1147. [CrossRef]

144. Bhatnagar, A.; Johnson, J.K.; Shaz, M.A.; Srivastava, O.N. $\mathrm{TiH}_{2}$ as a Dynamic Additive for Improving the De/Rehydrogenation Properties of $\mathrm{MgH}_{2}$ : A Combined Experimental and Theoretical Mechanistic Investigation. J. Phys. Chem. C 2018, 122, 21248-21261. [CrossRef]

145. Yavari, A.R.; de Castro, J.F.R.; Vaughan, G.; Heunen, G. Structural evolution and metastable phase detection in $\mathrm{MgH}_{2}-5 \% \mathrm{NbH}$ nanocomposite during in-situ H-desorption in a synchrotron beam. J. Alloy. Compd. 2003, 353, 246-251. [CrossRef]

146. Liu, H.; Wang, X.; Liu, Y.; Dong, Z.; Ge, H.; Li, S.; Yan, M. Hydrogen Desorption Properties of the $\mathrm{MgH}_{2}-\mathrm{AlH}_{3}$ Composites. J. Phys. Chem. C 2014, 118, 37-45. [CrossRef]

147. Mustafa, N.S.; Ismail, M. Enhanced hydrogen storage properties of $4 \mathrm{MgH}_{2}+\mathrm{LiAlH}_{4}$ composite system by doping with $\mathrm{Fe}_{2} \mathrm{O}_{3}$ nanopowder. Int. J. Hydrogen Energy 2014, 39, 7834-7841. [CrossRef]

148. Ismail, M.; Zhao, Y.; Yu, X.B.; Mao, J.F.; Dou, S.X. The hydrogen storage properties and reaction mechanism of the $\mathrm{MgH}_{2}-\mathrm{NaAlH}_{4}$ composite system. Int. J. Hydrogen Energy 2011, 36, 9045-9050. [CrossRef]

149. Plerdsranoy, P.; Meethom, S.; Utke, R. Dehydrogenation kinetics, reversibility, and reaction mechanisms of reversible hydrogen storage material based on nanoconfined $\mathrm{MgH}_{2}-\mathrm{NaAlH}_{4}$. J. Phys. Chem. Solids 2015, 87, 16-22. [CrossRef]

150. Johnson, S.R.; Anderson, P.A.; Edwards, P.P.; Gameson, I.; Prendergast, J.W.; Al-Mamouri, M.; Book, D.; Harris, I.R.; Speight, J.D.; Walton, A. Chemical activation of $\mathrm{MgH}_{2}$; a new route to superior hydrogen storage materials. Chem. Commun. 2005, 22, 2823-2825. [CrossRef] [PubMed]

151. Bösenberg, U.; Doppiu, S.; Mosegaard, L.; Barkhordarian, G.; Eigen, N.; Borgschulte, A.; Torben, R.J.; Yngve, C.; Oliver, G.; Thomas, K.; et al. Hydrogen sorption properties of $\mathrm{MgH}_{2}-\mathrm{LiBH}_{4}$ composites. Acta Mater. 2007, 55, 3951-3958. [CrossRef]

152. Pan, Y.; Leng, H.; Wei, J.; Li, Q. Effect of $\mathrm{LiBH}_{4}$ on hydrogen storage property of $\mathrm{MgH}_{2}$. Int. J. Hydrogen Energy 2013, 38, 10461-10469. [CrossRef]

153. Czujko, T.; Varin, R.A.; Wronski, Z.; Zaranski, Z.; Durejko, T. Synthesis and hydrogen desorption properties of nanocomposite magnesium hydride with sodium borohydride $\left(\mathrm{MgH}_{2}+\mathrm{NaBH}_{4}\right)$. J. Alloy. Compd. 2007, 427, 291-299. [CrossRef]

154. Pan, Y.-B.; Wu, Y.-F.; Li, Q. Modeling and analyzing the hydriding kinetics of $\mathrm{Mg}-\mathrm{LaNi}_{5}$ composites by Chou model. Int. J. Hydrogen Energy 2011, 36, 12892-12901. [CrossRef] 
155. Vijay, R.; Sundaresan, R.; Maiya, M.P.; Murthy, S.S.; Fu, Y.; Klein, H.-P.; Groll, M. Characterisation of Mg-x wt.\% FeTi $(x=5-30)$ and Mg-40wt.\% FeTiMn hydrogen absorbing materials prepared by mechanical alloying. J. Alloy. Compd. 2004, 384, 283-295. [CrossRef]

156. Amirkhiz, B.S.; Zahiri, B.; Kalisvaart, P.; Mitlin, D. Synergy of elemental Fe and Ti promoting low temperature hydrogen sorption cycling of magnesium. Int. J. Hydrogen Energy 2011, 36, 6711-6722. [CrossRef]

157. Yu, X.B.; Yang, Z.X.; Liu, H.K.; Grant, D.M.; Walker, G.S. The effect of a Ti-V-based BCC alloy as a catalyst on the hydrogen storage properties of $\mathrm{MgH}_{2}$. Int. J. Hydrogen Energy 2010, 35, 6338-6344. [CrossRef]

158. Laversenne, L.; Andrieux, J.; Plante, D.; Lyard, L.; Miraglia, S. In operando study of TiVCr additive in $\mathrm{MgH}_{2}$ composites. Int. J. Hydrogen Energy 2013, 38, 11937-11945. [CrossRef]

159. Ren, C.; Fang, Z.Z.; Zhou, C.; Lu, J.; Ren, Y.; Zhang, X. Hydrogen Storage Properties of Magnesium Hydride with V-Based Additives. J. Phys. Chem. C 2014, 118, 21778-21784. [CrossRef]

160. Zhou, C.; Fang, Z.Z.; Ren, C.; Li, J.; Lu, J. Effect of Ti Intermetallic Catalysts on Hydrogen Storage Properties of Magnesium Hydride. J. Phys. Chem. C 2013, 117, 12973-12980. [CrossRef]

161. Agarwal, S.; Jain, A.; Jain, P.; Jangir, M.; Jain, I.P. Kinetic Enhancement in the Sorption Properties by Forming Mg-x wt \% ZrCrCu Composites. J. Phys. Chem. C 2013, 117, 11953-11959. [CrossRef]

162. Kim, J.-H.; Kim, J.-H.; Hwang, K.-T.; Kang, Y.-M. Hydrogen storage in magnesium based-composite hydride through hydriding combustion synthesis. Int. J. Hydrogen Energy 2010, 35, 9641-9645. [CrossRef]

163. Agarwal, S.; Aurora, A.; Jain, A.; Jain, I.P.; Montone, A. Catalytic effect of ZrCrNi alloy on hydriding properties of $\mathrm{MgH}_{2}$. Int. J. Hydrogen Energy 2009, 34, 9157-9162. [CrossRef]

164. Wang, P.; Zhang, H.F.; Ding, B.Z.; Hu, Z.Q. Direct hydrogenation of Mg and decomposition behavior of the hydride formed. J. Alloy. Compd. 2000, 313, 209-213. [CrossRef]

165. Wang, P.; Wang, A.; Zhang, H.; Ding, B.; Hu, Z. Hydriding properties of a mechanically milled Mg-50 wt.\% $\mathrm{ZrFe}_{1.4} \mathrm{Cr}_{0.6}$ composite. J. Alloy. Compd. 2000, 297, 240-245. [CrossRef]

166. Agarwal, S.; Aurora, A.; Jain, A.; Montone, A. Structural and $\mathrm{H}_{2}$ sorption properties of $\mathrm{MgH}_{2}-10 \mathrm{wt} \% \mathrm{ZrCrM}$ $(\mathrm{M}=\mathrm{Cu}, \mathrm{Ni})$ nano-composites. J. Nanopart. Res. 2011, 13, 5719-5726. [CrossRef]

167. Jain, A.; Agarwal, S.; Jain, P.; Gislon, P.; Prosini, P.P.; Jain, I.P. Hydriding behavior of Mg-50 wt $\% \mathrm{ZrCrFe}$ composite Prepared by high energy ball milling. Int. J. Hydrogen Energy 2012, 37, 3665-3670. [CrossRef]

168. Jain, A.; Jain, P.; Agarwal, S.; Gislon, P.; Prosini, P.P.; Jain, I.P. Structural and Hydrogen Storage Properties Of Mg-x Wt\% ZrCrMn Composites. Adv. Mater. Lett. 2014, 5, 692-698. [CrossRef]

169. Agarwal, S.; Jain, A.; Jain, P.; Jangir, M.; Vyas, D.; Jain, I.P. Effect of ZrCrCo alloy on hydrogen storage properties of Mg. J. Alloy. Compd. 2015, 645, S518-S523. [CrossRef]

170. Molinas, B.; Ghilarducci, A.A.; Melnichuk, M.; Corso, H.L.; Peretti, H.A.; Agresti, F.; Bianchin, A.; Russo, S.L.; Maddalena, A.; Principi, G. Scaled-up production of a promising Mg-based hydride for hydrogen storage. Int. J. Hydrogen Energy 2009, 34, 4597-4601. [CrossRef]

171. Pighin, S.A.; Capurso, G.; Russo, S.L.; Peretti, H.A. Hydrogen sorption kinetics of magnesium hydride enhanced by the addition of $\mathrm{Zr}_{8} \mathrm{Ni}_{21}$ alloy. J. Alloy. Compd. 2012, 530, 111-115. [CrossRef]

172. Jia, Y.; Han, S.; Zhang, W.; Zhao, X.; Wang, J. Hydrogen absorption and desorption kinetics of $\mathrm{MgH}_{2}$ catalyzed by $\mathrm{MoS}_{2}$ and $\mathrm{MoO}_{2}$. Int. J. Hydrogen Energy 2013, 38, 2352-2356. [CrossRef]

173. Zhang, W.; Cheng, Y.; Han, D.; Han, S. The hydrogen storage properties of $\mathrm{MgH}_{2}-\mathrm{Fe}_{3} \mathrm{~S}_{4}$ composites. Energy 2015, 93, 625-630. [CrossRef]

174. Xie, X.; Chen, M.; Liu, P.; Shang, J.; Liu, T. High hydrogen desorption properties of Mg-based nanocomposite at moderate temperatures: The effects of multiple catalysts in situ formed by adding nickel sulfides/graphene. J. Power Sources 2017, 371, 112-118. [CrossRef]

175. Xie, X.; Ma, X.; Liu, P.; Shang, J.; Li, X.; Liu, T. Formation of Multiple-Phase Catalysts for the Hydrogen Storage of Mg Nanoparticles by Adding Flowerlike NiS. ACS Appl. Mater. Interfaces 2017, 9, 5937-5946. [CrossRef] [PubMed]

176. Zhang, W.; Xu, G.; Cheng, Y.; Chen, L.; Huo, Q.; Liu, S. Improved hydrogen storage properties of $\mathrm{MgH}_{2}$ by the addition of $\mathrm{FeS}_{2}$ micro-spheres. Dalton Trans. 2018, 47, 5217-5225. [CrossRef] [PubMed]

177. Milanese, C.; Garroni, S.; Gennari, F.; Marini, A.; Klassen, T.; Dornheim, M.; Pistidda, C. Solid State Hydrogen Storage in Alanates and Alanate-Based Compounds: A Review. Metals 2018, 8, 567. [CrossRef]

178. Liu, Y.; Ren, Z.; Zhang, X.; Jian, N.; Yang, Y.; Gao, M.; Pan, H. Development of Catalyst-Enhanced Sodium Alanate as an Advanced Hydrogen-Storage Material for Mobile Applications. Energy Technol. 2018, 6, 487-500. [CrossRef] 
179. Bogdanović, B.; Schwickardi, M. Ti-doped alkali metal aluminium hydrides as potential novel reversible hydrogen storage materials. J. Alloy. Compd. 1997, 253-254, 1-9. [CrossRef]

180. Bogdanović, B.; Sandrock, G. Catalyzed Complex Metal Hydrides. MRS Bull. 2002, 27, 712-716. [CrossRef]

181. Leon, A.; Kircher, O.; Rothe, J.; Fichtner, M. Chemical state and local structure around titanium atoms in NaAlH4 doped with TiCl3 using X-ray absorption spectroscopy. J. Phys. Chem. B 2004, 108, 16372-16376. [CrossRef]

182. Luo, W.; Gross, K.J. A kinetics model of hydrogen absorption and desorption in Ti-doped $\mathrm{NaAlH}_{4}$. J. Alloy. Compd. 2004, 385, 224-231. [CrossRef]

183. Gross, K.J.; Majzoub, E.H.; Spangler, S.W. The effects of titanium precursors on hydriding properties of alanates. J. Alloy. Compd. 2003, 356-357, 423-428. [CrossRef]

184. von Colbe, J.M.B.; Felderhoff, M.; Bogdanovic, B.; Schuth, F.; Weidenthaler, C. One-step direct synthesis of a Ti-doped sodium alanate hydrogen storage material. Chem. Commun. 2005, 37, 4732-4734. [CrossRef]

185. Onkawa, M.; Zhang, S.; Takeshita, H.T.; Kuriyama, N.; Kiyobayashi, T. Dehydrogenation kinetics of Ti-doped $\mathrm{NaAlH}_{4}$-Influence of Ti precursors and preparation methods. Int. J. Hydrogen Energy 2008, 33, 718-721. [CrossRef]

186. Paskevicius, M.; Filsø, U.; Karimi, F.; Puszkiel, J.; Pranjas, P.K.; Pistidda, C.; Armin, H.; Edmund, W.; Andreas, S.; Thomas, K.; et al. Cyclic stability and structure of nanoconfined Ti-doped $\mathrm{NaAlH}_{4}$. Int. J. Hydrogen Energy 2016, 41, 4159-4167. [CrossRef]

187. Resan, M.; Hampton, M.D.; Lomness, J.K.; Slattery, D.K. Effect of $\mathrm{Ti}_{\mathrm{x}} \mathrm{Al}_{\mathrm{y}}$ catalysts on hydrogen storage properties of $\mathrm{LiAlH}_{4}$ and $\mathrm{NaAlH}_{4}$. Int. J. Hydrogen Energy 2005, 30, 1417-1421. [CrossRef]

188. Lee, G.-J.; Kim, J.W.; Shim, J.-H.; Cho, Y.W.; Lee, K.S. Synthesis of ultrafine titanium aluminide powders and their catalytic enhancement in dehydrogenation kinetics of $\mathrm{NaAlH}_{4}$. Scr. Mater. 2007, 56, 125-128. [CrossRef]

189. Li, L.; Qiu, F.; Wang, Y.; Liu, G.; Yan, C.; An, C.; Xu, Y.; Wang, Y.; Song, D.; Jiao, L.; et al. Improved dehydrogenation performances of $\mathrm{TiB}_{2}$-doped sodium alanate. Mater. Chem. Phys. 2012, 134, 1197-1202. [CrossRef]

190. Chen, L.-X.; Fan, X.-L.; Xiao, X.-Z.; Xue, J.-W.; Li, S.-Q.; Ge, H.-W.; Chen, C.-P. Influence of TiC catalyst on absorption/desorption behaviors and microstructures of sodium aluminum hydride. Trans. Nonferr. Met. Soc. China 2011, 21, 1297-1302. [CrossRef]

191. Wu, R.; Du, H.; Wang, Z.; Gao, M.; Pan, H.; Liu, Y. Remarkably improved hydrogen storage properties of $\mathrm{NaAlH}_{4}$ doped with 2D titanium carbide. J. Power Sources 2016, 327, 519-525. [CrossRef]

192. Xiong, R.; Sang, G.; Zhang, G.; Yan, X.; Li, P.; Yao, Y.; Luo, D.; Chen, C.; Tang, T. Evolution of the active species and catalytic mechanism of Ti doped $\mathrm{NaAlH}_{4}$ for hydrogen storage. Int. J. Hydrogen Energy 2017, 42, 6088-6095. [CrossRef]

193. Liu, Y.; Wang, F.; Cao, Y.; Gao, M.; Pan, H.; Wang, Q. Mechanisms for the enhanced hydrogen desorption performance of the $\mathrm{TiF}_{4}$-catalyzed $\mathrm{Na}_{2} \mathrm{LiAlH}_{6}$ used for hydrogen storage. Energy Environ. Sci. 2010, 3, 645-653. [CrossRef]

194. Li, L.; Wang, Y.; Qiu, F.; Wang, Y.; Xu, Y.; An, C.; Jiao, L.; Yuan, H. Reversible hydrogen storage properties of $\mathrm{NaAlH}_{4}$ enhanced with TiN catalyst. J. Alloy. Compd. 2003, 356-357, 423-428. [CrossRef]

195. Lee, G.-J.; Shim, J.-H.; Cho, Y.W.; Lee, K.S. Improvement in desorption kinetics of $\mathrm{NaAlH}_{4}$ catalyzed with $\mathrm{TiO}_{2}$ nanopowder. Int. J. Hydrogen Energy 2008, 33, 3748-3753. [CrossRef]

196. Zhang, X.; Liu, Y.; Wang, K.; Gao, M.; Pan, H. Remarkably improved hydrogen storage properties of nanocrystalline $\mathrm{TiO}_{2}$-modified $\mathrm{NaAlH}_{4}$ and evolution of Ti-containing species during dehydrogenation/ hydrogenation. Nano Res. 2015, 8, 533-545. [CrossRef]

197. Pukazhselvan, D.; Sterlin, M.; Hudson, L.; Sinha, A.S.K.; Srivastava, O.N. Studies on metal oxide nanoparticles catalyzed sodium aluminum hydride. Energy 2010, 35, 5037-5042. [CrossRef]

198. Wang, P.; Jensen, C.M. Method for preparing Ti-doped $\mathrm{NaAlH}_{4}$ using Ti powder: Observation of an unusual reversible dehydrogenation behavior. J. Alloy. Compd. 2004, 379, 99-102. [CrossRef]

199. Wang, P.; Jensen, C.M. Preparation of Ti-Doped Sodium Aluminum Hydride from Mechanical Milling of $\mathrm{NaH} / \mathrm{Al}$ with Off-the-Shelf Ti Powder. J. Phys. Chem. B 2004, 108, 15827-15829. [CrossRef]

200. Zidan, R.A.; Takara, S.; Hee, A.G.; Jensen, C.M. Hydrogen cycling behavior of zirconium and titaniumzirconium-doped sodium aluminum hydride. J. Alloy. Compd. 1999, 285, 119-122. [CrossRef]

201. Wang, J.; Ebner, A.D.; Zidan, R.; Ritter, J.A. Synergistic effects of co-dopants on the dehydrogenation kinetics of sodium aluminum hydride. J. Alloy. Compd. 2005, 391, 245-255. [CrossRef] 
202. Bogdanović, B.; Felderhoff, M.; Pommerin, A.; Schüth, F.; Spielkamp, N. Advanced Hydrogen-Storage Materials Based on Sc-, Ce-, and Pr-Doped NaAlH 4 . Adv. Mater. 2006, 18, 1198-1201. [CrossRef]

203. Bogdanović, B.; Felderhoff, M.; Pommerin, A.; Schüth, F.; Spielkamp, N.; Stark, A. Cycling properties of Sc- and Ce-doped $\mathrm{NaAlH}_{4}$ hydrogen storage materials prepared by the one-step direct synthesis method. J. Alloy. Compd. 2005, 391, 245-255. [CrossRef]

204. Rongeat, C.; Scheerbaum, N.; Schultz, L.; Gutfleisch, O. Catalysis of $\mathrm{H}_{2}$ sorption in $\mathrm{NaAlH}_{4}$ : General description and new insights. Acta Mater. 2011, 59, 1725-1733. [CrossRef]

205. Fan, X.; Xiao, X.; Chen, L.; Yu, K.; Wu, Z.; Li, S.; Wang, Q. Active species of $\mathrm{CeAl}_{4}$ in the $\mathrm{CeCl}_{3}$-doped sodium aluminium hydride and its enhancement on reversible hydrogen storage performance. Chem. Commun. 2009, 44, 6857-6859. [CrossRef] [PubMed]

206. Fan, X.; Xiao, X.; Chen, L.; Li, S.; Ge, H.; Wang, Q. Enhanced Hydriding-Dehydriding Performance of $\mathrm{CeAl}_{2}$-Doped $\mathrm{NaAlH}_{4}$ and the Evolvement of Ce-Containing Species in the Cycling. J. Phys. Chem. C 2011, 115, 2537-2543. [CrossRef]

207. Fan, X.; Xiao, X.; Chen, L.; Li, S.; Ge, H.; Wang, Q. Thermodynamics, Kinetics, and Modeling Investigation on the Dehydrogenation of CeAl4-Doped $\mathrm{NaAlH}_{4}$ Hydrogen Storage Material. J. Phys. Chem. C 2011, 115, 22680-22687. [CrossRef]

208. Balema, V.P.; Wiench, J.W.; Dennis, K.W.; Pruski, M.; Pecharsky, V.K. Titanium catalyzed solid-state transformations in $\mathrm{LiAlH}_{4}$ during high-energy ball-milling. J. Alloy. Compd. 2001, 329, 108-114. [CrossRef]

209. Liu, X.; McGrady, G.S.; Langmi, H.W.; Jensen, C.M. Facile cycling of Ti-doped LiALH4 for high performance hydrogen storage. J. Am. Chem. Soc. 2009, 131, 5032-5033. [CrossRef]

210. Blanchard, D.; Brinks, H.W.; Hauback, B.C.; Norby, P. Desorption of $\mathrm{LiAlH}_{4}$ with Ti- and V-based additives. Mater. Sci. Eng. B 2004, 108, 54-59. [CrossRef]

211. Zang, L.; Cai, J.; Zhao, L.; Gao, W.; Liu, J.; Wang, Y. Improved hydrogen storage properties of $\mathrm{LiAlH}_{4}$ by mechanical milling with $\mathrm{TiF}_{3}$. J. Alloy. Compd. 2015, 647, 756-762. [CrossRef]

212. Resan, M.; Hampton, M.D.; Lomness, J.K.; Slattery, D.K. Effects of various catalysts on hydrogen release and uptake characteristics of $\mathrm{LiAlH}_{4}$. Int. J. Hydrogen Energy 2008, 33, 3748-3753.

213. Fernandez, J.R.A.; Aguey-Zinsou, F.; Elsaesser, M.; Ma, X.Z.; Bormann, R. Mechanical and thermal decomposition of $\mathrm{LiAlH}_{4}$ with metal halides. Int. J. Hydrogen Energy 2007, 32, 1033-1040. [CrossRef]

214. Kojima, Y.; Kawai, Y.; Matsumoto, M.; Haga, T. Hydrogen release of catalyzed lithium aluminum hydride by a mechanochemical reaction. J. Alloy. Compd. 2008, 462, 275-278. [CrossRef]

215. Cai, J.; Zang, L.; Zhao, L.; Liu, J.; Wang, Y. Dehydrogenation characteristics of $\mathrm{LiAlH}_{4}$ improved by in-situ formed catalysts. J. Energy Chem. 2016, 25, 868-873. [CrossRef]

216. Cao, Z.; Ma, X.; Wang, H.; Ouyang, L. Catalytic effect of $\mathrm{ScCl}_{3}$ on the dehydrogenation properties of $\mathrm{LiAlH}_{4}$. J. Alloy. Compd. 2018, 762, 73-79. [CrossRef]

217. Ismail, M.; Zhao, Y.; Yu, X.B.; Dou, S.X. Effects of $\mathrm{NbF}_{5}$ addition on the hydrogen storage properties of $\mathrm{LiAlH}_{4}$. Int. J. Hydrogen Energy 2010, 35, 2361-2367. [CrossRef]

218. Sun, T.; Huang, C.K.; Wang, H.; Sun, L.X.; Zhu, M. The effect of doping $\mathrm{NiCl}_{2}$ on the dehydrogenation properties of $\mathrm{LiAlH}_{4}$. Int. J. Hydrogen Energy 2008, 33, 6216-6221. [CrossRef]

219. Ismail, M.; Sinin, A.M.; Sheng, C.K.; Nik, W.B.W. Desorption Behaviours of Lithium Alanate with Metal Oxide Nanopowder Additives. Int. J. Electrochem. Sci. 2014, 9, 4959-4973.

220. Qu, X.; Li, P.; Zhang, L.; Ahmad, M. Hydrogen Sorption Improvement of $\mathrm{LiAlH}_{4}$ Catalyzed by $\mathrm{Nb}_{2} \mathrm{O}_{5}$ and $\mathrm{Cr}_{2} \mathrm{O}_{3}$ Nanoparticles. J. Phys. Chem. C 2011, 115, 13088-13099.

221. Liu, S.; Ma, Q.; Zheng, X.; Fang, X.; Guo, X.; Zheng, X. Influences of $\mathrm{Y}_{2} \mathrm{O}_{3}$ Doping on Hydrogen Release Property of $\mathrm{LiAlH}_{4}$. Rare Metal Mater. Eng. 2014, 43, 0287-0290.

222. Ismail, M.; Zhao, Y.; Yu, X.B.; Ranjbar, A.; Dou, S.X. Improved hydrogen desorption in lithium alanate by addition of SWCNT-metallic catalyst composite. Int. J. Hydrogen Energy 2011, 36, 3593-3599. [CrossRef]

223. Hsu, W.-C.; Yang, C.-H.; Tsai, W.-T. Catalytic effect of MWCNTs on the dehydrogenation behavior of $\mathrm{LiAlH}_{4}$. Int. J. Hydrogen Energy 2014, 39, 927-933. [CrossRef]

224. Wang, L.; Rawal, A.; Quadir, M.Z.; Aguey-Zinsou, K.-F. Nanoconfined lithium aluminium hydride $\left(\mathrm{LiAlH}_{4}\right)$ and hydrogen reversibility. Int. J. Hydrogen Energy 2017, 42, 14144-14153. [CrossRef]

225. Liu, Y.; Liang, C.; Zhou, H.; Gao, M.; Pan, H.; Wang, Q. A novel catalyst precursor $\mathrm{K}_{2} \mathrm{TiF}_{6}$ with remarkable synergetic effects of $\mathrm{K}, \mathrm{Ti}$ and $\mathrm{F}$ together on reversible hydrogen storage of $\mathrm{NaAlH}_{4}$. Chem. Commun. 2011, 47, 1740-1742. [CrossRef] [PubMed] 
226. Li, Z.; Liu, S.; Si, X.; Zhang, J.; Jiao, C.; Wang, S. Significantly improved dehydrogenation of $\mathrm{LiAlH}_{4}$ destabilized by $\mathrm{K}_{2} \mathrm{TiF}_{6}$. Int. J. Hydrogen Energy 2012, 37, 3261-3267. [CrossRef]

227. Wan, Q.; Li, P.; Li, Z.; Zhao, K.; Liu, Z.; Wang, L. NaAlH 4 dehydrogenation properties enhanced by $\mathrm{MnFe}_{2} \mathrm{O}_{4}$ nanoparticles. J. Power Sources 2014, 248, 388-395. [CrossRef]

228. Zhai, F.; Li, P.; Sun, A.; Wu, S.; Wan, Q.; Zhang, W.; Li, Y.; Cui, L.; Qu, X. Significantly Improved Dehydrogenation of $\mathrm{LiAlH}_{4}$ Destabilized by $\mathrm{MnFe}_{2} \mathrm{O}_{4}$ Nanoparticles. J. Phys. Chem. C 2012, 116, 11939-11945. [CrossRef]

229. Huang, Y.; Li, P.; Wan, Q.; Zhang, J.; Li, Y.; Li, R.; Dong, X.; Qu, X. Improved dehydrogenation performance of $\mathrm{NaAlH} 4$ using $\mathrm{NiFe}_{2} \mathrm{O}_{4}$ nanoparticles. J. Alloy. Compd. 2017, 709, 850-856. [CrossRef]

230. Li, L.; An, C.; Wang, Y.; Xu, Y.; Qiu, F.; Wang, Y.; Jiao, L.; Yuan, H. Enhancement of the $\mathrm{H}_{2}$ desorption properties of $\mathrm{LiAlH}_{4}$ doping with $\mathrm{NiCo}_{2} \mathrm{O}_{4}$ nanorods. Int. J. Hydrogen Energy 2014, 39, 4414-4420. [CrossRef]

231. Zhang, T.; Isobe, S.; Wang, Y.; Oka, H.; Hashimoto, N.; Ohnuki, S. A metal-oxide catalyst enhanced the desorption properties in complex metal hydrides. J. Mater. Chem. A 2014, 2, 4361-4365. [CrossRef]

232. Frankcombe, T.J. Proposed Mechanisms for the Catalytic Activity of Ti in $\mathrm{NaAlH}_{4}$. Chem. Rev. 2012, 112, 2164-2178. [CrossRef]

233. Ivanov, E.; Konstanchuk, I.; Stepanov, A.; Boldyrev, V. Magnesium mechanical alloys for hydrogen storage. J. Less Common Met. 1987, 131, 25-29. [CrossRef]

234. Fichtner, M.; Fuhr, O.; Kircher, O.; Rothe, J. Small Ti clusters for catalysis of hydrogen exchange in NaAlH4. Nanotechnology 2003, 14, 778. [CrossRef]

235. Fichtner, M.; Engel, J.; Fuhr, O.; Kircher, O.; Rubner, O. Nanocrystalline aluminium hydrides for hydrogen storage. Mater. Sci. Eng. B 2004, 108, 42-47. [CrossRef]

236. Kircher, O.; Fichtner, M. Hydrogen exchange kinetics in $\mathrm{NaAlH}_{4}$ catalyzed in different decomposition states. J. Appl. Phys. 2014, 95, 7748. [CrossRef]

237. Sun, D.; Srinivasan, S.S.; Chen, G.; Jensen, C.M. Rehydrogenation and cycling studies of dehydrogenated $\mathrm{NaAlH}_{4}$. J. Alloy. Compd. 2004, 373, 265-269. [CrossRef]

238. Singh, S.; Eijt, S.W.H.; Huot, J.; Kockelmann, W.A.; Wagemaker, M.; Mulder, F.M. The $\mathrm{TiCl}_{3}$ catalyst in $\mathrm{NaAlH}_{4}$ for hydrogen storage induces grain refinement and impacts on hydrogen vacancy formation. Acta Mater. 2007, 55, 5549-5557. [CrossRef]

239. Chen, J.; Kuriyama, N.; Xu, Q.; Takeshita, H.T.; Sakai, T. Reversible Hydrogen Storage via Titanium-Catalyzed $\mathrm{LiAlH}_{4}$ and $\mathrm{Li}_{3} \mathrm{AlH}_{6}$. J. Phys. Chem. B 2001, 105, 11214-11220. [CrossRef]

240. Chen, J.; Kuriyama, N.; Takeshita, H.T.; Sakai, T. Nanocrystalline Ti-doped $\mathrm{Li}_{3} \mathrm{AlH}_{6}$ as a Reversible Hydrogen Storage Material. Adv. Eng. Mater. 2001, 3, 695-698. [CrossRef]

241. Sandrock, G.; Gross, K.; Thomas, G. Effect of Ti-catalyst content on the reversible hydrogen storage properties of the sodium alanates. J. Alloy. Compd. 2002, 339, 299-308. [CrossRef]

242. Wang, P.; Kang, X.-D.; Cheng, H.-M. Exploration of the Nature of Active Ti Species in Metallic Ti-Doped $\mathrm{NaAlH}_{4}$. J. Phys. Chem. B 2005, 109, 20131-20136. [CrossRef]

243. Blomqvist, A.; Araújo, C.M.; Jena, P.; Ahuja, R. Dehydrogenation from 3d-transition-metal-doped NaAlH : $^{2}$ Prediction of catalysts. Appl. Phys. Lett. 2007, 90, 141904. [CrossRef]

244. Bai, K.; Wu, P. Role of Ti in the reversible dehydrogenation of Ti-doped sodium alanate. Appl. Phys. Lett. 2006, 89, 201904. [CrossRef]

245. Araújo, C.M.; Ahuja, R.; Guillén, J.M.O. Role of titanium in hydrogen desorption in crystalline sodium alanate. Appl. Phys. Lett. 2005, 86, 251913. [CrossRef]

246. Gross, K.J.; Guthrie, S.; Takara, S.; Thomas, G. In-situ X-ray diffraction study of the decomposition of $\mathrm{NaAlH}_{4}$. J. Alloy. Compd. 2000, 297, 270-281. [CrossRef]

247. Zhang, J.; Zhu, J.; Chen, G.; Sun, D.; He, B.; Wei, Z.; Wei, S. Nature and Role of Ti Species in the Hydrogenation of a NaH/Al Mixture. J. Phys. Chem. C 2007, 111, 3476-3479.

248. Fu, Q.J.; Ramirez-Cuesta, A.J.; Tsang, S.C. Molecular Aluminum Hydrides Identified by Inelastic Neutron Scattering during $\mathrm{H}_{2}$ Regeneration of Catalyst-Doped $\mathrm{NaAlH}_{4}$. J. Phys. Chem. B 2006, 110, 711-715. [CrossRef] [PubMed]

249. Walters, R.T.; Scogin, J.H. A reversible hydrogen storage mechanism for sodium alanate: The role of alanes and the catalytic effect of the dopant. J. Alloy. Compd. 2004, 379, 135-142. [CrossRef] 
250. Ivancic, T.M.; Hwang, S.-J.; Bowman, R.C., Jr.; Birkmire, D.S.; Jensen, C.M.; Udovic, T.J.; Conradi, M.S. Discovery of A New Al Species in Hydrogen Reactions of $\mathrm{NaAlH}_{4}$. J. Phys. Chem. Lett. 2010, 1, 2412-2416. [CrossRef]

251. Gunaydin, H.; Houk, K.N.; Ozolinš, V. Vacancy-mediated dehydrogenation of sodium alanate. Proc. Natl. Acad. Sci. USA 2008, 105, 3673-3677. [CrossRef] [PubMed]

252. Borgschulte, A.; Züttel, A.; Hug, P.; Barkhordarian, G.; Eigen, N.; Dornheim, M.; Bormann, R.; Ramirez-Cuesta, A.J. Hydrogen-deuterium exchange experiments to probe the decomposition reaction of sodium alanate. Phys. Chem. Chem. Phys. 2008, 10, 4045-4055. [CrossRef] [PubMed]

253. Peles, A.; Van de Walle, C.G. Role of charged defects and impurities in kinetics of hydrogen storage materials: A first-principles study. Phys. Rev. B 2007, 76, 214101. [CrossRef]

254. Marashdeh, A.; Olsen, R.A.; Løvvik, O.M.; Kroes, G.-J. Density Functional Theory Study of the $\mathrm{TiH}_{2}$ Interaction with a $\mathrm{NaAlH}_{4}$ Cluster. J. Phys. Chem. C 2008, 112, 15759-15764. [CrossRef]

255. Atakli, Z.Ö.K.; Callini, E.; Kato, S.; Mauron, P.; Orimo, S.-I.; Züttel, A. The catalyzed hydrogen sorption mechanism in alkali alanates. Phys. Chem. Chem. Phys. 2015, 17, 20932-20940. [CrossRef] [PubMed]

256. Ohba, N.; Miwa, K.; Aoki, M.; Noritake, T.; Towata, S.; Nakamori, Y.; Orimo, S.; Züttel, A. First-principles study on the stability of intermediate compounds of $\mathrm{LiBH}_{4}$. Phys. Rev. B 2006, 74, 075110. [CrossRef]

257. Nakamori, Y.; Li, H.-W.; Kikuchi, K.; Aoki, M.; Miwa, K.; Towata, S.; Orimo, S. Thermodynamical stabilities of metal-borohydrides. J. Alloy. Compd. 2007, 446-447, 296-300. [CrossRef]

258. Paskevicius, M.; Jepsen, L.H.; Schouwink, P.; Černý, R.; Ravnsbæk, D.B.; Filinchuk, Y.; Martin, D.; Flemming, B.; Torben, R.J. Metal borohydrides and derivatives-Synthesis, structure and properties. Chem. Soc. Rev. 2017, 46, 1565-1634. [CrossRef] [PubMed]

259. Yu, X.B.; Wu, Z.; Chen, Q.R.; Li, Z.L.; Weng, B.C.; Huang, T.S. Improved hydrogen storage properties of $\mathrm{LiBH}_{4}$ destabilized by carbon. Appl. Phys. Lett. 2007, 90, 034106. [CrossRef]

260. Jiang, Z.; Yuan, J.; Han, H.; Wu, Y. Effect of carbon nanotubes on the microstructural evolution and hydrogen storage properties of $\mathrm{Mg}\left(\mathrm{BH}_{4}\right)_{2}$. J. Alloy. Compd. 2018, 743, 11-16. [CrossRef]

261. Fang, Z.-Z.; Kang, X.-D.; Wang, P. Improved hydrogen storage properties of $\mathrm{LiBH}_{4}$ by mechanical milling with various carbon additives. Int. J. Hydrogen Energy 2010, 35, 8247-8252. [CrossRef]

262. Xu, J.; Meng, R.; Cao, J.; Gu, X.; Qi, Z.; Wang, W.; Chen, Z. Enhanced dehydrogenation and rehydrogenation properties of $\mathrm{LiBH}_{4}$ catalyzed by graphene. Int. J. Hydrogen Energy 2013, 38, 2796-2803. [CrossRef]

263. Zhang, L.; Xiao, X.; Fan, X.; Li, S.; Ge, H.; Wang, Q.; Chen, L. Fast hydrogen release under moderate conditions from NaBH4 destabilized by fluorographite. RSC Adv. 2014, 4, 2550-2556. [CrossRef]

264. Zhang, W.; Xu, G.; Chen, L.; Pan, S.; Jing, X.; Wang, J.; Han, S. Enhanced hydrogen storage performances of $\mathrm{LiBH}_{4}$ modified with three-dimensional porous fluorinated graphene. Int. J. Hydrogen Energy 2017, 42, 15262-15270. [CrossRef]

265. Guo, L.; Li, Y.; Ma, Y.; Liu, Y.; Peng, D.; Zhang, L.; Han, S. Enhanced hydrogen storage capacity and reversibility of $\mathrm{LiBH}_{4}$ encapsulated in carbon nanocages. Int. J. Hydrogen Energy 2017, 42, 2215-2222. [CrossRef]

266. Xua, J.; Meng, R.; Cao, J.; Gu, X.; Song, W.-L.; Qi, Z.; Wang, W.; Chen, Z. Graphene-supported Pd catalysts for reversible hydrogen storage in $\mathrm{LiBH}_{4}$. J. Alloy. Compd. 2013, 564, 84-90. [CrossRef]

267. Sun, T.; Xiao, F.; Tang, R.; Wang, Y.; Dong, H.; Li, Z. Hydrogen storage performance of nano Ni decorated $\mathrm{LiBH}_{4}$ on activated carbon prepared through organic solvent. J. Alloy. Compd. 2014, 612, 287-292. [CrossRef]

268. Wahab, M.A.; Young, D.J.; Karim, A.; Fawzia, S.; Beltramini, J.N. Low-temperature hydrogen desorption from $\mathrm{Mg}\left(\mathrm{BH}_{4}\right)_{2}$ catalysed by ultrafine Ni nanoparticles in a mesoporous carbon matrix. Int. J. Hydrogen Energy 2016, 41, 20573-20582. [CrossRef]

269. Xia, G.L.; Guo, Y.H.; Wu, Z.; Yu, X.B. Enhanced hydrogen storage performance of $\mathrm{LiBH}_{4}-\mathrm{Ni}$ composite. J. Alloy. Compd. 2009, 479, 545-548. [CrossRef]

270. Au, M.; Jurgensen, A.; Zeigler, K. Modified Lithium Borohydrides for Reversible Hydrogen Storage (2). J. Phys. Chem. B 2006, 110, 26482-26487. [CrossRef] [PubMed]

271. Yang, J.; Sudik, A.; Wolverton, C. Destabilizing $\mathrm{LiBH}_{4}$ with a Metal (M = Mg, Al, Ti, V, Cr, or Sc) or Metal Hydride $\left(\mathrm{MH}_{2}=\mathrm{MgH}_{2}, \mathrm{TiH}_{2}\right.$, or $\left.\mathrm{CaH}_{2}\right)$. J. Phys. Chem. C 2007, 111, 19134-19140. [CrossRef]

272. Pendolino, F.; Mauron, P.; Borgschulte, A.; Züttel, A. Effect of Boron on the Activation Energy of the Decomposition of $\mathrm{LiBH}_{4}$. J. Phys. Chem. C 2009, 113, 17231-17234. [CrossRef] 
273. Züttel, A.; Rentsch, S.; Fischer, P.; Wenger, P.; Sudan, P.; Mauron, P.; Emmenegger, C. Hydrogen storage properties of $\mathrm{LiBH}_{4}$. J. Alloy. Compd. 2003, 356-357, 515-520.

274. Au, M.; Jurgensen, A. Modified Lithium Borohydrides for Reversible Hydrogen Storage. J. Phys. Chem. B 2006, 110, 7062-7067. [CrossRef]

275. Yu, X.B.; Grant, D.M.; Walker, G.S. Low-Temperature Dehydrogenation of $\mathrm{LiBH}_{4}$ through Destabilization with $\mathrm{TiO}_{2}$. J. Phys. Chem. C 2008, 112, 11059-11062. [CrossRef]

276. Au, M.; Spencer, W.; Jurgensen, A.; Zeigler, C. Hydrogen storage properties of modified lithium borohydrides. J. Alloy. Compd. 2008, 462, 303-309. [CrossRef]

277. Mosegaard, L.; Møller, B.; Jørgensen, J.-E.; Filinchuk, Y.; Cerenius, Y.; Hanson, J.C.; Dimasi, E.; Besenbacher, F.; Jensen, T.R. Reactivity of $\mathrm{LiBH}_{4}$ : In Situ Synchrotron Radiation Powder X-ray Diffraction Study. J. Phys. Chem. C 2008, 112, 1299-1303. [CrossRef]

278. Yu, X.B.; Grant, D.M.; Walker, G.S. Dehydrogenation of $\mathrm{LiBH}_{4}$ Destabilized with Various Oxides. J. Phys. Chem. C 2009, 113, 17945-17949. [CrossRef]

279. Ploysuksai, W.; Rangsunvigit, P.; Kulprathipanja, S. Effects of $\mathrm{TiO}_{2}$ and $\mathrm{Nb}_{2} \mathrm{O}_{5}$ on Hydrogen desorption of $\mathrm{Mg}\left(\mathrm{BH}_{4}\right)_{2}$. Int. J. Mater. Metall. Eng. 2012, 6, 311-315.

280. Zavorotynska, O.; Saldan, I.; Hino, S.; Humphries, T.D.; Deledda, S.; Hauback, B.C. Hydrogen cycling in $\gamma-\mathrm{Mg}\left(\mathrm{BH}_{4}\right)_{2}$ with cobalt-based additives. J. Mater. Chem. A 2015, 3, 6592-6602. [CrossRef]

281. Saldan, I.; Frommen, C.; Llamas-Jansa, I.; Kalantzopoulos, G.N.; Hino, S.; Arstad, B.; Heyn, R.H.; Zavorotynska, O.; Deledda, S.; Sørby, M.H. Hydrogen storage properties of $\gamma-\mathrm{Mg}\left(\mathrm{BH}_{4}\right)_{2}$ modified by $\mathrm{MoO}_{3}$ and $\mathrm{TiO}_{2}$. Int. J. Hydrogen Energy 2015, 40, 12286-12293. [CrossRef]

282. Xu, X.; Zang, L.; Zhao, Y.; Zhao, Y.; Wang, Y.; Jiao, L. Hydrogen storage behavior of $\mathrm{LiBH}_{4}$ improved by the confinement of hierarchical porous $\mathrm{ZnO} / \mathrm{ZnCo}_{2} \mathrm{O}_{4}$ nanoparticles. J. Power Sources 2017, 359, 134-141. [CrossRef]

283. Zhao, Y.; Liu, H.; Liu, Y.; Wang, Y.; Yuan, H.; Jiao, L. Synergistic effects of destabilization, catalysis and nanoconfinement on dehydrogenation of $\mathrm{LiBH}_{4}$. Int. J. Hydrogen Energy 2017, 42, 1354-1360. [CrossRef]

284. Au, M.; Walters, R.T. Reversibility aspect of lithium borohydrides. Int. J. Hydrogen Energy 2010, 35, 10311-10316. [CrossRef]

285. Zhang, B.J.; Liu, B.H. Hydrogen desorption from $\mathrm{LiBH}_{4}$ destabilized by chlorides of transition metal $\mathrm{Fe}, \mathrm{Co}$, and Ni. Int. J. Hydrogen Energy 2010, 35, 7288-7294. [CrossRef]

286. Newhouse, R.J.; Stavila, V.; Hwang, S.-J.; Klebanoff, L.E.; Zhang, J.Z. Reversibility and Improved Hydrogen Release of Magnesium Borohydride. J. Phys. Chem. C 2010, 114, 5224-5232. [CrossRef]

287. Bardají, E.G.; Hanada, N.; Zabara, O.; Fichtner, M. Effect of several metal chlorides on the thermal decomposition behaviour of $\alpha-\mathrm{Mg}\left(\mathrm{BH}_{4}\right)_{2}$. Int. J. Hydrogen Energy 2011, 36, 12313-12318. [CrossRef]

288. Mao, J.; Guo, Z.; Nevirkovets, I.P.; Liu, H.K.; Dou, S.X. Hydrogen De-/Absorption Improvement of $\mathrm{NaBH}_{4}$ Catalyzed by Titanium-Based Additives. J. Phys. Chem. C 2012, 116, 1596-1604. [CrossRef]

289. Al-Kukhun, A.; Hwang, H.T.; Varma, A. $\mathrm{NbF}_{5}$ additive improves hydrogen release from magnesium borohydride. Int. J. Hydrogen Energy 2012, 37, 17671-17677. [CrossRef]

290. Zhang, Z.G.; Wang, H.; Liu, J.W.; Zhu, M. Thermal decomposition behaviors of magnesium borohydride doped with metal fluoride additives. Thermochim. Acta 2013, 560, 82-88. [CrossRef]

291. Paduani, C.; Jena, P. Role of Ti-based catalysts in the dehydrogenation mechanism of magnesium borohydride: A cluster approach. Int. J. Hydrogen Energy 2013, 38, 2357-2362. [CrossRef]

292. Humphries, T.D.; Kalantzopoulos, G.N.; Llamas-Jansa, I.; Olsen, J.E.; Hauback, B.C. Reversible Hydrogenation Studies of $\mathrm{NaBH}_{4}$ Milled with Ni-Containing Additives. J. Phys. Chem. C 2013, 117, 6060-6065. [CrossRef]

293. Chong, L.; Zou, J.; Zeng, X.; Ding, W. Mechanisms of reversible hydrogen storage in $\mathrm{NaBH}_{4}$ through $\mathrm{NdF}_{3}$ addition. J. Mater. Chem. A 2013, 1, 3983-3991. [CrossRef]

294. Chong, L.; Zou, J.; Zeng, X.; Ding, W. Reversible hydrogen sorption in $\mathrm{NaBH}_{4}$ at lower temperatures. J. Mater. Chem. A 2013, 1, 13510-13523. [CrossRef]

295. Zou, J.; Li, L.; Zeng, X.; Ding, W. Reversible hydrogen storage in a $3 \mathrm{NaBH}_{4} / \mathrm{YF}_{3}$ composite. Int. J. Hydrogen Energy 2012, 37, 17118-17125. [CrossRef]

296. Saldan, I.; Hino, S.; Humphries, T.D.; Zavorotynska, O.; Chong, M.; Jensen, C.M.; Deledda, S.; Hauback, B.C. Structural Changes Observed during the Reversible Hydrogenation of $\mathrm{Mg}\left(\mathrm{BH}_{4}\right)_{2}$ with Ni-Based Additives. J. Phys. Chem. C 2014, 118, 23376-23384. [CrossRef] 
297. Chong, L.; Zou, J.; Zeng, X.; Ding, W. Study on reversible hydrogen sorption behaviors of a $3 \mathrm{NaBH}_{4} / \mathrm{HoF}_{3}$ composite. Int. J. Hydrogen Energy 2014, 39, 14275-14281. [CrossRef]

298. Tu, G.; Xiao, X.; Jiang, Y.; Qin, T.; Li, S.; Ge, H.; Wang, Q.; Chen, L. Composite cooperative enhancement on the hydrogen desorption kinetics of $\mathrm{LiBH}_{4}$ by co-doping with $\mathrm{NbCl}_{5}$ and hexagonal BN. Int. J. Hydrogen Energy 2015, 33, 10527-10535. [CrossRef]

299. Zhou, H.; Zhang, L.; Gao, S.; Liu, H.; Xu, L.; Wang, X.; Yan, M. Hydrogen storage properties of activated carbon confined $\mathrm{LiBH}_{4}$ doped with $\mathrm{CeF}_{3}$ as catalyst. Int. J. Hydrogen Energy 2017, 42, 23010-23017. [CrossRef]

300. Kumar, S.; Singh, A.; Nakajima, K.; Jain, A.; Miyaoka, H.; Ichikawa, T.; Dey, G.K.; Kojima, Y. Improved hydrogen release from magnesium borohydride by $\mathrm{ZrCl}_{4}$ additive. Int. J. Hydrogen Energy 2017, 42, 22342-22347. [CrossRef]

301. Kumar, S.; Jain, A.; Miyaoka, H.; Ichikawa, T.; Kojima, Y. Study on the thermal decomposition of $\mathrm{NaBH}_{4}$ catalyzed by $\mathrm{ZrCl}_{4}$. Int. J. Hydrogen Energy 2017, 42, 22432-22437. [CrossRef]

302. Zhao, S.X.; Wang, C.Y.; Liu, D.M.; Tan, Q.J.; Li, Y.T.; Si, T.Z. Destabilization of $\mathrm{LiBH}_{4}$ by $\mathrm{SrF}_{2}$ for reversible hydrogen storage. Int. J. Hydrogen Energy 2018, 43, 5098-5103. [CrossRef]

303. Zhao, N.; Zou, J.; Zeng, X.; Ding, W. Mechanisms of partial hydrogen sorption reversibility in a $3 \mathrm{NaBH}_{4} / \mathrm{ScF}_{3}$ composite. RSC Adv. 2018, 8, 9211-9217. [CrossRef]

304. Chen, P.; Xiong, Z.; Luo, J.; Lin, J.; Tan, K.L. Interaction of hydrogen with metal nitrides and imides. Nature 2002, 420, 302-304. [CrossRef] [PubMed]

305. Ichikawa, T.; Isobe, S.; Hanada, N.; Fujii, H. Lithium nitride for reversible hydrogen storage. J. Alloy. Compd. 2004, 365, 271-276. [CrossRef]

306. Ichikawa, T.; Hanada, N.; Isobe, S.; Leng, H.Y.; Fujii, H. Hydrogen storage properties in Ti catalyzed Li-N-H system. J. Alloy. Compd. 2005, 404-406, 435-438. [CrossRef]

307. Matsumoto, M.; Haga, T.; Kawai, Y.; Kojima, Y. Hydrogen desorption reactions of Li-N-H hydrogen storage system: Estimation of activation free energy. J. Alloy. Compd. 2007, 439, 358-362. [CrossRef]

308. Albanesi, L.F.; Larochette, P.A.; Gennari, F.C. Destabilization of the $\mathrm{LiNH}_{2}-\mathrm{LiH}$ hydrogen storage system by aluminum incorporation. Int. J. Hydrogen Energy 2013, 38, 12325-12334. [CrossRef]

309. Albanesia, L.F.; Garroni, S.; Larochette, P.A.; Nolis, P.; Mulas, G.; Enzo, S.; Baró, M.D.; Gennari, F.C. Role of aluminum chloride on the reversible hydrogen storage properties of the $\mathrm{Li}-\mathrm{N}-\mathrm{H}$ system. Int. J. Hydrogen Energy 2015, 39, 13506-13517. [CrossRef]

310. Lin, H.-J.; Li, H.-W.; Murakami, H.; Akiba, E. Remarkably improved hydrogen storage properties of $\mathrm{LiNH}_{2}-\mathrm{LiH}$ composite via the addition of $\mathrm{CeF}_{4}$. J. Alloy. Compd. 2018, 735, 1017-1022. [CrossRef]

311. Leng, H.; Wu, Z.; Duan, W.; Xia, G.; Li, Z. Effect of $\mathrm{MgCl}_{2}$ additives on the H-desorption properties of Li-N-H system. Int. J. Hydrogen Energy 2012, 37, 903-907. [CrossRef]

312. Price, C.; Gray, J.; Lascola, R.; Anton, D.L. The effects of halide modifiers on the sorption kinetics of the Li-Mg-N-H System. Int. J. Hydrogen Energy 2012, 37, 2742-2749. [CrossRef]

313. Bill, R.F.; Reed, D.; Book, D.; Anderson, P.A. Effect of the calcium halides, $\mathrm{CaCl}_{2}$ and $\mathrm{CaBr}_{2}$, on hydrogen desorption in the Li-Mg-N-H system. J. Alloy. Compd. 2015, 645, S96-S99. [CrossRef]

314. Nayebossadri, S.; Aguey-Zinsou, K.F.; Guo, Z.X. Effect of nitride additives on Li-N-H hydrogen storage system. Int. J. Hydrogen Energy 2011, 36, 7920-7926. [CrossRef]

315. Xiong, Z.; Wu, G.; Hu, J.; Chen, P. Ternary Imides for Hydrogen Storage. Adv. Mater. 2004, 16, $1522-1525$. [CrossRef]

316. Leng, H.Y.; Ichikawa, T.; Hino, S.; Hanada, N.; Isobe, S.; Fujii, H. New Metal-N-H System Composed of $\mathrm{Mg}\left(\mathrm{NH}_{2}\right)_{2}$ and LiH for Hydrogen Storage. J. Phys. Chem. B 2004, 108, 8763-8765. [CrossRef]

317. Nakamori, Y.; Kitahara, G.; Orimo, S. Synthesis and dehydriding studies of Mg-N-H systems. J. Power Sources 2004, 138, 309-312. [CrossRef]

318. Ma, L.-P.; Dai, H.-B.; Liang, Y.; Kang, X.-D.; Fang, Z.-Z.; Wang, P.-J.; Wang, P.; Cheng, H.-M. Catalytically Enhanced Hydrogen Storage Properties of $\mathrm{Mg}\left(\mathrm{NH}_{2}\right)_{2}+2 \mathrm{LiH}$ Material by Graphite-Supported $\mathrm{Ru}$ Nanoparticles. J. Phys. Chem. C 2008, 112, 18280-18285. [CrossRef]

319. Shahi, R.R.; Yadav, T.P.; Shaz, M.A.; Srivastva, O.N. Studies on dehydrogenation characteristic of $\mathrm{Mg}\left(\mathrm{NH}_{2}\right)_{2} / \mathrm{LiH}$ mixture admixed with vanadium and vanadium based catalysts $\left(\mathrm{V}, \mathrm{V}_{2} \mathrm{O}_{5}\right.$ and $\left.\mathrm{VCl}_{3}\right)$. Int. J. Hydrogen Energy 2010, 35, 238-246. [CrossRef]

320. Anton, D.L.; Price, C.J.; Gray, J. Affects of Mechanical Milling and Metal Oxide Additives on Sorption Kinetics of 1:1 $\mathrm{LiNH}_{2} / \mathrm{MgH}_{2}$ Mixture. Energies 2011, 4, 826-844. [CrossRef] 
321. Hu, J.; Poh, A.; Wang, S.; Rothe, J.; Fichtner, M. Additive Effects of $\mathrm{LiBH}_{4}$ and $\mathrm{ZrCoH}_{3}$ on the Hydrogen Sorption of the Li-Mg-N-H Hydrogen Storage System. J. Phys. Chem. C 2012, 116, 20246-20253. [CrossRef]

322. Ulmer, U.; Hu, J.; Franzreb, M.; Fichtner, M. Preparation, scale-up and testing of nanoscale, doped amide systems for hydrogen storage. Int. J. Hydrogen Energy 2013, 38, 1439-1449. [CrossRef]

323. Li, C.; Liu, Y.; Gu, Y.; Gao, M.; Pan, H. Improved Hydrogen-Storage Thermodynamics and Kinetics for an $\mathrm{RbF}-$ Doped $\mathrm{Mg}\left(\mathrm{NH}_{2}\right)_{2}-2 \mathrm{LiH}$ System. Chem. Asian J. 2013, 8, 2136-2143. [CrossRef]

324. Demirocak, D.E.; Srinivasan, S.S.; Ram, M.K.; Kuhn, J.N.; Muralidharan, R.; Li, X.; Goswami, D.Y.; Stefanakos, E.K. Reversible hydrogen storage in the $\mathrm{Li}-\mathrm{Mg}-\mathrm{N}-\mathrm{H}$ system-The effects of Ru doped single walled carbon nanotubes on NH3 emission and kinetics. Int. J. Hydrogen Energy 2013, 38, 10039-10049. [CrossRef]

325. Yan, M.-y.; Sun, F.; Liu, X.-p.; Ye, J.-h. Effects of compaction pressure and graphite content on hydrogen storage properties of $\mathrm{Mg}\left(\mathrm{NH}_{2}\right)_{2}-2 \mathrm{LiH}$ hydride. Int. J. Hydrogen Energy 2014, 39, 19656-19661. [CrossRef]

326. Wang, J.; Liu, T.; Wu, G.; Li, W.; Liu, Y.; Araújo, C.M. Potassium-Modified Mg( $\left.\mathrm{NH}_{2}\right)_{2} / 2 \mathrm{LiH}$ System for Hydrogen Storage. Angew. Chem. Int. Ed. 2009, 48, 5828-5832. [CrossRef]

327. Teng, Y.-L.; Ichikawa, T.; Miyaoka, H.; Kojima, Y. Improvement of hydrogen desorption kinetics in the $\mathrm{LiH}_{-} \mathrm{NH}_{3}$ system by addition of KH. Chem. Commun. 2011, 47, 12227-12229. [CrossRef] [PubMed]

328. Durojaiye, T.; Goudy, A. Desorption kinetics of lithium amide/magnesium hydride systems at constant pressure thermodynamic driving forces. Int. J. Hydrogen Energy 2012, 37, 3298-3304. [CrossRef]

329. Luo, W.; Stavila, V.; Klebanoff, L.E. New insights into the mechanism of activation and hydrogen absorption of $\left(2 \mathrm{LiNH}_{2}-\mathrm{MgH}_{2}\right)$. Int. J. Hydrogen Energy 2012, 37, 6646-6652. [CrossRef]

330. Wang, J.; Chen, P.; Pan, H.; Xiong, Z.; Gao, M.; Wu, G.; Liang, C.; Li, C.; Li, B.; Wang, J. Solid-Solid Heterogeneous Catalysis: The Role of Potassium in Promoting the Dehydrogenation of the $\mathrm{Mg}\left(\mathrm{NH}_{2}\right)_{2} / 2 \mathrm{LiH}$ Composite. ChemSusChem 2013, 6, 2181-2189. [CrossRef] [PubMed]

331. Li, C.; Liu, Y.; Ma, R.; Zhang, X.; Li, Y.; Gao, M.; Pan, H. Superior Dehydrogenation/Hydrogenation Kinetics and Long-Term Cycling Performance of $\mathrm{K}$ and $\mathrm{Rb}$ Cocatalyzed $\mathrm{Mg}\left(\mathrm{NH}_{2}\right)_{2}-2 \mathrm{LiH}$ system. ACS Appl. Mater. Interfaces 2014, 6, 17024-17033. [CrossRef]

332. Durojaiye, T.; Hayes, J.; Goudy, A. Rubidium Hydride: An Exceptional Dehydrogenation Catalyst for the Lithium Amide/Magnesium Hydride System. J. Phys. Chem. C 2013, 117, 6554-6560. [CrossRef]

333. Hayes, J.; Durojaiye, T.; Goudy, A. Hydriding and dehydriding kinetics of RbH-doped 2LiNH2/MgH2 hydrogen storage system. J. Alloy. Compd. 2015, 645, S496-S499. [CrossRef]

334. Durojaiye, T.; Hayes, J.; Goudy, A. Potassium, rubidium and cesium hydrides as dehydrogenation catalysts for the lithium amide/magnesium hydride system. Int. J. Hydrogen Energy 2015, 40, 2266-2273. [CrossRef]

335. Torre, F.; Valentoni, A.; Milanese, C.; Pistidda, C.; Marini, A.; Dornheim, M. Kinetic improvement on the $\mathrm{CaH}_{2}$-catalyzed $\mathrm{Mg}\left(\mathrm{NH}_{2}\right)_{2}+2 \mathrm{LiH}$ system. J. Alloy. Compd. 2015, 645, S284-S287. [CrossRef]

336. Liu, Y.; Li, C.; Li, B.; Gao, M.; Pan, H. Metathesis Reaction-Induced Significant Improvement in Hydrogen Storage Properties of the KF-Added $\mathrm{Mg}\left(\mathrm{NH}_{2}\right)_{2}-2 \mathrm{LiH}$ System. J. Phys. Chem. C 2013, 117, 866-875. [CrossRef]

337. Sun, F.; Yan, M.; Ye, J.; Liu, X.; Jiang, L. Effect of CO on hydrogen storage performance of KF doped $2 \mathrm{LiNH}_{2}$ $+\mathrm{MgH}_{2}$ material. J. Alloy. Compd. 2014, 616, 47-50. [CrossRef]

338. Li, C.; Liu, Y.; Yang, Y.; Gao, M.; Pan, H. High-temperature failure behaviour and mechanism of K-based additives in Li-Mg-N-H hydrogen storage systems. J. Mater. Chem. A 2014, 2, 7345-7353. [CrossRef]

339. Li, C.; Liu, Y.; Gao, M.; Pan, H. Understanding the role of $\mathrm{K}$ in the significantly improved hydrogen storage properties of a KOH-doped Li-Mg-N-H system. J. Mater. Chem. A 2013, 1, 5031-5036.

340. Liu, Y.; Yang, Y.; Zhang, X.; Li, Y.; Gao, M.; Pan, H. Insights into the dehydrogenation reaction process of a K-containing $\mathrm{Mg}\left(\mathrm{NH}_{2}\right)_{2}-2 \mathrm{LiH}$ system. Dalton Trans. 2015, 44, 18012-18018. [CrossRef]

341. Chotard, J.-N.; Tang, W.S.; Raybaud, P.; Janot, R. Potassium Silanide $\left(\mathrm{KSiH}_{3}\right)$ : A Reversible Hydrogen Storage Material. Chem. Eur. J. 2011, 17, 12302-12309. [CrossRef]

342. Tang, W.S.; Chotard, J.-N.; Raybaud, P.; Janot, R. Hydrogenation properties of KSi and NaSi Zintl phases. Phys. Chem. Chem. Phys. 2012, 14, 13319-13324. [CrossRef]

343. Tang, W.S.; Chotard, J.-N.; Janot, R. Syntheis of single phase LiSi by ball milling: Electrochemical behavior and hydrogenation properties. J. Electrochem. Soc. 2013, 160, A1232-1240. [CrossRef]

344. Tang, W.S.; Chotard, J.-N.; Raybaud, P.; Janot, R. Enthalpy-entropy compensation effect in hydrogen storage materials: Striking example of alkali silanides $\mathrm{MSiH}_{3}(\mathrm{M}=\mathrm{K}, \mathrm{Rb}, \mathrm{Cs})$. J. Phys. Chem. C 2014, 118, 3409-3419. [CrossRef] 
345. Kranak, V.F.; Lin, Y.C.; Karlsson, M.; Mink, J.; Norberg, S.T.; Haussermann, U. Structural and vibrational properties of Silyl $\left(\mathrm{SiH}_{3}{ }^{-}\right)$anion in $\mathrm{KSiH}_{3}$ and $\mathrm{RbSiH}_{3}$ : New insight into Si-H interactions. Inorg. Chem. 2015, 54, 2300-2309. [CrossRef] [PubMed]

346. Tang, W.S.; Dimitrievska, M.; Chotard, J.-N.; Zhou, W.; Janot, R.; Skripov, A.V.; Udovic, T.J. Structural and dynamical trends in alkali-metal silanides characterized by neutron-scattering methods. J. Phys. Chem. C 2016, 120, 21218-21227. [CrossRef]

347. Auer, H.; Kohlmann, H. In situ investigations on the formation and decomposition of $\mathrm{KSiH}_{3}$ and $\mathrm{CsSiH}_{3}$. Z. Anorg. Allg. Chem. 2017, 643, 945-951. [CrossRef]

348. Zhang, J.; Yan, S.; Qu, H.; Yu, X.F.; Peng, P. Alkali metal silanides $\alpha-\mathrm{MSiH}_{3}$ : A family of complex hydrides for solid-state hydrogen storage. Int. J. Hydrogen Energy 2017, 42, 12405-12413. [CrossRef]

349. Jain, A.; Miyaoka, H.; Ichikawa, T.; Kojima, Y. Tailoring the absorption-desorption properties of $\mathrm{KSiH}_{3}$ compound using nano-metals $(\mathrm{Ni}, \mathrm{Co}, \mathrm{Nb})$ as catalyst. J. Alloy. Compd. 2015, 645, 1441-1447. [CrossRef]

350. Janot, R.; Tang, W.S.; Clemencon, D.; Chotard, J.-N. Catalyzed $\mathrm{KSiH}_{3}$ as a reversible hydrogen storage material. J. Mater. Chem. A 2016, 4, 19045-19052. [CrossRef]

(C) 2018 by the authors. Licensee MDPI, Basel, Switzerland. This article is an open access article distributed under the terms and conditions of the Creative Commons Attribution (CC BY) license (http://creativecommons.org/licenses/by/4.0/). 